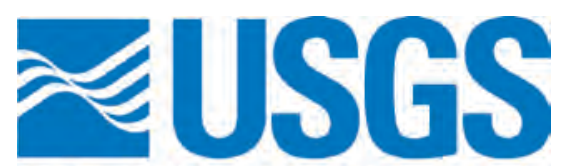

science for a changing world

Prepared in cooperation with the Absentee Shawnee Tribe of Oklahoma

Reconnaissance of Soil, Ground Water, and Plant Contamination at an Abandoned Oilfield-Service Site near Shawnee, Oklahoma, 2005-2006

Scientific Investigations Report 2007-5131 
Cover photograph shows the threading barn taken in June 2004 by the Absentee Shawnee Tribe, Office of Environmental Protection. Photograph was reproduced with permission of the Absentee Shawnee Tribe. 


\section{Reconnaissance of Soil, Ground Water, and Plant Contamination at an Abandoned Oilfield-Service Site near Shawnee, Oklahoma, 2005-2006}

By Shana L. Mashburn and S. Jerrod Smith

Prepared in cooperation with the Absentee Shawnee Tribe of Oklahoma

Scientific Investigations Report 2007-5131 


\section{U.S. Department of the Interior DIRK KEMPTHORNE, Secretary}

\section{U.S. Geological Survey \\ Mark D. Myers, Director}

\section{U.S. Geological Survey, Reston, Virginia: 2007}

For product and ordering information:

World Wide Web: http://www.usgs.gov/pubprod

Telephone: 1-888-ASK-USGS

For more information on the USGS — the Federal source for science about the Earth, its natural and living resources, natural hazards, and the environment:

World Wide Web: http://www.usgs.gov

Telephone: 1-888-ASK-USGS

Any use of trade, product, or firm names is for descriptive purposes only and does not imply endorsement by the U.S. Government.

Although this report is in the public domain, permission must be secured from the individual copyright owners to reproduce any copyrighted materials contained within this report.

Suggested citation:

Mashburn, S.L., and Smith, S.J., 2007, Reconnaissance of soil, ground water, and plant contamination at an abandoned oilfield-service site near Shawnee, Oklahoma, 2005-2006: U.S. Geological Survey Scientific Investigations Report 2007-5131, 91 p. 


\section{Contents}

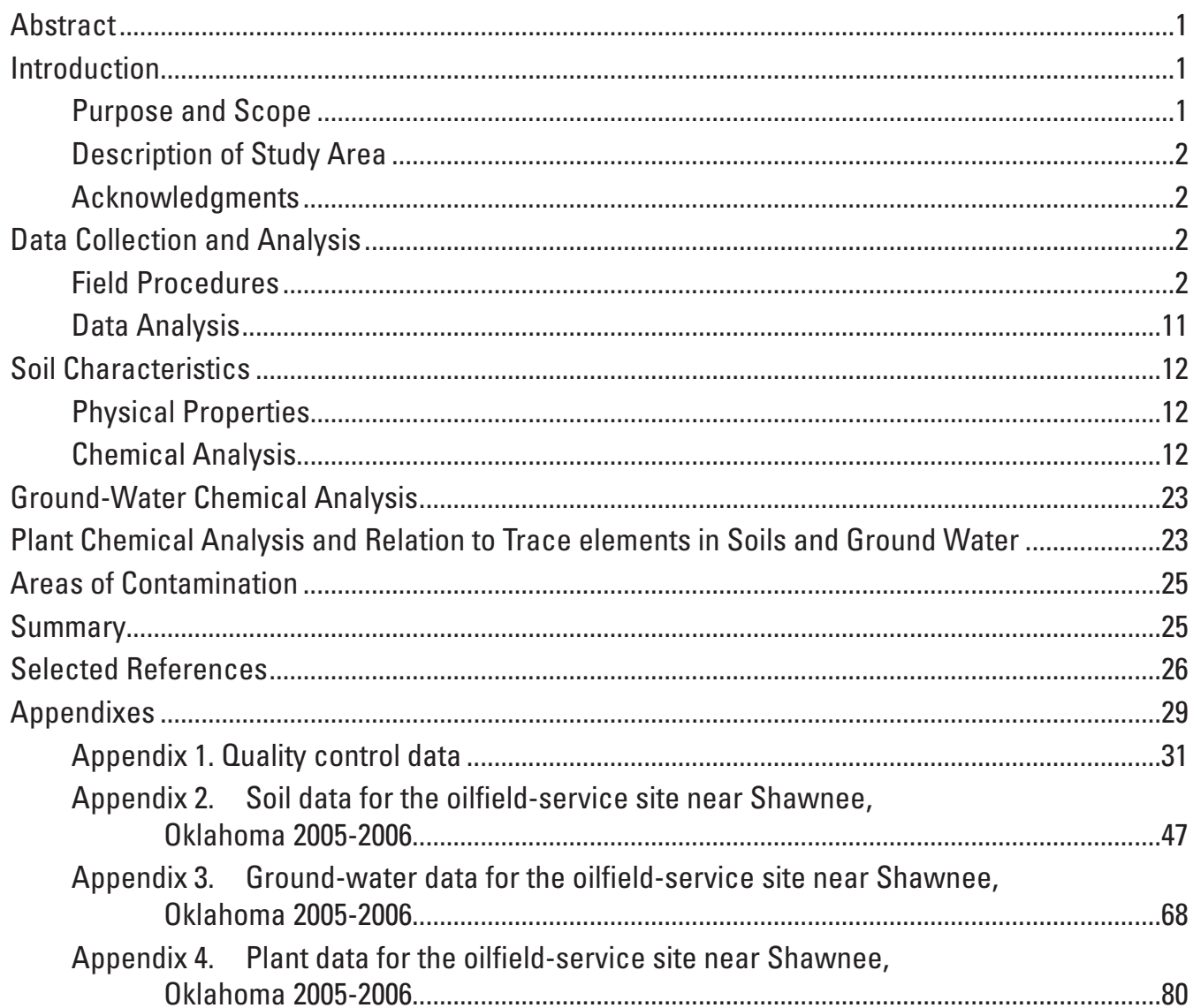

\section{Figures}

1. Map showing location of study area near Shawnee, Oklahoma .......................................3

2. Aerial photograph showing abandoned oilfield-service site near Shawnee, Oklahoma, 2005-2006 ......................................................................................................

3. Photographs showing buildings and debris on abandoned oifield-service site near Shawnee, Oklahoma, 2005-2006

4-5. Aerial photographs showing:

4. Locations of soil coring sites and installed wells (including existing supply well labeled Old Well) near Shawnee, Oklahoma, 2005-2006.

5. Locations of transects for initial plant survey and plant sampling sites near Shawnee, Oklahoma, 2005-2006

6. Diagram showing approximate range in soil textures found in the $A, B$, and $C$ horizons of soil cores collected from abandoned oilfield-service site near Shawnee, Oklahoma, 2005-2006

7. Descriptive log of soil textures found in soil core SS4 representative of well 1 near Shawnee, Oklahoma, 2005-2006 
8. Descriptive log of soil textures found in soil core SS1 representative of wells 2 and 5 near Shawnee, Oklahoma, 2005-2006.

9. Descriptive log of soil textures found in soil core SS7 representative of wells 3 and 4 near Shawnee, Oklahoma, 2005-2006.

10. Aerial photograph showing total trace-element and semivolatile organic compound concentrations in soil samples near Shawnee, Oklahoma, 2005-2006.

11. Boxplots showing trace-element concentrations in soil from abandoned oilfieldservice site near Shawnee, Oklahoma, 2005-2006 and soil and bedrock samples collected from Central Oklahoma aquifer in Pottawatomie County, Oklahoma, 1991.....18

12-13. Aerial photographs showing:

12. Trace elements and semivolatile organic compounds (SVOC) in ground-water samples near Shawnee, Oklahoma, 2005-2006.

13. Total trace-element concentrations in plant samples near Shawnee, Oklahoma, 2005-2006

\section{Tables}

1. Percent coverages of plants in Open Grassland Zones and Dense Covered Zones at the abandoned oilfield-service site near Shawnee, Oklahoma, 2005.

2. Summary table for U.S. Environmental Protection Agency, Region 6, Human Health Medium-Specific screening level exceedances

3. Ground-water levels measured in wells near Shawnee, Oklahoma, 2005-2006.

4. Quality-control soil samples collected from oilfield-service site near Shawnee, Oklahoma 2005-2006.

5. Quality-control ground-water samples collected from oilfield-service site near Shawnee, Oklahoma 2005-2006.

6. Quality-control plant samples collected from oilfield-service site near Shawnee, Oklahoma 2005-2006. 


\section{Conversion Factors}

\begin{tabular}{|c|c|c|}
\hline Multiply & By & To obtain \\
\hline \multicolumn{3}{|c|}{ Length } \\
\hline inch (in.) & 2.54 & centimeter $(\mathrm{cm})$ \\
\hline foot $(\mathrm{ft})$ & 0.3048 & meter $(\mathrm{m})$ \\
\hline mile (mi) & 1.609 & kilometer (km) \\
\hline \multicolumn{3}{|c|}{ Area } \\
\hline acre & 4,047 & square meter $\left(\mathrm{m}^{2}\right)$ \\
\hline
\end{tabular}

\begin{tabular}{lll}
\hline \multicolumn{1}{c}{ Multiply } & \multicolumn{1}{c}{ By } & To obtain \\
\hline & \multicolumn{1}{c}{ Length } \\
millimeter (mm) & 0.03937 & inch (in.) \\
meter $(\mathrm{m})$ & 3.281 & foot (ft) \\
meter $(\mathrm{m})$ & 1.094 & yard (yd) \\
\hline \multicolumn{3}{c}{ Mass } \\
\hline milligram (mg) & 0.00003527 & ounce (oz) \\
kilogram $(\mathrm{kg})$ & 2.205 & pound (lb)
\end{tabular}

Temperature in degrees Celsius $\left({ }^{\circ} \mathrm{C}\right)$ may be converted to degrees Fahrenheit $\left({ }^{\circ} \mathrm{F}\right)$ as follows:

${ }^{\circ} \mathrm{F}=\left(1.8 \times{ }^{\circ} \mathrm{C}\right)+32$

Temperature in degrees Fahrenheit $\left({ }^{\circ} \mathrm{F}\right)$ may be converted to degrees Celsius $\left({ }^{\circ} \mathrm{C}\right)$ as follows:

${ }^{\circ} \mathrm{C}=\left({ }^{\circ} \mathrm{F}-32\right) / 1.8$

Vertical coordinate information is referenced to the North American Vertical Datum of 1988

(NAVD 88).

Horizontal coordinate information is referenced to the North American Datum of 1983 (NAD 83).

Altitude, as used in this report, refers to distance above the vertical datum.

Specific conductance is given in microsiemens per centimeter at 25 degrees Celsius $(\mu \mathrm{S} / \mathrm{cm}$ at $\left.25^{\circ} \mathrm{C}\right)$.

Concentrations of chemical constituents in soil are given either in milligrams per kilogram (mg/ $\mathrm{kg}$ ) or micrograms per kilogram $(\mu \mathrm{g} / \mathrm{kg})$. Milligrams per kilogram $(\mathrm{mg} / \mathrm{kg})$ is equivalent to parts per million $(\mathrm{ppm})$ and micrograms per kilogram $(\mu \mathrm{g} / \mathrm{kg})$ is equivalent to parts per billion $(\mathrm{ppb})$ for constituent concentrations in soil.

Concentrations of chemical constituents in water are given either in milligrams per liter $(\mathrm{mg} / \mathrm{L})$ or micrograms per liter $(\mu \mathrm{g} / \mathrm{L})$. Milligrams per liter $(\mathrm{mg} / \mathrm{L})$ is equivalent to parts per million $(\mathrm{ppm})$ and micrograms per liter $(\mu \mathrm{g} / \mathrm{L})$ is equivalent to parts per billion $(\mathrm{ppb})$ for constituent concentrations in water.

Concentrations of chemical constituents in plants are given either in parts per million (ppm), parts per billion (ppb), or percent (\%). Parts per million (ppm) is equivalent to milligrams per kilogram $(\mathrm{mg} / \mathrm{kg})$, parts per billion $(\mathrm{ppb})$ is equivalent to micrograms per kilogram $(\mu \mathrm{g} / \mathrm{kg})$, and percent $(\%)$ is equivalent to 10,000 parts per million (ppm). 
Laboratory reporting level (LRL) is generally equal to twice the yearly determined long-term method detection level. The LRL controls false negative error. The probability of falsely reporting a nondetection for a sample that contained an constituent at a concentration equal to or greater than the LRL is predicted to be less than or equal to 1 percent (Childress and others, 1999). 


\title{
Reconnaissance of Soil, Ground Water, and Plant Contamination at an Abandoned Oilfield-Service Site near Shawnee, Oklahoma, 2005-2006
}

\author{
By Shana L. Mashburn and S. Jerrod Smith
}

\section{Abstract}

The U.S. Geological Survey, in cooperation with the Absentee Shawnee Tribe of Oklahoma, began a reconnaissance study of a site in Pottawatomie County, Oklahoma, in 2005 by testing soil, shallow ground water, and plant material for the presence of trace elements and semivolatile organic compounds. Chemical analysis of plant material at the site was investigated as a preliminary tool to determine the extent of contamination at the site.

Thirty soil samples were collected from 15 soil cores during October 2005 and analyzed for trace elements and semivolatile organic compounds. Five small-diameter, polyvinyl-chloride-cased wells were installed and groundwater samples were collected during December 2005 and May 2006 and analyzed for trace elements and semivolatile organic compounds. Thirty Johnsongrass samples and 16 Coralberry samples were collected during September 2005 and analyzed for 53 constituents, including trace elements.

Results of the soil, ground-water, and plant data indicate that the areas of trace element and semivolatile organic compound contamination are located in the shallow (A-horizon) soils near the threading barn. Most of the trace-element concentrations in the soils on the study site were either similar to or less than trace-element concentrations in background soils. Several trace elements and semivolatile organic compounds exceeded the U.S. Environmental Protection Agency, Region 6, Human Health Medium-Specific Screening Levels 2007 for Tap Water, Residential Soils, Industrial Indoor Soils, and Industrial Outdoor Soils.

There was little or no correlation between the plant and soil sample concentrations and the plant and ground-water concentrations based on the current sample size and study design. The lack of correlation between trace-element concentrations in plants and soils, and plants and ground water indicate that plant sampling was not useful as a preliminary tool to assess contamination at the study site.

\section{Introduction}

The state of Oklahoma has a well-known history of oil and gas production beginning in the late 1800s (Oklahoma Energy Resources Board, 2006). Oilfield-service sites were an integral part of the oil and gas industry and used for storage and maintenance of oilfield equipment. The Absentee Shawnee Tribe of Oklahoma was working to reclaim an oilfieldservice site near Shawnee, Oklahoma and needed to determine the nature and extent of contamination to aid clean-up efforts. The oilfield service-site contained production storage tanks, production pipe, and warehouses and other buildings that were used to clean and cut production pipe. Wastes left behind on the oilfield-service site in Shawnee, Oklahoma consisted of pipes, cuttings from pipe threading, hydraulic fluid, oils, and solvents. The U.S. Geological Survey (USGS), in cooperation with the Absentee Shawnee Tribe of Oklahoma, began a reconnaissance study of a site in Pottawatomie County (fig. 1) in 2005 by testing soil, shallow ground water, and plant material for the presence of trace elements and semivolatile organic compounds (SVOCs). The objectives of the study were to (1) summarize soil, ground-water, and plant data collected for the reconnaissance study, (2) determine if trace-element concentrations from this study were similar to background concentrations in the area, (3) report exceedances of the U.S. Environmental Protection Agency (USEPA), Region 6, Human Health Medium-Specific Screening Levels 2007 for Tap Water, Residential Soils, Industrial Indoor Soils, and Industrial Outdoor Soils, and (4) investigate chemical analysis of plant material as a preliminary tool to determine the extent of contamination at the site. The results of this study will support the Absentee Shawnee Tribe clean-up efforts on the site.

\section{Purpose and Scope}

The purpose of this report is to present the results of the soil, ground-water, and plant analyses at the abandoned oilfield-service site and compare them to the U.S. Environmental Protection Agency screening level criteria for human 
health. The utility of plant material analysis as a surrogate for soil and ground-water contamination with trace elements also is discussed. The scope of this report was limited to a specific study area of approximately 20 acres and was restricted to analysis of trace elements and SVOCs present in soil, shallow ground water, and plants. The scope of this report also was confined by the period of data collection from September 2005 to May 2006.

\section{Description of Study Area}

The abandoned oilfield-service site is approximately 20 acres in size and located south of Shawnee, Oklahoma, near an upland terrace south of the North Canadian River (fig. 1). A small intermittent creek is located in the center of the property that drains to Squirrel Creek and eventually the North Canadian River. The site is underlain by the Oscar Group, a red-brown to gray shale and orange-brown fine-grained, crossbedded sandstone of Pennsylvanian age (Bingham and Moore, 1975) ranging from 570 to 940 feet in thickness (Christenson and others, 1992). Parkhurst and others (1996) refer to the Oscar Group as the Chase, Council Grove, and Admire Groups of Permian age, which composes part of the Central Oklahoma aquifer (COA). The COA is used to supply water for municipal, domestic, industrial, and agricultural needs (Tortorelli, 2004).

Soils were generally silt loam of the Port and Chickasha soil series (Soil Conservation Service, 1977). The Port series consist of very deep, well drained, moderately permeable flood plain soils that formed in calcareous loamy alluvium of recent age. Soil cores on the site contained some terrace deposits, but those deposits were very thin and discontinuous. Native vegetation on Port soils was tall grasses with a canopy of pecan, black walnut, bur oak, and eastern cottonwood trees. The Chickasha series consists of deep, well drained, moderately permeable soils that formed in material weathered from sandstone of Permian age. Native vegetation on the Chickasha soils was tallgrass prairie. Precipitation near Shawnee, Oklahoma, is about 35 to 40 inches annually (Oklahoma Climatological Survey, 2002). Rainfall is most abundant from March to May and least abundant from December to February (Oklahoma Climatological Survey, 2002).

Local hydrology at the site consists of shallow semipermeable unconsolidated material (silty clay loam) that has limited hydrologic connection to the intermittent creek and the Oscar Group bedrock. Ground water in the shallow unconsolidated material is present under perched conditions. A tight mudstone at the base of the unconsolidated material confines the bedrock aquifer and limits the potential for surface and subsurface contaminants to be transported to the bedrock aquifer. Shallow ground water in the unconsolidated material potentially drains to the creek. Surface and subsurface contamination could potentially enter the creek and travel downstream. No flow was observed in the intermittent creek during dry periods of the year.
The site was used as a pipe and supply yard for local oilfield production activities from the early 1960s to the mid1990s (Renee Hood, Absentee Shawnee Tribe, oral commun., 2005). Activities on the site included storage of several types of oilfield production pipes, separators and production oil storage tanks; cleaning the pipes and equipment, and cutting new threads on the pipes. Buildings on the site were used for vehicle maintenance, pipe threading, storage, and offices (fig. 2 ). The site contained piles of debris, including solid wastes, metal shavings, lead-acid batteries, and metal barrels containing hydraulic fluids and solvents (fig. 3).

\section{Acknowledgments}

The authors wish to thank the Absentee Shawnee Tribe of Oklahoma, Office of Environmental Protection staff for their assistance in the study. Renee Hood coordinated all project activities; Roger Anderson, Mark Williams, and Kevin Smith provided assistance for field activities and data collection. Sincere thanks to Lacy Jo Burgess, University of Oklahoma student, for plant species identification and percent coverage of the site. The authors thank Shea Clark Smith of Minerals Exploration and Environmental Geochemistry Laboratory (MEG Labs) for his knowledge and advice on biogeochemistry sampling. Additional thanks to Jason Masoner, U.S. Geological Survey, for assisting with data collection.

\section{Data Collection and Analysis}

Most samples for this study were collected from the east side of the study area. The east side contained apparent subsurface contamination based on previous site assessments done by the Absentee Shawnee Tribe (Renee Hood, Absentee Shawnee Tribe, oral commun., 2005) The west side of the study area appeared to contain mostly above ground debris. Soil cores were collected with a Geoprobe. Five wells were installed to collect ground-water samples and to measure water levels. Johnsongrass and Coralberry plant material samples were collected from the site for chemical analysis.

\section{Field Procedures}

Thirty soil samples were collected from 15 soil cores. The cores were collected by use of a truck-mounted Geoprobe during October 2005. A Geoprobe is a hydraulically powered sampling and logging tool that uses both static force and percussion to advance into the ground. Soil cores were collected from land surface to the point of refusal, which was assumed to be the soil-bedrock interface. Soil cores were retrieved from 1.5 -inch diameter by 48 inches long plastic sleeves. Ten coring locations were near previously collected plant sample sites for investigation of possible correlation between plant and soil trace-element concentrations. Five coring locations were 


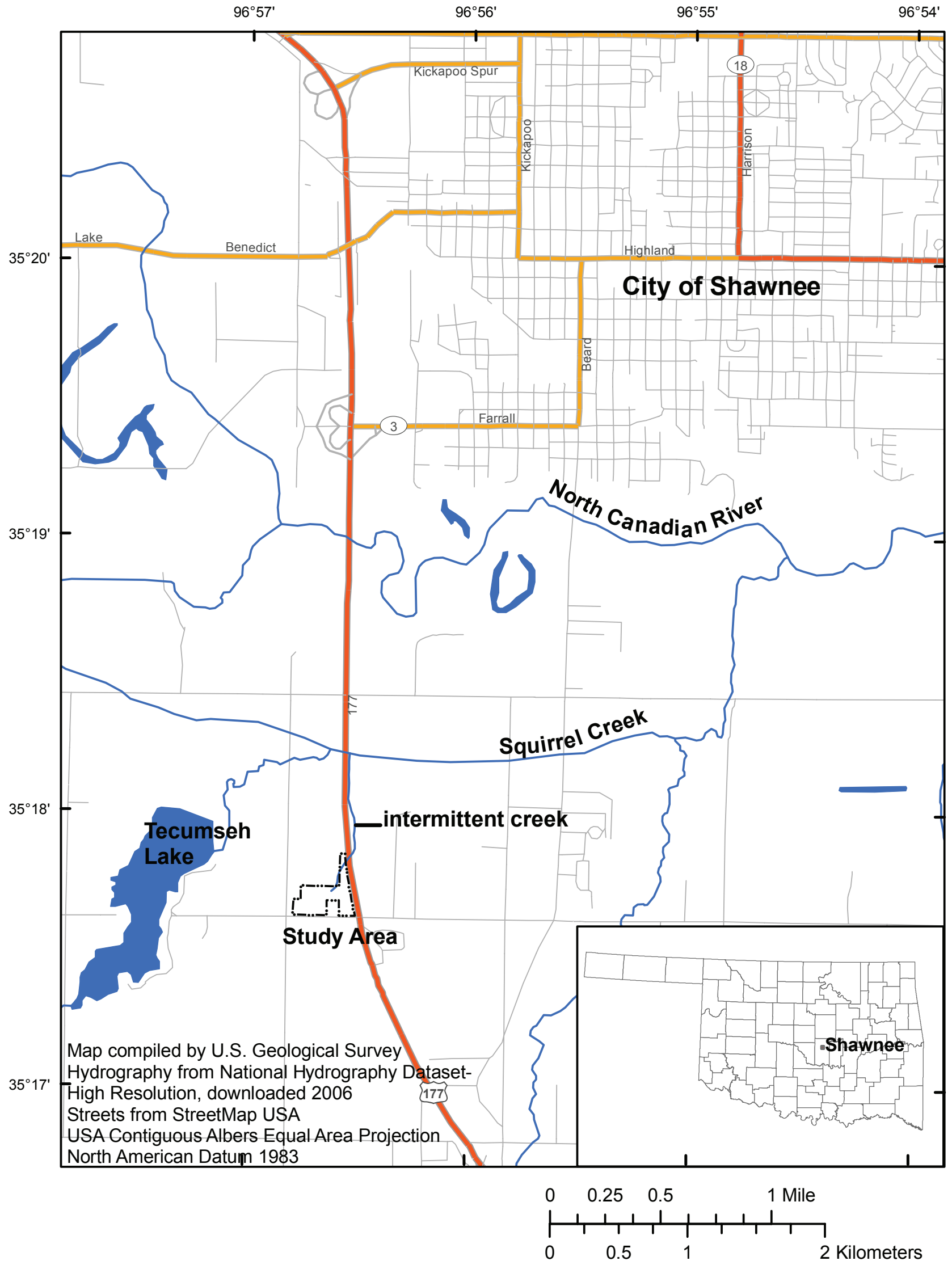

Figure 1. Location of study area near Shawnee, Oklahoma. 


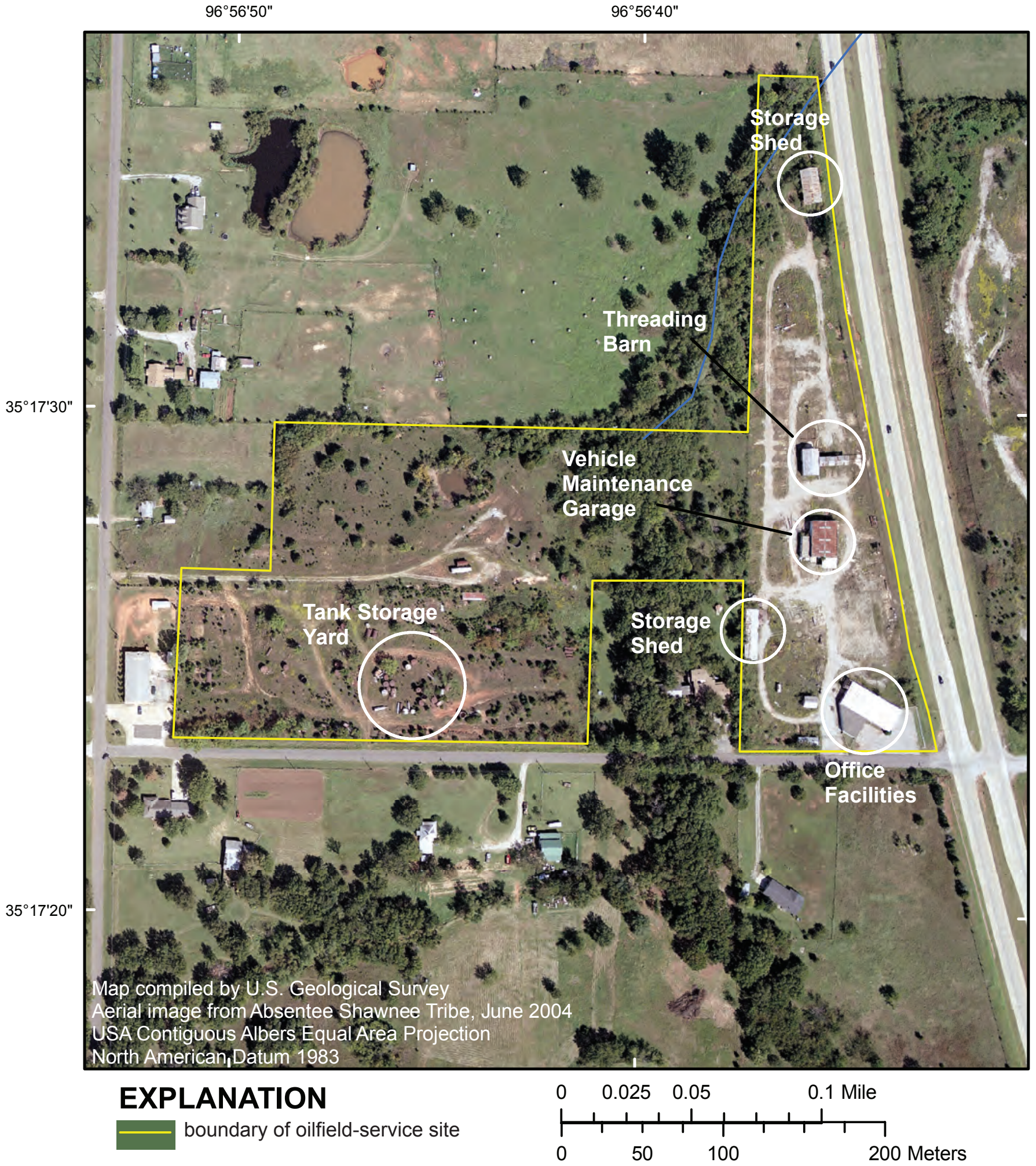

Figure 2. Abandoned oilfield-service site near Shawnee, 0klahoma, 2005-2006. 

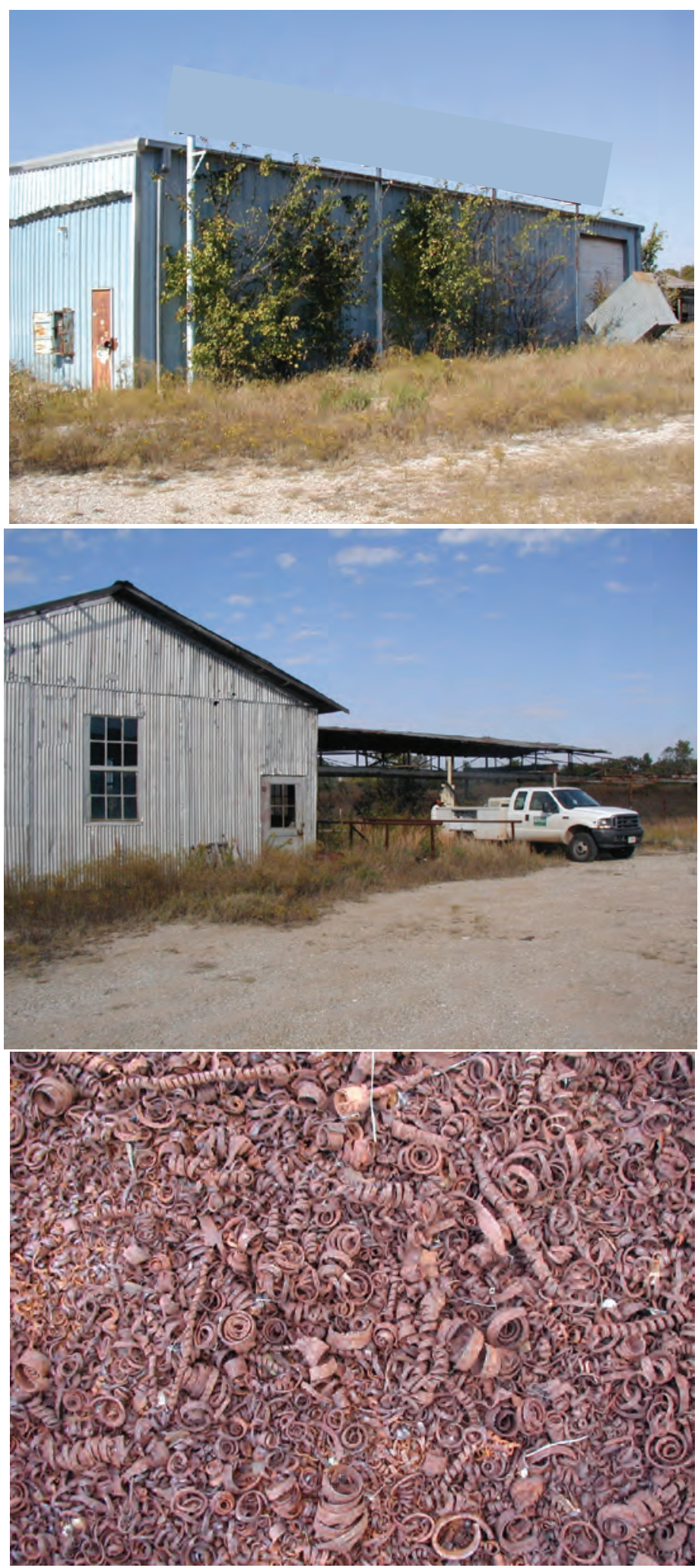

Figure 3. Buildings and debris on abandoned oilfield-service site near Shawnee, Oklahoma, 2005-2006. (Photographs taken by S. Jerrod Smith, U.S. Geological Survey.) 
selected in poorly vegetated areas. Coring locations also were dependent on apparent surface contamination and by accessibility (fig. 4). The cores were processed at a field laboratory on site. Two parallel cuts along the length of the core sleeve were made with two parallel stainless steel hook blades to expose the 1.5-inch soil core for descriptions of color and texture. The parallel cuts penetrated only the plastic core sleeve and not the material inside the core. The cores were described to identify soil horizons for sampling and to provide general information regarding presence of ground water and possible contaminants. After the cores were described, two soil samples were collected from each core for a total of 30 soil samples. Each soil sample was collected using a decontaminated plastic spoon to prevent cross-contamination between soil samples. Each sample was collected from the center of the core, ranging from 3 to 6 inches of core length, to prevent contact of soil sample with any possible contaminant residue on the core sleeve. Sixteen ounces of core material were collected into two 8-ounce glass containers for each sample and shipped overnight. Soil samples were collected from the B and C soil horizons to observe possible leaching into the substratum. The $\mathrm{C}$ horizon was usually below the water table and where the well screens were installed. If there was apparent contamination in the core, samples were collected from the contaminated zone and from an uncontaminated zone, which were not necessarily from the B and C soil horizons. Examples of apparent contamination include petroleum odor, metal shavings, and soil with color and consistency of tar. Soil samples were labeled with an identifier corresponding to the sequential order of coring and a letter representing the soil horizon from which the sample was collected. If more than one sample was collected from a soil horizon, a number followed the soil horizon letter to indicate the sequence of the samples (example B1 and B2). Soil samples were shipped to Severn Trent Laboratories, Arvada, Colorado, for analysis of trace elements using U.S. Environmental Protection Agency methods 6010B and 6020, and for SVOCs using method $8270 \mathrm{C}$. Three replicate soil samples also were submitted to assess laboratory analytical error and sample variation, and are discussed in appendix 1.

Five 0.5-inch diameter, polyvinyl-chloride(pvc)-cased wells were installed with a Geoprobe to collect ground-water samples. The water table was identified by apparent water saturation in the soil cores. Well locations were selected near the creek because shallow ground water was not found in the upland areas of the site (fig. 4). Wells ranged in total depth from 15 to 24 feet, with a 3-foot screen attached to the end of the casing. Water samples were collected during December 2005 and May 2006 for analysis of trace elements and SVOCs. Three well volumes were purged prior to sampling the shallow wells. Ground water was sampled from the shallow wells using a peristaltic pump and C-flex tubing that was replaced between wells. Ground-water samples were labeled with an identifier that corresponds to the well from which the samples were collected. Sampling dates were chosen to observe possible seasonal differences in trace element and SVOC concentrations. The least amount of rain falls in Oklahoma from
December to February (Oklahoma Climatological Survey, 2002). During this time the plants are dormant and evapotranspiration is minimal. The greatest amount of rain falls in Oklahoma from March to May when the plants are more active and evapotranspiration is high.

An existing water-supply well on the site (referred to in this report as the Old Well) was sampled on December 2005 and May 2006 for analysis of trace elements and SVOCs (fig. 4). Records about construction information are not available for the Old Well. The depth of the Old Well was approximately greater than 250 feet. The depth was determined from the depth of the pump after the pump was pulled from the well. This old well was most likely completed in the Oscar Group (Chase, Council Grove, and Admire Groups). A waterquality sample was collected from water in the Old Well to compare deep and shallow water quality in the study area. The Old Well was not purged because of logistical considerations for disposal of any purged water; therefore, a grab sample was collected at the water surface using a Teflon bailer.

All ground-water samples were analyzed at the USGS National Water Quality Laboratory, Lakewood, Colorado, for laboratory schedules 2703 (dissolved trace elements) and 1383 (SVOCs). Quality control for the ground-water samples consisted of one equipment blank, one field blank, and two replicate environmental samples (appendix 1). Water levels were measured with an electric tape in the installed wells and the Old Well during January 2006 and May 2006 at the time of sampling. Water levels also were measured during December 2005 and March 2006 to determine any seasonal differences in water levels.

An initial survey was conducted during June 2005 to identify the plant species available for sampling on the site. Individual plants were identified along nine east-west 20 -meter transects across the site (fig. 5). Percent coverage of each plant species was calculated for each transect. The survey indicated there were two distinct vegetation zones or groups of species in the study area. One group prefers direct sunlight (open grassland) and the other group prefers shade (dense covered). Ideally, only one species of plant would be sampled across the site; although the initial survey proved this was not possible. The open grassland zones were dominated by Johnsongrass (Sorghum halepense) and Goldenrod (Solidago spp.). The dense covered zones were dominated by Coralberry (Symphoricarpos orbiculatus) and Saw Greenbrier (Smilax bonanox L.) (table 1). Open grassland zones cover about 65 percent of the site and dense covered zones cover about 35 percent of the site. Johnsongrass was selected for sampling in the open grassland zones, and Coralberry was selected for sampling in the dense covered zones. These perennial plants were selected for sampling because of the relatively high amounts of water used for growth, and abundance in the study area. Thirty Johnsongrass samples and 16 Coralberry samples were collected during September 2005. Plant sample locations (fig. 5) were determined based on abundance of species at each location in order to obtain enough plant material for analysis. Each plant sample was collected using nitrile gloves and decontaminated 


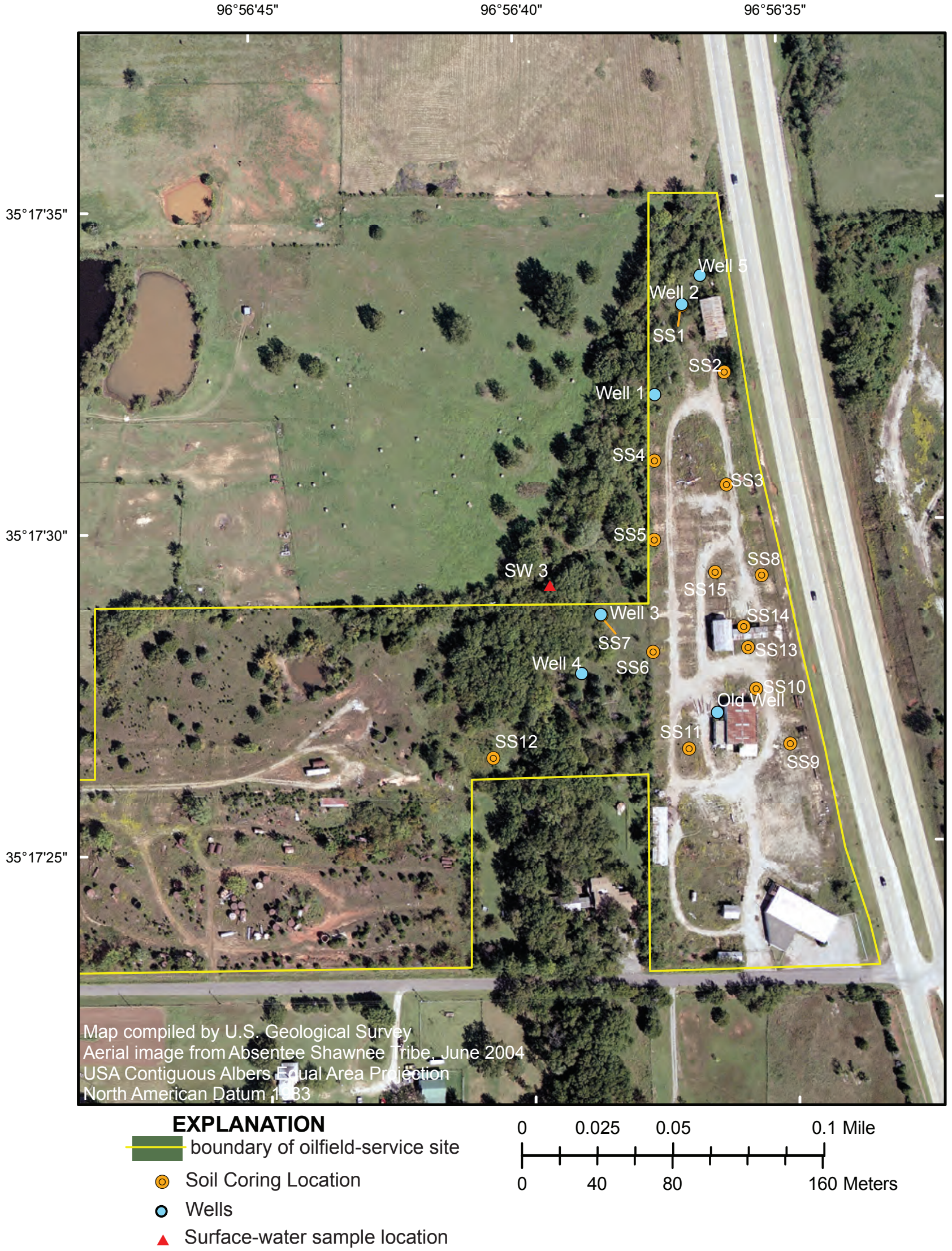

Figure 4. Locations of soil coring sites and installed wells (including existing supply well labeled Old Well) near Shawnee, Oklahoma, 2005-2006. 


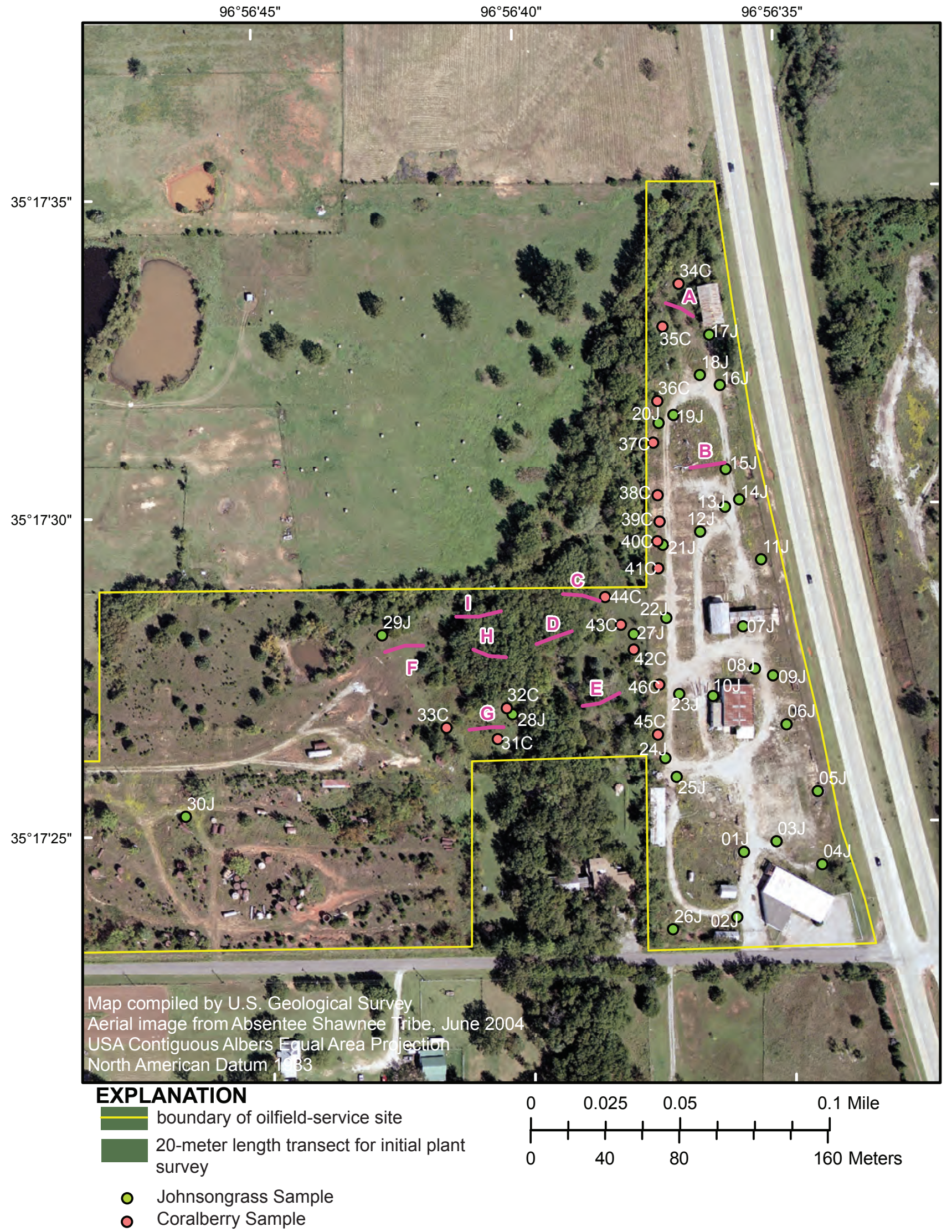

Figure 5. Locations of transects for initial plant survey and plant sampling sites near Shawnee, 0klahoma, $2005-2006$. 


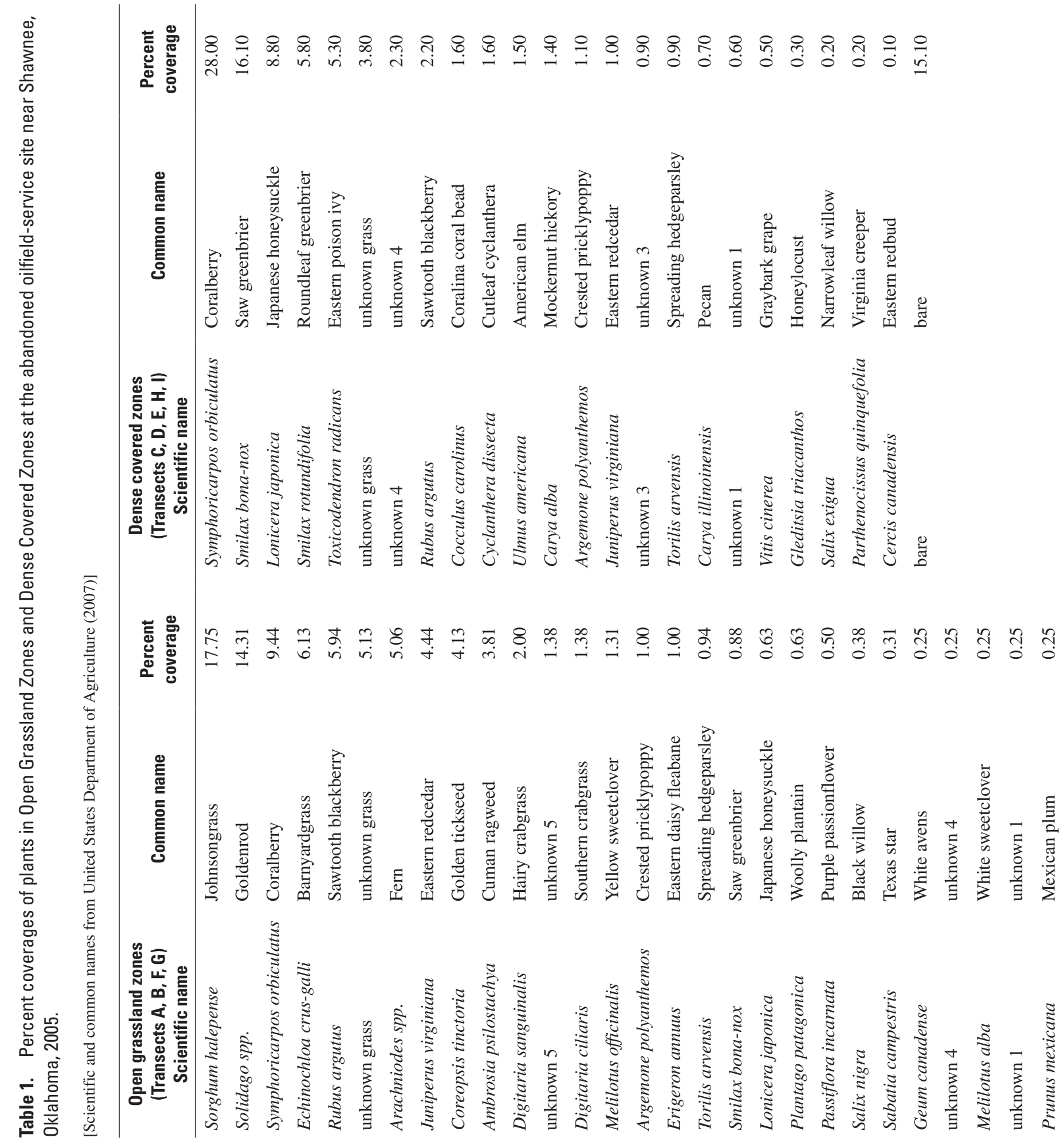




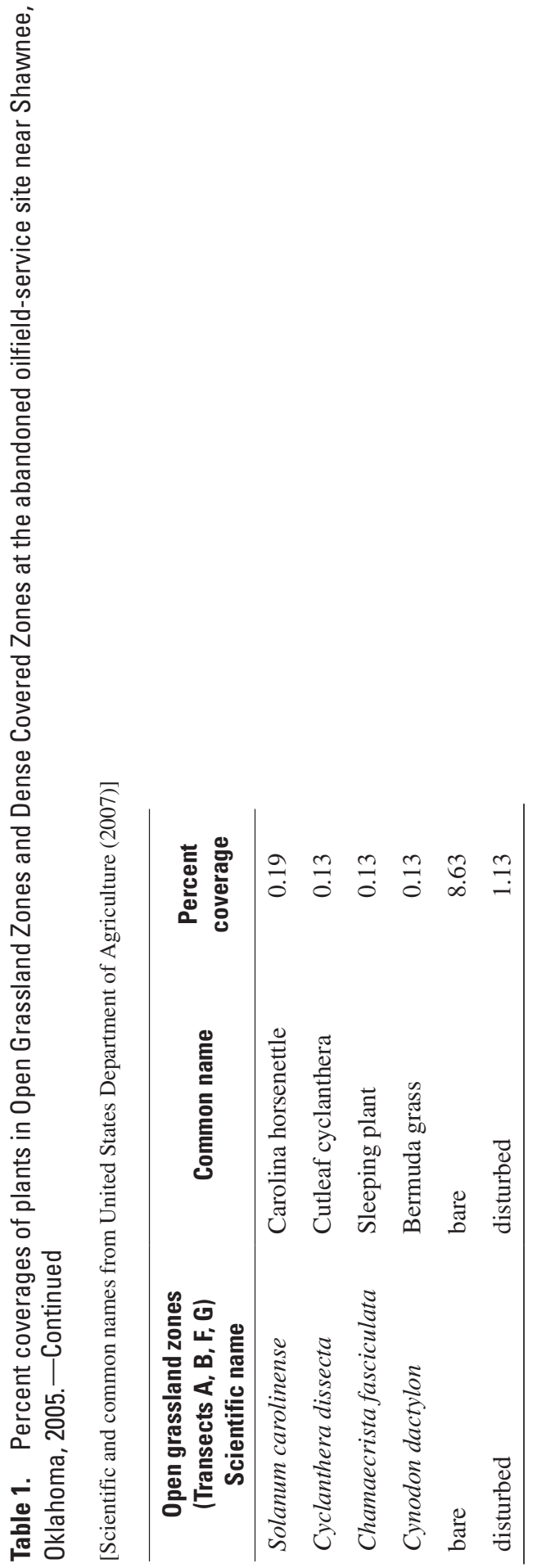


stainless steel scissors to prevent cross-contamination between samples. Johnsongrass was collected by cutting with scissors the main stem an inch above the soil. Leaves and stems were then folded to fit into a cloth sample bag. Coralberry samples were collected by cutting with scissors the most recent growth where it joined the main stem and placing leaves, berries, and stems into a cloth sample bag.

Each plant sample was labeled with an identifier corresponding to sequential order of sampling and the letter $\mathrm{J}$ or $\mathrm{C}$, indicating Johnsongrass or Coralberry sample. Cloth sample bags were placed in a cardboard box and shipped to Minerals Exploration and Environmental Geochemistry Laboratories (MEG Labs), Carson City, Nevada. The samples were dried and washed in tap water at the lab to remove any dirt and foreign debris. Leaves and stems of Johnsongrass samples were extracted for chemical analysis. Only the leaves of the Coralberry samples were extracted for chemical analysis. All plant samples were analyzed for 53 constituents, including trace elements, by inductively coupled plasma-mass spectrometry. Quality control for the plant samples consisted of six replicate environmental samples (appendix 1).

Plant tissue analysis has been used as a tool in mineral exploration or prospecting since the early 1930s (Rose and others, 1979). The science behind this tool is based on the ability of plants to uptake constituents from ground water. Meinzer (1923) defined a phreatophyte as a plant that habitually obtains its water supply from the zone of saturation, either directly or through the capillary fringe. Phreatophytes have been shown to be general indicators of ground-water quality (Meinzer, 1927). Although the plants sampled in this study are not categorized as phreatophytes, both species use relatively high amounts of water for growth (U.S. Department of Agriculture, 2007). The phreatophytes that were present on the site did not abundantly cover the study area; therefore phreatophytes were not used for sampling. Plant tissue analysis has been used more recently to identify areas of environmental contamination. Erdman and Christenson (2000) correlated boron, sodium, bromine, and strontium concentrations in cottonwood leaves to constituent concentrations in ground water and used the relations to determine the extent of a landfill leachate plume. Erdman and others (2003) determined the extent of a contamination plume near a silver mining district by identifying the anomalous presence of zinc and cadmium in willow leaves.

\section{Data Analysis}

Data analysis methods used in this study consist of graphical, statistical, and geospatial techniques. Many detections of trace elements in soil samples occurred, because trace elements occur naturally in soils at detectable concentrations (Smith and others, 2005). Tukey's standard boxplots (Helsel and Hirsch, 2002) were used to display the summary statistics of trace elements in soil samples. Most of the soil samples contained no detectable SVOCs, because SVOCs do not occur naturally in soils; therefore, any soil sample with a reported value was considered greater than background. Trace element and SVOC concentrations were totaled to obtain a total concentration per sample.

Trace-element concentrations in soil samples from this study were statistically compared to trace-element concentrations in soils from a study of the COA (Christenson and others, 1991) that served as an indicator of background concentrations. Trace-element concentrations in soils from this study also were statistically compared to trace-element concentrations in rock samples from the COA study to determine if the trace-element concentrations in the soils were similar to the underlying Oscar Group (Chase, Council Grove, and Admire Groups). Statistical comparisons were performed using the Wilcoxon (Mann-Whitney) rank sum test with a 95 percent confidence interval. The Wilcoxon rank sum test is a nonparametric test that determines if the medians of two independent data groups are statistically different. Data were censored to a single value less than the highest reporting level for each constituent to account for multiple reporting levels in the two data sets (Helsel, 2005). The tie correction equation was used to account for multiple tied ranks in the data as suggested by Helsel and Hirsch (2002).

Most of the trace elements and SVOCs were not detectable in ground-water samples. Trace-element concentrations in ground water from this study were compared to previous ground-water data in the USGS National Water Information System database (http://waterdata.usgs.gov/ok/nwis) from the shallow bedrock aquifers in Pottawatomie County to determine if the trace-element concentrations from this study were similar to background concentrations.

The soil and ground-water analytical results were compared to the U.S. Environmental Protection Agency, Region 6, Human Health Medium-Specific Screening Levels 2007 for Tap Water, Residential Soils, Industrial Indoor Soils, and Industrial Outdoor Soils (U.S. Environmental Protection Agency, 2006). This comparison provided a baseline to determine the areas for clean-up efforts.

As in soil samples, trace elements occur naturally in plant tissue at detectable concentrations (Shea Clark Smith, MEG Labs, oral commun., 2005). The laboratory reported detectable concentrations in most of the plant samples. Johnsongrass and Coralberry samples were separated into two data sets for analysis because it was apparent that trace element uptake varied among the two species. Boxplots were used to display the summary statistics of trace elements in plant samples.

Plant data were compared to the soil data using the Spearman rho or Spearman rank correlation coefficient. The Spearman rank correlation coefficient is a nonparametric statistical test that can identify both linear and nonlinear relations between two populations of data. A 95 percent confidence interval was used to determine if significant correlation existed between the plant and soil trace-element concentrations. Plant data were compared to the ground-water data by a geospatial comparison because of the small set of ground-water data. The possible correlation of plant data to ground-water data would 
indicate plants take up constituents from the shallow ground water. The possible correlation of plant data to soil data would indicate that the soil plays a role in the uptake of constituents by plants. Any correlation between these data would indicate that plant sampling could be used as a preliminary tool to assess contamination.

\section{Soil Characteristics}

Soil characteristics are important to understanding the possible migration pathways for contaminants. Clays typically act as barriers and sands act as conduits to ground water and solute migration.

\section{Physical Properties}

The 15 soil cores ranged in depth from 45 to 288 inches. The soil-bedrock interface was often difficult to distinguish because local bedrock was poorly consolidated. Soil texture was determined from the feel of fresh, moist core samples, and descriptions in the Soil Survey of Pottawatomie County (Soil Conservation Service, 1977). Texture generally became finer with depth in the soil profile, typically ranging from silt loam or loam near the surface (A horizon) to silty clay or silty clay loam at depth (B and C horizons) (fig. 6). Where undisturbed, the A horizon was usually dark or light brown with fine granular structure. $\mathrm{B}$ and $\mathrm{C}$ horizons were usually red-brown to red with fine to medium prismatic structure, reflecting the increase in percent clay with depth. Soil color terms are subjective and were used only as a means of differentiating between zones in each individual core. The descriptions should not be considered as standardized or comparable between cores. The color and composition of the $\mathrm{C}$ horizon varied widely depending on the characteristics of the parent material. Green-gray iron reduction spots and sandstone rock fragments, which were derived from the bedrock, were present near the base of some cores. The $\mathrm{C}$ horizon was generally composed of thick hard clay, but sandy zones were identified in several cores in the $\mathrm{C}$ horizon. Small carbonate nodules and unidentified black spots, possibly manganese, were often distributed throughout the B and $\mathrm{C}$ horizons. The diameter of these features was generally .05 to 0.5 inches and appeared to be slightly larger below the water table in the deeper sections of the profile.

Soil core SS4 was representative of the soil profile at well 1 (fig. 7). Soil core SS1 was representative of the soil profile at wells 2 and 5 (fig. 8). Soil core SS7 was representative of the soil profile at wells 3 and 4 (fig. 9). The soil profile in SS1 was generally coarser and more developed than the profile in SS7. This was possibly because SS1 was located closer to Squirrel Creek and the North Canadian River floodplain. Saturated zones were identified at a depth of 16 feet from land surface in SS7 and at a depth of about 20 feet from land surface in SS1.

\section{Chemical Analysis}

Trace-element concentrations were totaled for seven trace elements (cadmium, chromium, copper, lead, nickel, silver, and zinc) to determine total trace element concentration per sample (raw data in appendix 2). Soil sample SS15-A contained a total trace element concentration of 964,563 micrograms per kilogram $(\mu \mathrm{g} / \mathrm{kg})$ for the seven trace elements. Soil sample SS13-A contained a total trace element concentration of $625,930 \mu \mathrm{g} / \mathrm{kg}$ for the seven trace elements (fig. 10).

The detectable SVOC concentrations were totaled to determine a total SVOC concentration per sample (raw data in appendix 2). Soil sample SS13-A had the most SVOC detections of all the sites, and contained 17 different compounds with a total SVOC concentration of $151,300 \mu \mathrm{g} / \mathrm{kg}$ (fig. 10). Soil sample SS4-A contained 11 SVOCs with a total SVOC concentration of $2,242 \mu \mathrm{g} / \mathrm{kg}$.

A study of the COA (Mosier and others, 1991) analyzed outcropping rocks and soils from the B horizon for 44 elements. The purpose of the COA study was to understand rock-water interaction through analysis of chemistry, hydrology, and geochemical analysis of solid constituents (not water) within the aquifer. Trace-element concentrations in COA soil and bedrock samples from Pottawatomie County were compared to concentrations from this study (fig. 11). Samples with nondetectable concentrations were reassigned a value of half the laboratory reporting level for plotting purposes; the laboratory reporting level is indicated on the boxplot. Cadmium and silver are not included in the boxplot, because all sample values in the COA study (Mosier and others, 1991) were less than the laboratory reporting level of 2 milligrams per kilogram $(\mathrm{mg} / \mathrm{kg})$.

Results from the Wilcoxon rank sum test show that the trace element median concentrations in soil from this study were either similar to or less than median concentrations in soil from the COA study. Arsenic, lead, nickel, and zinc median concentrations in soils from this study were greater than concentrations in COA rock samples. Chromium, copper, and manganese median concentrations in soils from this study were similar to median concentrations in COA rock samples. Results from this statistical comparison of median concentrations suggest that the trace-element concentrations in soils from the study area are not elevated above background soil concentrations, although some are elevated above outcropping COA rock concentrations.

The soil sample laboratory results were compared to the U.S. Environmental Protection Agency, Region 6, Human Health Medium-Specific Screening Levels 2007 for Residential, Industrial Indoor, and Industrial Outdoor Soils (U.S. Environmental Protection Agency, 2006) (table 2). These screening levels address common human health exposure pathways, but do not consider all exposure pathways nor address ecological concerns. Soil samples SS1-C, SS6-C, and SS7-C exceeded the Residential Soil Screening Level for manganese of 3,200 $\mathrm{mg} / \mathrm{kg}$. All other sample values for manganese were less than the Industrial Indoor and Industrial Outdoor Soil Screening 


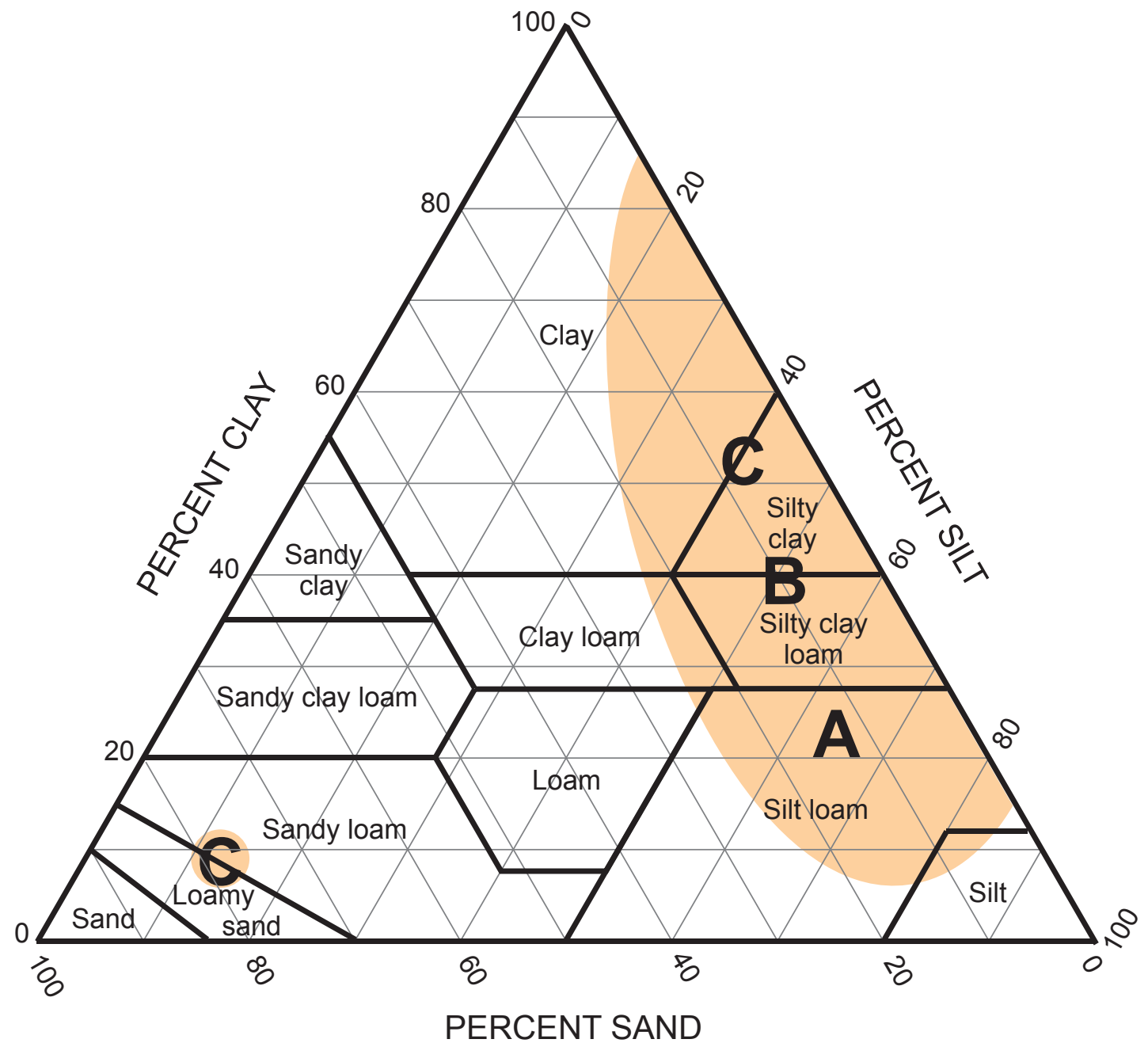

Figure 6. Approximate range in soil textures found in the $A, B$, and $C$ horizons of soil cores collected from abandoned oilfield-service site near Shawnee, Oklahoma, 2005-2006 (Modified from United States Department of Agriculture, 1993). 


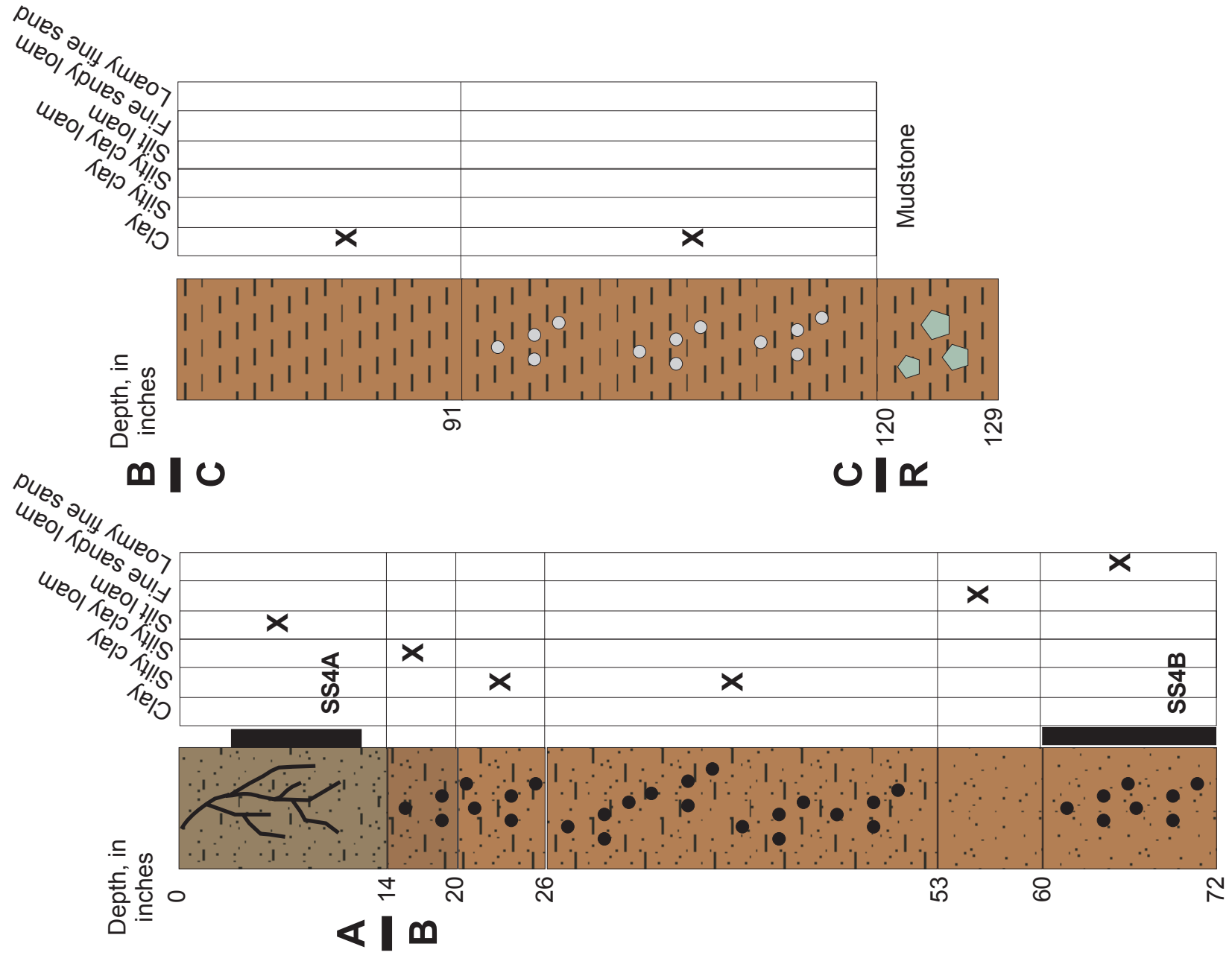




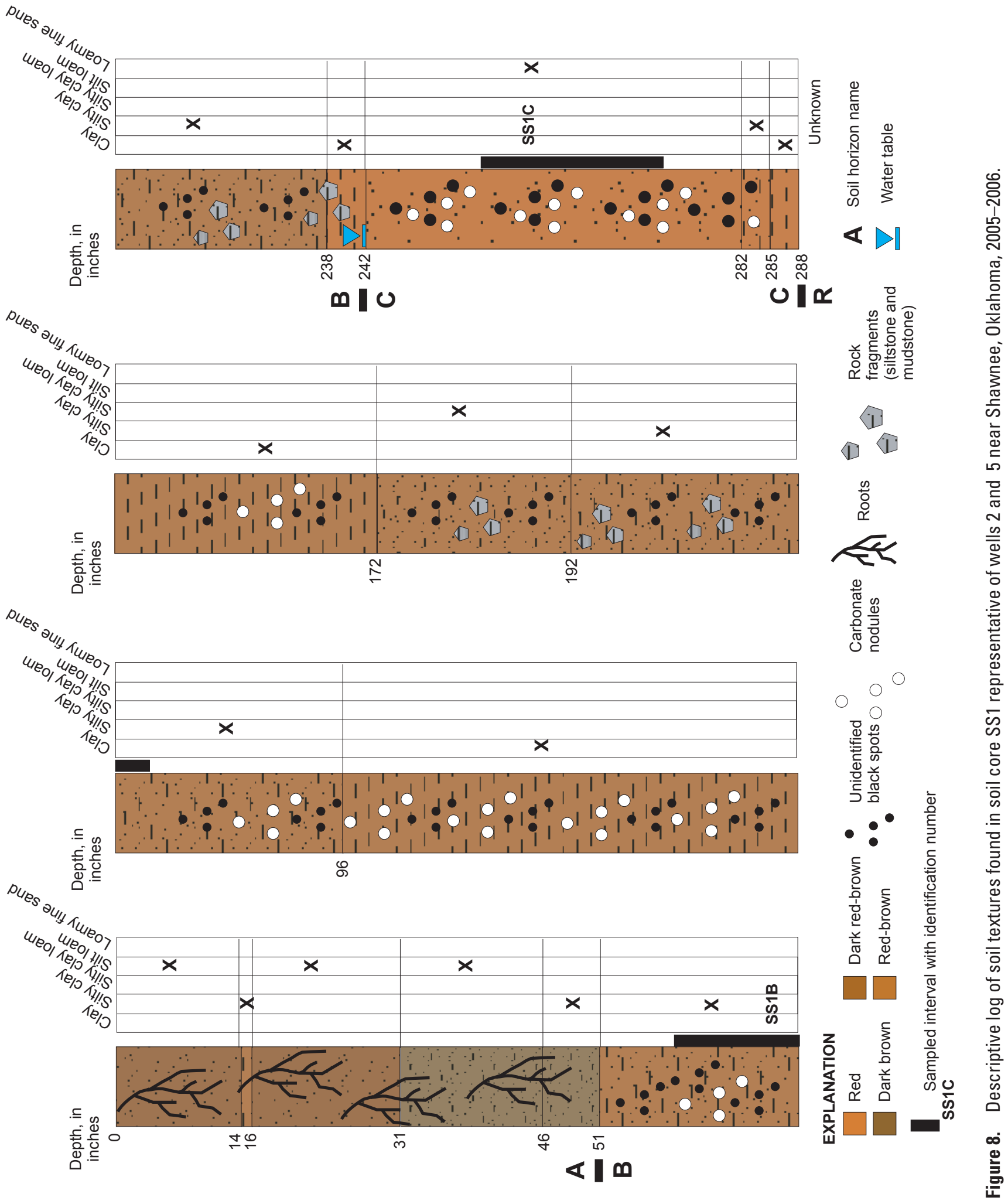



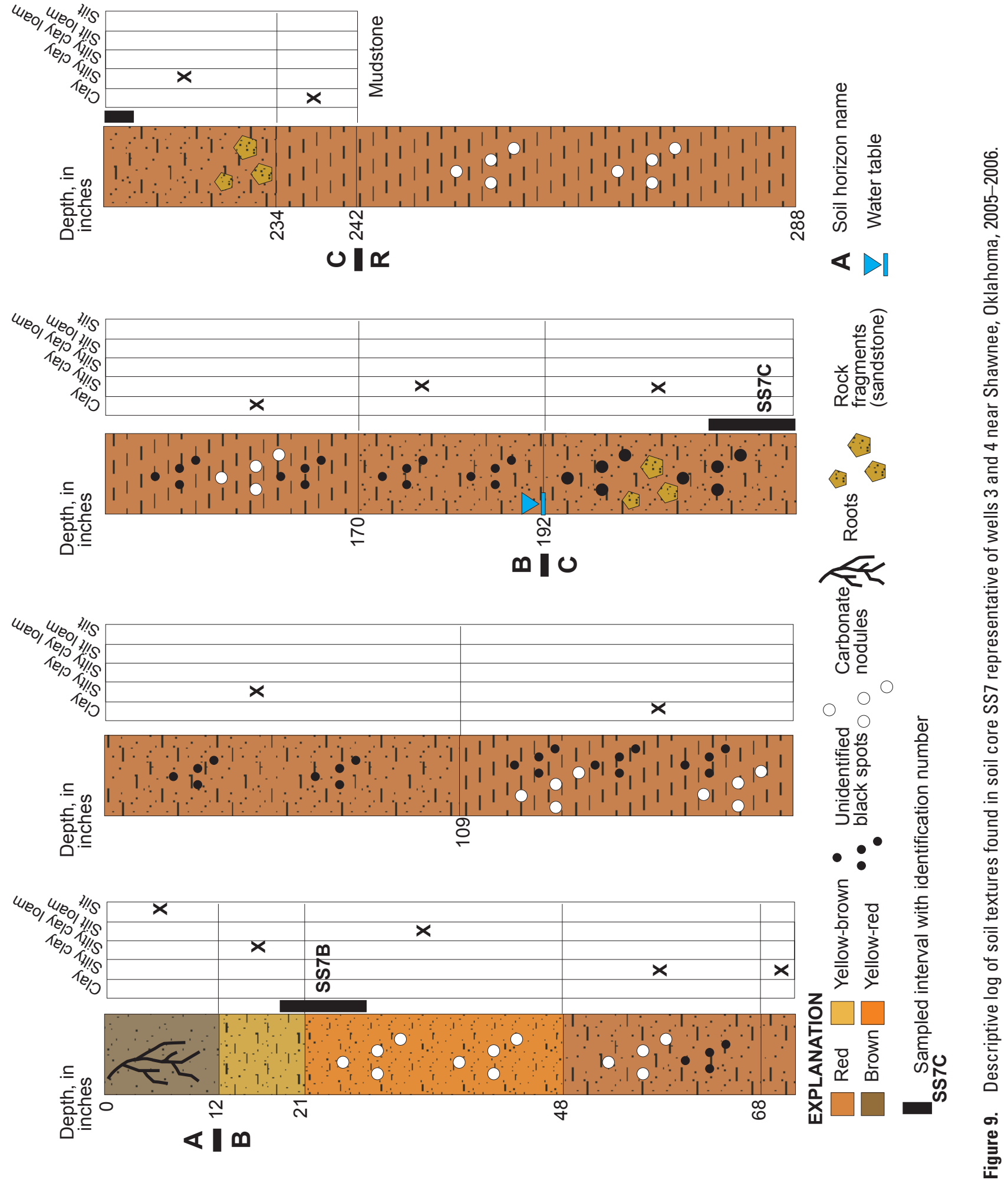


\section{EXPLANATION}

TOTAL TRACE-ELEMENT

CONCENTRATION IN MICROGRAMS PER KILOGRAM

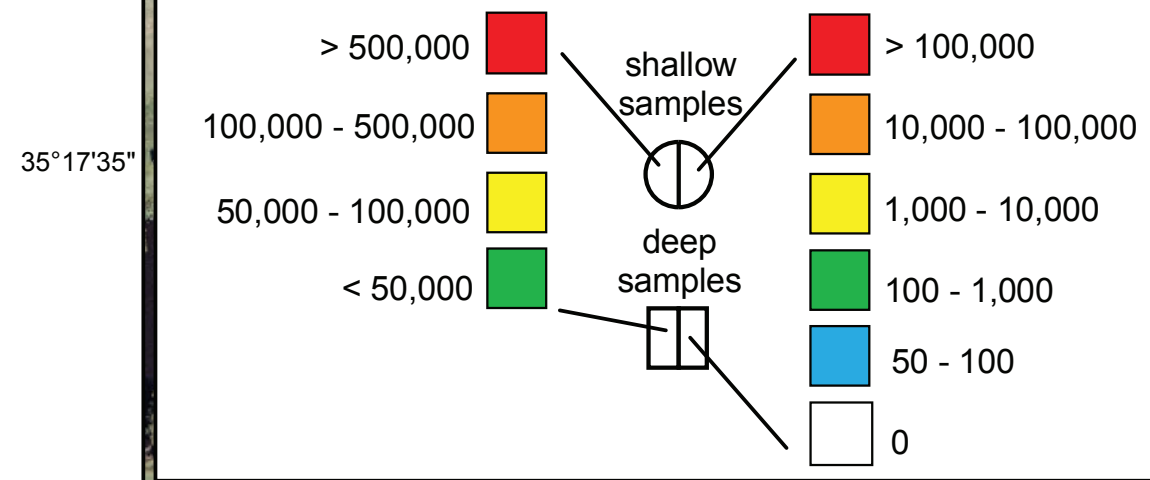

TOTAL SEMIVOLATILE ORGANIC COMPOUND CONCENTRATION IN MICROGRAMS PER KILOGRAM

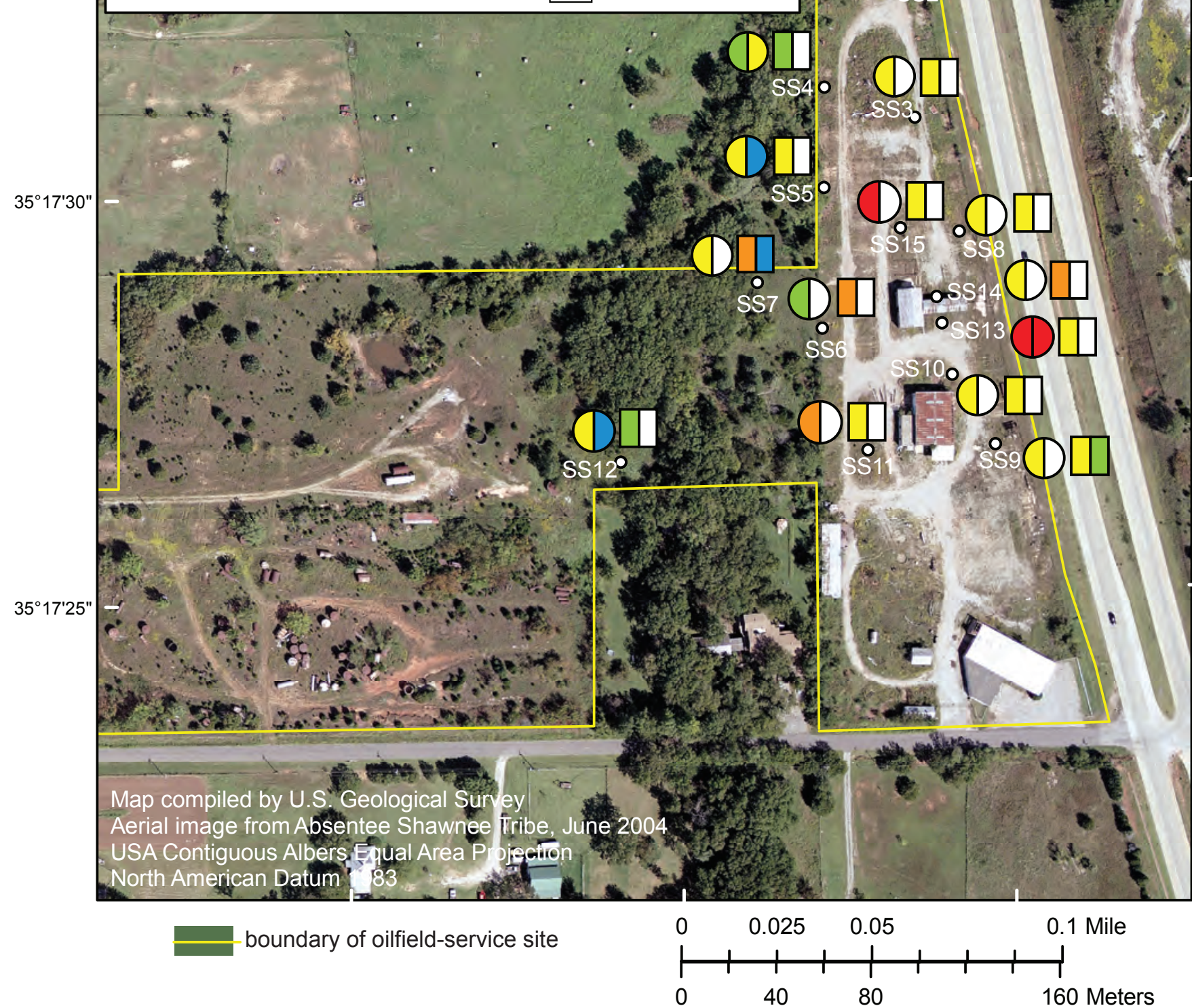

Figure 10. Total trace-element and semivolatile organic compound concentrations in soil samples near Shawnee, Oklahoma, 2005-2006. 


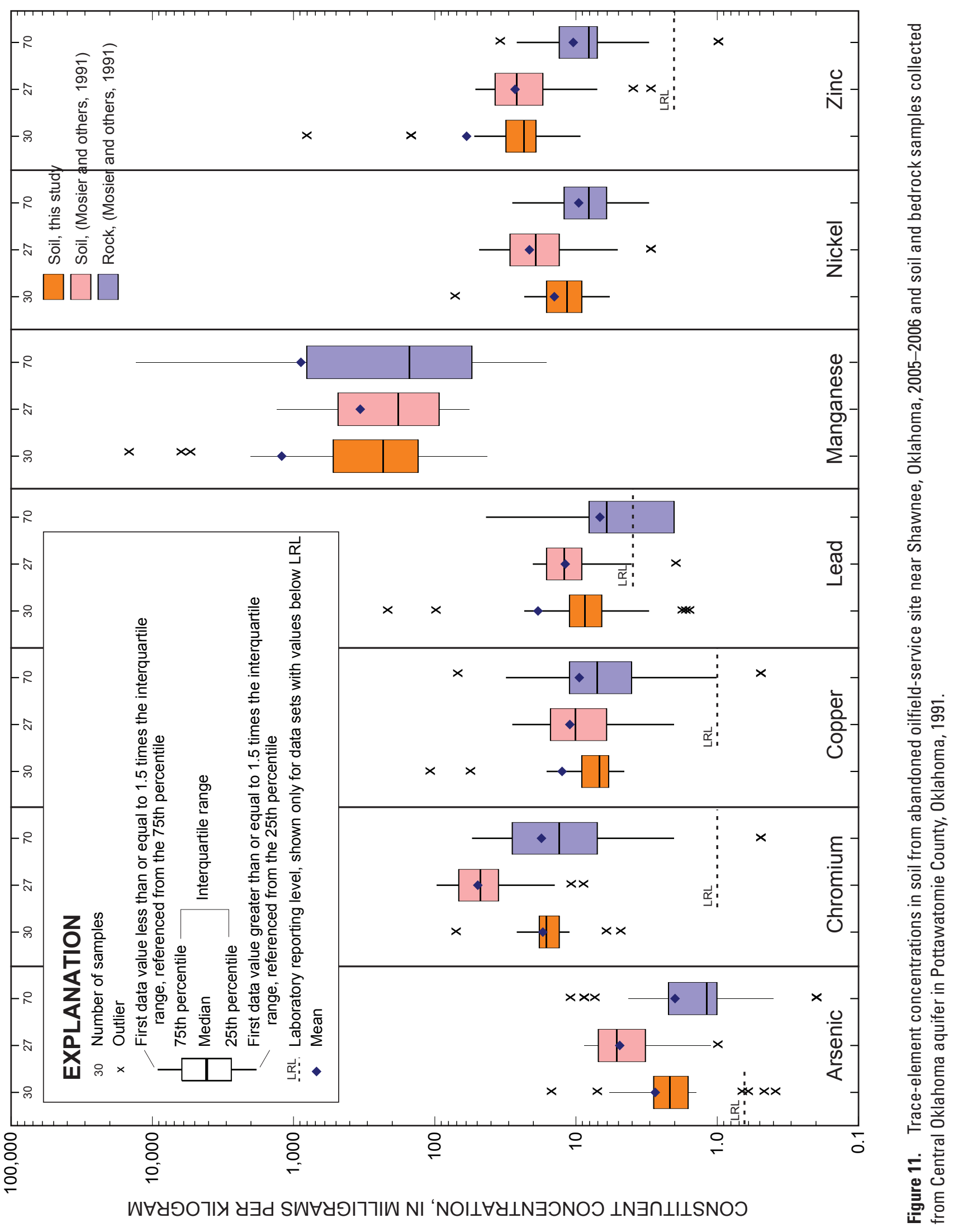




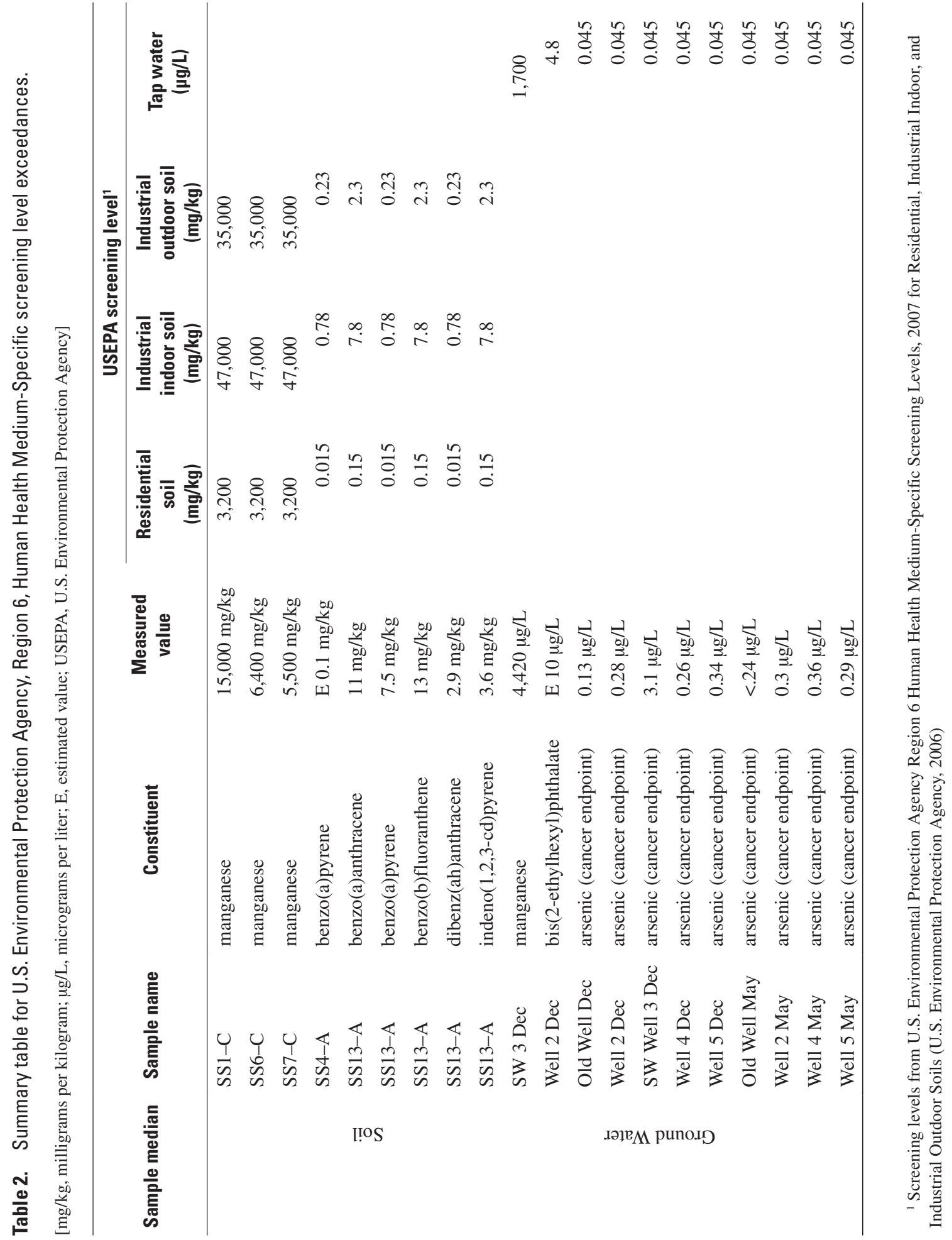


Table 3. Ground-water levels measured in wells near Shawnee, Oklahoma, 2005-2006.

[dd.dddddd, decimal degrees; , approximately; nw, no water in well]

\begin{tabular}{|c|c|c|c|c|c|}
\hline Local identifier & $\begin{array}{c}\text { Latitude } \\
\text { (dd.dddddd) }\end{array}$ & $\begin{array}{l}\text { Longitude } \\
\text { (-dd.dddddd) }\end{array}$ & Date & $\begin{array}{l}\text { Well depth } \\
\text { (feet below } \\
\text { land surface) }\end{array}$ & $\begin{array}{l}\text { Water level } \\
\text { (feet below } \\
\text { land surface) }\end{array}$ \\
\hline Old Well & 35.291 & -96.943 & $12 / 5 / 2005$ & $\sim 250$ & 36.6 \\
\hline Old Well & 35.291 & -96.943 & $1 / 20 / 2006$ & $\sim 250$ & 37.8 \\
\hline Well 1 & 35.293 & -96.944 & $1 / 20 / 2006$ & 15 & nw \\
\hline Well 2 & 35.293 & -96.943 & $1 / 20 / 2006$ & 24 & 11.8 \\
\hline SW 3 & 35.292 & -96.944 & $1 / 20 / 2006$ & 19 & 14.6 \\
\hline Well 4 & 35.291 & -96.944 & $1 / 20 / 2006$ & 22 & 12.8 \\
\hline Well 5 & 35.293 & -96.943 & $1 / 20 / 2006$ & 17 & 10.9 \\
\hline Old Well & 35.291 & -96.943 & $3 / 20 / 2006$ & $\sim 250$ & 36.9 \\
\hline Well 1 & 35.293 & -96.944 & $3 / 20 / 2006$ & 15 & nw \\
\hline Well 2 & 35.293 & -96.943 & $3 / 20 / 2006$ & 24 & 9.9 \\
\hline SW 3 & 35.292 & -96.944 & $3 / 20 / 2006$ & 19 & 14.0 \\
\hline Well 4 & 35.291 & -96.944 & $3 / 20 / 2006$ & 22 & 12.3 \\
\hline Well 5 & 35.293 & -96.943 & $3 / 20 / 2006$ & 17 & 8.7 \\
\hline Old Well & 35.291 & -96.943 & $3 / 21 / 2006$ & $\sim 250$ & 37.1 \\
\hline Well 1 & 35.293 & -96.944 & $3 / 21 / 2006$ & 15 & nw \\
\hline Well 2 & 35.293 & -96.943 & $3 / 21 / 2006$ & 24 & 9.9 \\
\hline SW 3 & 35.292 & -96.944 & $3 / 21 / 2006$ & 19 & 14.1 \\
\hline Well 4 & 35.291 & -96.944 & $3 / 21 / 2006$ & 22 & 12.4 \\
\hline Well 5 & 35.293 & -96.943 & $3 / 21 / 2006$ & 17 & 8.8 \\
\hline Old Well & 35.291 & -96.943 & $3 / 22 / 2006$ & $\sim 250$ & 36.8 \\
\hline Well 1 & 35.293 & -96.944 & $3 / 22 / 2006$ & 15 & nw \\
\hline Well 2 & 35.293 & -96.943 & $3 / 22 / 2006$ & 24 & 10.1 \\
\hline SW 3 & 35.292 & -96.944 & $3 / 22 / 2006$ & 19 & 14.1 \\
\hline Well 4 & 35.291 & -96.944 & $3 / 22 / 2006$ & 22 & 12.0 \\
\hline Well 5 & 35.293 & -96.943 & $3 / 22 / 2006$ & 17 & 10.3 \\
\hline Old Well & 35.291 & -96.943 & $3 / 23 / 2006$ & $\sim 250$ & 37.6 \\
\hline Well 1 & 35.293 & -96.944 & $3 / 23 / 2006$ & 15 & nw \\
\hline Well 2 & 35.293 & -96.943 & $3 / 23 / 2006$ & 24 & 10.0 \\
\hline SW 3 & 35.292 & -96.944 & $3 / 23 / 2006$ & 19 & 13.7 \\
\hline Well 4 & 35.291 & -96.944 & $3 / 23 / 2006$ & 22 & 12.4 \\
\hline Well 5 & 35.293 & -96.943 & $3 / 23 / 2006$ & 17 & 10.9 \\
\hline Old Well & 35.291 & -96.943 & $3 / 24 / 2006$ & $\sim 250$ & 36.9 \\
\hline Well 1 & 35.293 & -96.944 & $3 / 24 / 2006$ & 15 & nw \\
\hline
\end{tabular}


Table 3. Ground-water levels measured in wells near Shawnee, Oklahoma, 2005-2006.-Continued [dd.dddddd, decimal degrees; , approximately; nw, no water in well]

\begin{tabular}{lccccc}
\hline Local identifier & $\begin{array}{c}\text { Latitude } \\
\text { (ddd.ddddd) }\end{array}$ & $\begin{array}{c}\text { Longitude } \\
\text { (-dd.ddddd) }\end{array}$ & Date & $\begin{array}{c}\text { Well depth } \\
\text { (feet below } \\
\text { land surface) }\end{array}$ & $\begin{array}{c}\text { Water level } \\
\text { (feet below } \\
\text { land surface) }\end{array}$ \\
\hline Well 2 & 35.293 & -96.943 & $3 / 24 / 2006$ & 24 & 10.0 \\
SW 3 & 35.292 & -96.944 & $3 / 24 / 2006$ & 19 & 11.1 \\
Well 4 & 35.291 & -96.944 & $3 / 24 / 2006$ & 22 & 12.4 \\
Well 5 & 35.293 & -96.943 & $3 / 24 / 2006$ & 17 & 10.8 \\
& & & & & \\
Old Well & 35.291 & -96.943 & $5 / 1 / 2006$ & $\sim 250$ & 37.6 \\
Well 1 & 35.293 & -96.944 & $5 / 1 / 2006$ & 15 & 10.0 \\
Well 2 & 35.293 & -96.943 & $5 / 1 / 2006$ & 24 & 12.1 \\
SW 3 & 35.292 & -96.944 & $5 / 1 / 2006$ & 19 & 12.5 \\
Well 4 & 35.291 & -96.944 & $5 / 1 / 2006$ & 22 & 9.0 \\
Well 5 & 35.293 & -96.943 & $5 / 1 / 2006$ & 17 & 17 \\
\hline
\end{tabular}




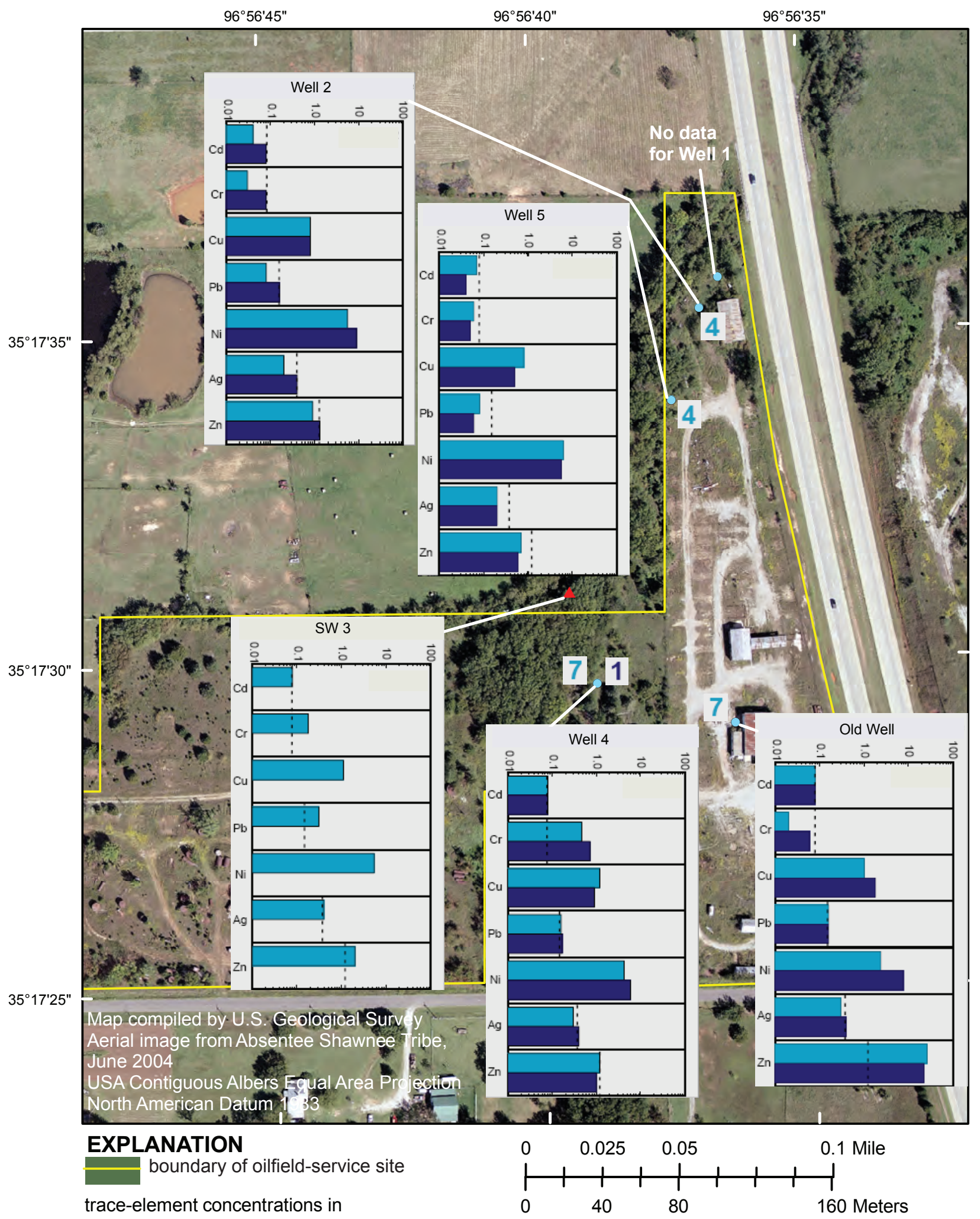

histograms are in micrograms per liter

\begin{tabular}{|l|ll}
\hline December 2005 samples & $\begin{array}{l}\text { highest laboratory reporting level } 7 \\
\text { (LRL), shown only for data sets } \\
\text { Mith values below highest LRL }\end{array}$ & $\begin{array}{l}\text { December } 2005 \text { number of SVOC } \\
\text { detections }\end{array}$ \\
May 2006 number of SVOC detections
\end{tabular}

Figure 12. Trace elements and semivolatile organic compounds (SVOC) in ground-water samples near Shawnee, Oklahoma, 2005-2006. 
Levels for manganese. Soil sample SS4-A exceeded the Residential Soil Screening Level for benzo(a)pyrene of $0.015 \mathrm{mg} / \mathrm{kg}$. Soil sample SS13-A exceeded the Residential Soil Screening Levels for benzo(a)anthracene $(0.15 \mathrm{mg} / \mathrm{kg})$, benzo(a)pyrene $(0.015 \mathrm{mg} / \mathrm{kg})$, benzo(b)fluoranthene $(0.15 \mathrm{mg} / \mathrm{kg})$, dibenz $(\mathrm{ah})$ anthracene $(0.015 \mathrm{mg} / \mathrm{kg})$, and indeno(1,2,3-cd)pyrene $(0.15 \mathrm{mg} / \mathrm{kg})$. Soil sample SS13-A exceeded the Industrial Indoor Soil Screening Levels for benzo(a)anthracene $(7.8 \mathrm{mg} / \mathrm{kg})$, benzo(a)pyrene $(0.78 \mathrm{mg} / \mathrm{kg})$, benzo(b)fluoranthene $(7.8 \mathrm{mg} / \mathrm{kg})$, and dibenz(ah)anthracene $(0.78 \mathrm{mg} / \mathrm{kg})$. Soil sample SS13-A exceeded the Industrial Outdoor Soil Screening Levels for benzo(a)anthracene $(2.3 \mathrm{mg} / \mathrm{kg}$ ), benzo(a)pyrene $(0.23 \mathrm{mg} / \mathrm{kg})$, benzo(b)fluoranthene $(2.3 \mathrm{mg} / \mathrm{kg})$, dibenz $(\mathrm{ah})$ anthracene $(0.23 \mathrm{mg} / \mathrm{kg})$, and indeno(1,2,3-cd)pyrene $(2.3 \mathrm{mg} / \mathrm{kg})$.

\section{Ground-Water Chemical Analysis}

Ground-water levels were measured in the wells during December 2005, and January, March, and May 2006. The January median water level was 12.3 feet. The May median water level was 11 feet (table 3). The water levels increased in all the wells from January to May ranging from 0.3 foot to 2.5 feet. The ground-water level also was measured in the Old Well in December 2005 at the time the well was sampled. Daily ground-water levels were measured for 5 days following a 1.73-inch rainfall event on March 18 and 19 (Oklahoma Climatological Survey, 2006) to determine how quickly the wells responded to precipitation. The March data indicated that the water levels peaked 2 to 3 days after the rain event. The May sampling was completed 2 to 3 days after 2.36 inches of rain fell on April 28 and 29 (Oklahoma Climatological Survey, 2006). Wells 1 and 3 did not produce enough water to sample during either sampling event. Because Well 3 was located in close proximity to the creek, a surface-water sample was collected in December 2005 for laboratory analysis and labeled SW 3.

Old Well, Well 2, SW 3, and Well 5 December groundwater samples had the most trace-element detections (fig. 12 and appendix 3). Most of these concentrations were near the laboratory reporting level. The Old Well contained a zinc concentration of 26 micrograms per liter $(\mu \mathrm{g} / \mathrm{L})$. The casing for the Old Well was made of steel and water in the well was not purged prior to sampling, and some of these trace elements could have leached from the casing into the well water. Water samples from the Old Well, Well 2, Well 4, and Well 5 also had the most trace-element detections in the May sampling. Most of these concentrations were near the laboratory reporting level, except the Old Well, which had a zinc concentration of $21.8 \mu \mathrm{g} / \mathrm{L}$.

December ground-water samples for the Old Well contained seven SVOC detections and Well 2 contained four SVOC detections. Most of these concentrations were near the laboratory reporting level, although SW 3 contained an estimated value of $37.8 \mu \mathrm{g} / \mathrm{L}$ for phenol. There were no other detections for phenol in either ground-water or soils that would indicate phenol was from the study area and most likely was from upstream. The presence of some constituents was verified, but not quantified. Only one compound (anthracene) was detected in May and that was in Well 4. The anthracene presence was verified, but not quantified. The increase in water levels in the wells during May might have caused some dilution of SVOCs in the May ground-water samples; although there was no obvious difference in ground-water trace-element detections between December and May.

Dissolved trace-element concentrations from shallow (less than 100 feet) bedrock aquifer wells in Pottawatomie County were obtained from the USGS National Water Information System (NWIS) database. Eighty-three samples were retrieved from the NWIS database that were collected between 1977 and 2006. The difference in laboratory reporting levels for the NWIS data and data from this study did not permit a comparison.

The ground-water data were compared to the U.S. Environmental Protection Agency Region 6 Human Health Medium-Specific Screening Levels 2007 for Tap Water (U.S. Environmental Protection Agency, 2006) (table 2). The December sample from SW 3 exceeded the tap water screening level for manganese of $1,700 \mu \mathrm{g} / \mathrm{L}$. All wells for both December and May exceeded the tap water screening level for arsenic of

$0.045 \mu \mathrm{g} / \mathrm{L}$. The December sample from Well 2 exceeded the tap water screening level for bis(2-ethylhexyl) phthalate of $4.8 \mu \mathrm{g} / \mathrm{L}$.

Manganese and arsenic are naturally occurring elements in the local bedrock and soils. Mosier and others (1990) report the median concentration of manganese in subsurface rock of Permian age was 425 parts per million (ppm), or milligrams per kilogram and arsenic was $10 \mathrm{ppm}$. Outcrop samples from the Chase, Council Grove, and Admire Groups contained a median concentration for manganese of $200 \mathrm{ppm}$ and for arsenic of $1.2 \mathrm{ppm}$ (Mosier and others, 1991). B-horizon soil samples from Mosier and others (1991) contained a median concentration for manganese at $280 \mathrm{ppm}$ and for arsenic of $5.1 \mathrm{ppm}$.

\section{Plant Chemical Analysis and Relation to Trace elements in Soils and Ground Water}

Trace-element concentrations for seven trace elements (cadmium, chromium, copper, lead, nickel, silver, and zinc) were totaled to determine total trace element concentration per sample (raw data in appendix 4). Plant sample 7J contained a total trace element concentration of $190 \mathrm{ppm}$ for the seven trace elements (fig. 13). Plant sample 25J contained a total 


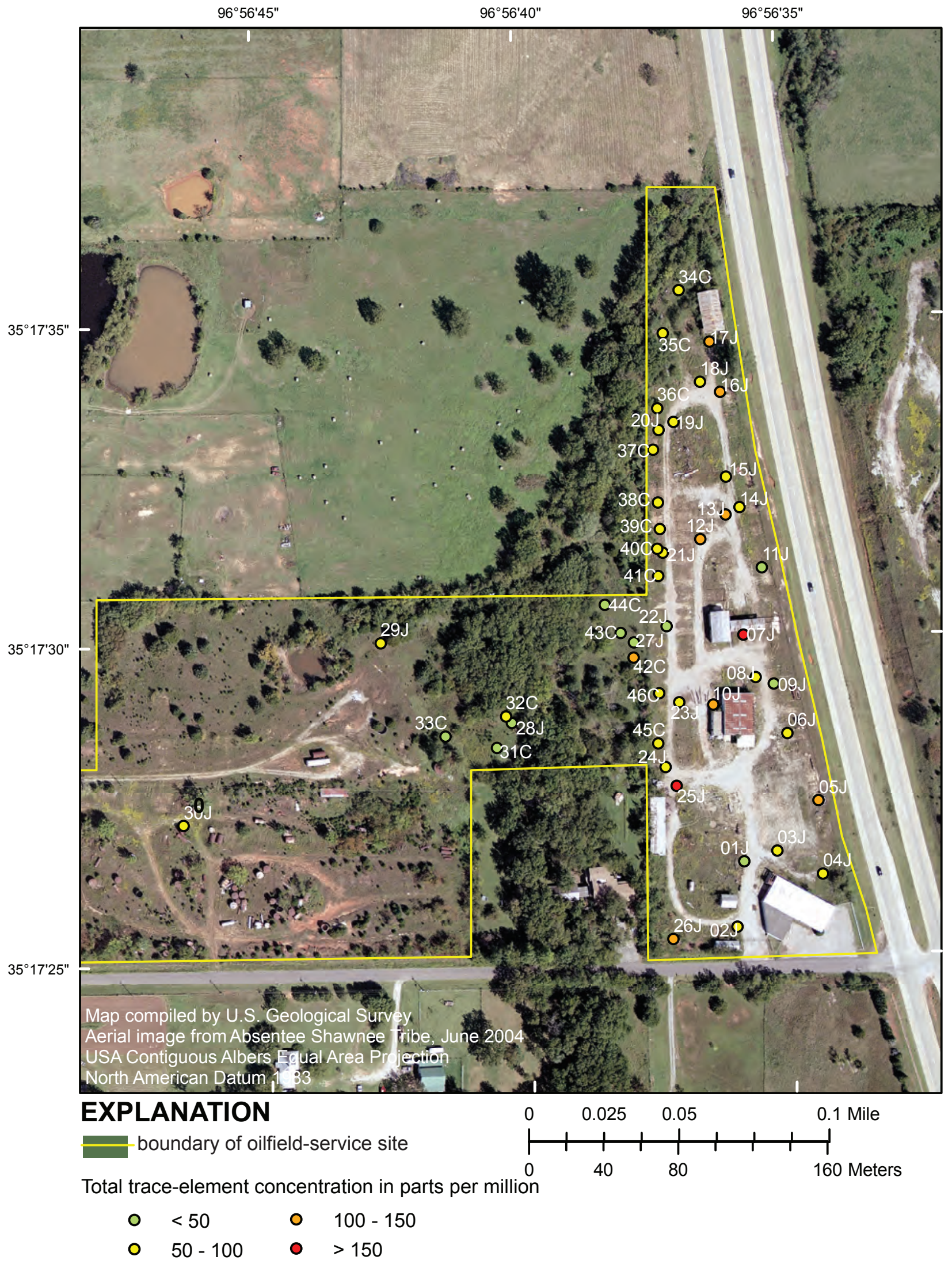

Figure 13. Total trace-element concentrations in plant samples near Shawnee, Oklahoma, 2005-2006. 
trace element concentration of $181 \mathrm{ppm}$ for the seven trace elements. Sample 7J was located near the threading barn and 25J was located west of the vehicle maintenance garage. Summary statistics for trace-element concentrations in plant samples are presented in boxplots on figure 14 .

Using plant tissue analyses as a surrogate for soil and ground-water contamination is a relatively new analytical application. Few data are reported in literature for comparing concentrations in this study to other studies. The previous studies that have been published do not sample Johnsongrass or Coralberry. Constituent concentrations in Johnsongrass and Coralberry were apparently taken up differently in each species (fig. 14). Any comparison of the analyses from this study area to similar constituents in other studies would have limited application. There also are no screening levels established for constituents in plant samples for comparison.

Correlation coefficients using the Spearman rank sum test were calculated for seven trace-element concentrations (cadmium, chromium, copper, lead, nickel, silver, and zinc) between (1) plants and shallow soils and (2) plants and deep soils for 10 locations where a soil sample was collected near a plant sample. Results of the Spearman rank test indicate that there was no correlation between the plant and soil sample concentrations based on the current sample size and study design. However, large zinc concentrations in soil (SS13) and in plant material $(7 \mathrm{~J})$ were measured near the threading barn. Zinc concentration in the A horizon at SS13 $(150,000 \mu \mathrm{g} / \mathrm{kg})$ was one of the largest in soil samples (appendix 2), and zinc concentration in a Johnsongrass sample at $7 \mathrm{~J}$ (184.5 ppm) was greater than in all other plant samples (appendix 4).

The lack of correlation between trace-element concentrations in plants and soils, and plants and ground water indicate that plant sampling was not useful as a preliminary tool to assess contamination at the study site. The lack of correlation could be due to several variables. The sampled plant species may not uptake the contaminated constituents as readily as other constituents or other species.

\section{Areas of Contamination}

Results of the soil, ground-water, and plant data suggest that the areas of trace-element and SVOC contamination are located in the shallow (A-horizon) soils near the threading barn. These contaminants could potentially leach to the deeper unconsolidated material and shallow ground water over time, and may eventually reach the intermittent creek that cuts across the study area. Contaminants in the shallow soils will not likely transport to the deeper bedrock aquifer (COA) because of the tight mudstone present at the base of the unconsolidated material. SVOC contaminants in the Old Well may have been caused from previous use of the well or from surface contamination. The Old Well could act as a conduit for transmitting contaminants from the surface to the bedrock aquifer. The presence of phenol in the stream was most likely from a source upstream from the study area because there was no phenol present in the other ground-water and soil samples at the time of sampling. The elevated manganese and arsenic concentrations were attributed to the ambient conditions in the local soil and bedrock. There was no apparent difference in trace-element and SVOC concentrations in ground-water samples from December to May.

\section{Summary}

The state of Oklahoma has a well-known history of oil and gas production beginning in the late 1800s (Oklahoma Energy Resources Board, 2006). Oilfield-service sites were an integral part of the oil and gas industry and used for storage and maintenance of oilfield equipment. The Absentee Shawnee Tribe of Oklahoma was working to reclaim an oilfieldservice site near Shawnee, Oklahoma and needed to determine the nature and extent of contamination to aid clean-up efforts. The oilfield service-site contained production storage tanks, production pipe, and warehouses and other buildings that were used to clean and cut production pipe. Wastes left behind on the oilfield-service site in Shawnee, Oklahoma consisted of pipes, cuttings from pipe threading, hydraulic fluid, oils, and solvents. The U.S. Geological Survey (USGS), in cooperation with the Absentee Shawnee Tribe of Oklahoma, began a reconnaissance study of a site in Pottawatomie County in 2005 by testing soil, shallow ground water, and plant material for the presence of trace elements and semivolatile organic compounds (SVOCs). Chemical analysis of plant material at the site was investigated as a preliminary tool to determine the extent of contamination at the site.

Thirty soil samples were collected from 15 soil cores during October 2005 and analyzed for trace elements and semivolatile organic compounds. Five small-diameter, polyvinylchloride-cased wells were installed to collect ground-water samples. Water samples were collected from the wells during December 2005 and May 2006 for analysis of trace elements and semivolatile organic compounds. Thirty Johnsongrass samples and 16 Coralberry samples were collected during September 2005 and analyzed for 53 constituents, including trace elements.

Soil samples SS15-A and SS13-A contained the highest total trace-element concentrations from the study area for cadmium, chromium, copper, lead, nickel, silver, and zinc. Soil samples SS13-A and SS4-A contained the highest total SVOC concentrations from the study area.

Results from the Wilcoxon rank sum test indicate that the trace-element concentrations in soils from the study area are not elevated above background soil concentrations, although some are elevated above outcropping Central Oklahoma aquifer rock concentrations.

Soil samples SS1-C, SS6-C, and SS7-C exceeded the Residential Soil Screening Level for manganese of $3,200 \mathrm{mg} / \mathrm{kg}$. All other sample values for manganese were less 
than the Industrial Indoor and Industrial Outdoor Soil Screening Levels for manganese. Soil sample SS4-A exceeded the Residential Soil Screening Level for benzo(a)pyrene of $0.015 \mathrm{mg} / \mathrm{kg}$. Soil sample SS13-A exceeded the Residential Soil Screening Levels for benzo(a)anthracene $(0.15 \mathrm{mg} / \mathrm{kg})$, benzo(a)pyrene $(0.015 \mathrm{mg} / \mathrm{kg})$, benzo(b)fluoranthene $(0.15$ $\mathrm{mg} / \mathrm{kg})$, dibenz(ah)anthracene $(0.015 \mathrm{mg} / \mathrm{kg})$, and indeno(1,2,3-cd)pyrene $(0.15 \mathrm{mg} / \mathrm{kg})$. Soil sample SS13-A exceeded the Industrial Indoor Soil Screening Levels for benzo(a)anthracene $(7.8 \mathrm{mg} / \mathrm{kg})$, benzo(a)pyrene $(0.78$ $\mathrm{mg} / \mathrm{kg})$, benzo(b)fluoranthene $(7.8 \mathrm{mg} / \mathrm{kg})$, and dibenz(ah) anthracene $(0.78 \mathrm{mg} / \mathrm{kg})$. Soil sample SS13-A exceeded the Industrial Outdoor Soil Screening Levels for benzo(a)anthracene $(2.3 \mathrm{mg} / \mathrm{kg})$, benzo(a)pyrene $(0.23 \mathrm{mg} / \mathrm{kg})$, benzo(b) fluoranthene $(2.3 \mathrm{mg} / \mathrm{kg})$, dibenz(ah)anthracene $(0.23 \mathrm{mg} / \mathrm{kg})$, and indeno(1,2,3-cd)pyrene $(2.3 \mathrm{mg} / \mathrm{kg})$.

Most of the trace-element and SVOC concentrations from the ground-water samples collected in December and May were near the laboratory reporting level. Although, the Old Well contained higher zinc concentrations in both the December and May samples. The casing for the Old Well was made of steel and water in the well was not purged prior to sampling, and some of these trace elements could have leached from the casing into the well water. SW 3 contained an estimated value of $37.8 \mu \mathrm{g} / \mathrm{L}$ for phenol.

The December sample from SW 3 exceeded the tap water screening level for manganese of 1,700 $\mu \mathrm{g} / \mathrm{L}$. All wells for both December and May exceeded the tap water screening level for arsenic of $0.045 \mu \mathrm{g} / \mathrm{L}$. The December sample from Well 2 exceeded the tap water screening level for bis(2-ethylhexyl) phthalate of $4.8 \mu \mathrm{g} / \mathrm{L}$.

Plant samples $7 \mathrm{~J}$ and $25 \mathrm{~J}$ contained the highest total trace-element concentrations for cadmium, chromium, copper, lead, nickel, silver, and zinc. Results of the Spearman rank test indicate that there was no correlation between the plant and soil concentrations based on the current sample size and study design. Large zinc concentrations in soil and in plant material were measured near the threading barn. The lack of correlation between trace-element concentrations in plants and soils, and plants and ground water indicate that plant sampling was not useful as a preliminary tool to assess contamination at the study site.

Results of the soil, ground-water, and plant data indicate that the areas of trace-element and SVOC contamination are located in the shallow (A-horizon) soils near the threading barn. These contaminants could potentially leach to the deeper unconsolidated material and shallow ground water over time, and may eventually reach the intermittent creek that cuts across the study area. Contaminants in the shallow soils will not likely transport to the deeper bedrock aquifer (COA) because of the tight mudstone present at the base of the unconsolidated material. SVOC contaminants in the Old Well may have been caused from previous use of the well or from surface contamination. The Old Well could act as a conduit for transmitting contaminants from the surface to the bedrock aquifer. The presence of phenol in the stream was most likely from a source upstream from the study area because there was no phenol present in the other ground-water and soil samples at the time of sampling. The elevated manganese and arsenic concentrations were attributed to the ambient conditions in the local soil and bedrock. There was no obvious difference in ground-water trace-element detections between December and May.

\section{Selected References}

Bingham, R.H., and Moore, R.L., 1975, Reconnaissance of the water resources of the Oklahoma City quadrangle, Central Oklahoma: Oklahoma Geological Survey Hydrologic Atlas HA-4, 4 sheets, scale 1:250,000.

Childress, C.J.O., Foreman, W.T., Connor, B.F., and Maloney, T.J., 1999, New reporting procedures based on longterm method detection levels and some considerations for interpretations of water-quality data provided by the U.S. Geological Survey National Water Quality Laboratory: U.S. Geological Survey Open-File Report 99-193, 19 p.

Christenson, S.C., Morton, R.B., and Messander, B.A., 1992, Hydrogeologic maps of the Central Oklahoma aquifer, Oklahoma: U.S. Geological Survey Hydrologic Investigations Atlas HA-724, 3 sheets, scale 1:250,000.

Erdman, J.A., and Christenson, Scott, 2000, Elements in Cottonwood Trees as an Indicator of Ground Water Contaminated by Landfill Leachate: Ground Water Monitoring \& Remediation, v. 20, no. 1, p.120-126.

Erdman, J.A., Vradenburg, L.A., and Smith, C.S., 2003, Willow-Leaf Analysis Determines Extent of Mine Contamination Plume on the Willow Creek Floodplain, Creede, Colorado: accessed January 26, 2005, at http://www. willowcreede.org/waterquality/Willow\%20Final.pdf

Helsel, D.R., 2005, Nondetects and data analysis: Statistics for censored environmental data: John Wiley \& Sons, Inc., $250 \mathrm{p}$.

Helsel, D.R., and Hirsch, R.M., 2002, Statistical methods in water resources: U.S. Geological Survey Techniques of Water-Resources Investigations, Book 4, Chapter A3.

Howarth, R.J., and Govett, G.J.S., 1983, Handbook of Exploration Geochemistry: Elsevier Scientific Publishing Company, v. 2, p. 64.

Meinzer, O.E., 1923, Outline of ground-water hydrology with definitions: U.S. Geological Survey Water-Supply Paper 494, 71 p.

Meinzer, O.E., 1927, Plants as indicators of ground water: U.S. Geological Survey Water-Supply Paper 577, 95 p. 
Mosier, E.L., Briggs, P.H., Crock, J.G., Kennedy, K.R., McKown, D.M., Vaughn, R.B., and Welsch, E.P., 1990, Analyses of subsurface Permian rock samples from the Central Oklahoma aquifer: U.S. Geological Survey Open-File Report 90-456, 58 p.

Mosier, E.L., Bullock, J.H., Jr., Fey, D.L., Kennedy, K.R., McKown, D.M., Vaughn, R.B., and Welsch, E.P., 1991, Elemental composition of surficial materials from Central Oklahoma: U.S. Geological Survey Open-File Report 91-442A, 62 p.

Oklahoma Climatological Survey, 2002, Oklahoma Annual Climate Summary, 2004 Board of Regents of the University of Oklahoma: accessed March 20, 2006, at http://climate. ocs.ou.edu/annual_summary.htm

Oklahoma Climatological Survey, 2006, Mesonet Climatological Data Summary for Shawnee Station, Board of Regents of the University of Oklahoma: accessed January 16, 2007, at http://www.mesonet.ou.edu/public/summary.html

Oklahoma Energy Resources Board, 2006, Approximately 750,000 oil wells have been drilled in Oklahoma: accessed March 20, 2006, at http://www.oerb.com/industry/history_3. asp

Parkhurst, D.L, Christenson, S.C., and Breit, G.N., 1996, Ground-water quality assessment of the central Oklahoma Aquifer, Oklahoma; geochemical and geohydrologic investigations: U.S. Geological Survey Water Supply Paper 2357-C, 101 p.

Rose, A.W., Hawkes, H.E., and Webb, J.S., 1979, Geochemistry in Mineral Exploration (2d ed.): San Diego, California, Academic Press Inc., chap. 17, 657 p.
Soil Conservation Service, 1977, Soil Survey of Pottawatomie County, Oklahoma, 118 p.

Smith, David B., Cannon, William F., Woodruff, Laurel G., Garrett, Robert G., Klassen, Rodney, Kilburn, James E., Horton, John D., King, Harley D., Goldhaber, Martin B., Morrison, Jean M., 2005, Major- and trace-element concentrations in soils from two continental-scale transects of the United States and Canada: U.S. Geological Survey OpenFile Report 2005-1253, 22 p.

Tortorelli, R.L., 2004, Estimated freshwater withdrawals in Oklahoma, 2000: U.S. Geological Survey: accessed January 11, 2007, at http://ok.water.usgs.gov/wateruse/wateruse00. html

U.S. Department of Agriculture, 1993, Soil Survey Manual, Handbook No. 18, p. 138.

U.S. Department of Agriculture, 2007, Natural Resources Conservation Service Plants Database: accessed January 11, 2007, at http://plants.usda.gov/index.html

U.S. Environmental Protection Agency, 1983, Methods for chemical analysis of water and wastes: Cincinnati, Ohio, EPA-600/4-79-020, variable pagination.

U.S. Environmental Protection Agency, 1986 (revised December 1996), Test methods for evaluating solid waste, physical/chemical methods: Washington, D.C., U.S. Government Printing Office, EPA-SW-846, variable pagination.

U.S. Environmental Protection Agency, 2006 (revised December, 22, 2006), Region 6 Human Health Medium-Specific Screening Levels 2007: accessed April 12, 2007, at http://www.epa.gov/Arkansas/6pd/rcra_c/pd-n/screen.htm

Prepared by Lawrence Publishing Service Center.

Edited by Lyn Osburn

Layout and design by Lyn Osburn.

For more information concerning the research

described in this report, contact:

U.S. Geological Survey

202 NW 66th St., Bldg. 7

Oklahoma City, OK 73116

(405) 810-4400

http://ok.water.usgs.gov 


\section{Appendixes}




\section{Appendix 1. Quality control data}

Quality-control samples were collected and analyzed to evaluate the degree of accuracy, precision, and bias of environmental samples. Quality control for the plant samples consisted of six replicate environmental samples. Quality control for the soil samples consisted of three replicate environmental samples. Quality control for the ground-water samples consisted of one equipment blank, one field blank, and two replicate environmental samples.

Precision was calculated as the relative percent difference (RPD) between the initial environmental sample and the replicate environmental sample by equation 1 :

where

$$
\mathrm{RPD}=|\mathrm{C} 1-\mathrm{C} 2| /((\mathrm{C} 1+\mathrm{C} 2) / 2) * 100
$$

$\mathrm{C} 1$ = initial environmental sample value;

$\mathrm{C} 2$ = replicate environmental sample value

Bias, where evident, was calculated as the percent difference (PD) between the initial environmental sample and the replicate environmental sample by equation 2 :

$$
\mathrm{PD}=[(\mathrm{C} 1-\mathrm{C} 2) / \mathrm{C} 1)] * 100
$$

where

$\mathrm{C} 1$ = initial environmental sample value;

$\mathrm{C} 2$ = replicate environmental sample value

Three replicate soil samples were collected by filling a second jar from the same core zone as the initial soil sample (table 4). The RPD values for the soil samples were variable. There appeared to be some bias in the replicate sample results. The trace-element results for replicate SS6-CR showed that 75 percent of detections were at least 20 percent greater in the replicate sample. The semivolatile organic compound results for replicate SS6-CR showed that all detections were at least 20 percent greater in the replicate sample. This low bias may be caused by variations between the environmental sampling method and the replicate sampling method, or variations in the soil itself. The trace-element results for replicate SS12-B1R showed most detections were greater in the replicate and 30 percent of detections were within 20 percent of the environmental sample. The semivolatile organic compound results for replicate SS12-B1R showed that all detections were at least 20 percent different. The trace-element results for replicate SS14-BR showed that about 30 percent of detections were greater than 20 percent different. The semivolatile organic compound results for replicate SS14-BR showed that 50 percent of detections matched concentrations in the environmental sample and the remaining 50 percent were within 20 percent of the environmental sample, which suggests that the replicate was in good agreement with the environmental sample.

Two replicate ground-water samples were collected in the exact same manner that the initial environmental sample was collected (table 5). The RPD values for the ground-water samples were less than or equal to 5 percent for most trace elements detected at concentrations greater than the reporting level. Only copper (14 percent) and zinc ( 9 percent) concentrations had relative percent differences greater than 5 percent. Replicate ground-water samples suggest that the sampling and analysis of trace elements and semivolatile organic compounds in this investigation were repeatable and free from large sources of error.

Six replicate plant samples were collected by filling a second cloth sample bag with plant material from the same plant sample location as the initial plant sample (table 6). Roughly 40 to 50 percent of detected trace elements had RPDs greater than 20 percent. The poor agreement of replicate samples with environmental samples was probably due to a number of factors including the natural variability in concentrations in plant tissues and the difficulty of collecting true replicate plant samples, and may be because most trace-element detections were near the laboratory reporting level.

The equipment blank was used to determine if the environmental ground-water samples were contaminated by the well screen and sampling equipment. The equipment blank was prepared in the laboratory prior to collecting environmental samples, by processing quality-assured high purity organic blank water through a prepacked well screen and sampling equipment in the same manner that the environmental samples were collected. Aluminum was found in high concentrations $(35.9 \mu \mathrm{g} / \mathrm{L})$ in the equipment blank. Zinc $(0.774 \mu \mathrm{g} / \mathrm{L})$ and copper $(0.855 \mu \mathrm{g} / \mathrm{L})$ were detected in concentrations comparable to those found in environmental samples. Molybdenum, manganese, nickel, and barium also were detected in the equipment blank, but in concentrations less than the minimum concentration detected in environmental samples. The equipment blank also had semivolatile organic compound detections near the laboratory reporting level, specifically di-n-butyl phthalate, isophorone, phenol, and naphthalene.

The field blank was used to determine if environmental ground-water samples were contaminated during the sampling process in the field. The field blank was prepared in the field by processing quality-assured high purity organic blank water through the sampling equipment in the same manner that the environmental samples were collected. Aluminum was found in high concentrations $(54.8 \mu \mathrm{g} / \mathrm{L})$ in the field blank. Aluminum concentrations of most environmental water samples were less than the reporting level. Chromium was detected in concentrations $(0.2 \mu \mathrm{g} / \mathrm{L})$ comparable to those found in environmental samples. Chromium, nickel, manganese, and barium also were detected in the field blank, but in concentrations less than the minimum concentration detected in environmental samples.

The aluminum concentration in the field blank was greater than the aluminum concentration in the equipment blank, which indicate that the aluminum likely was leaching from the sand prepacked well screen during well development. According to analysis of blank and replicate water samples, prepack materials do not appear to be substantial sources of other trace elements and semivolatile organic compounds detected in sampled ground-water in this investigation. 


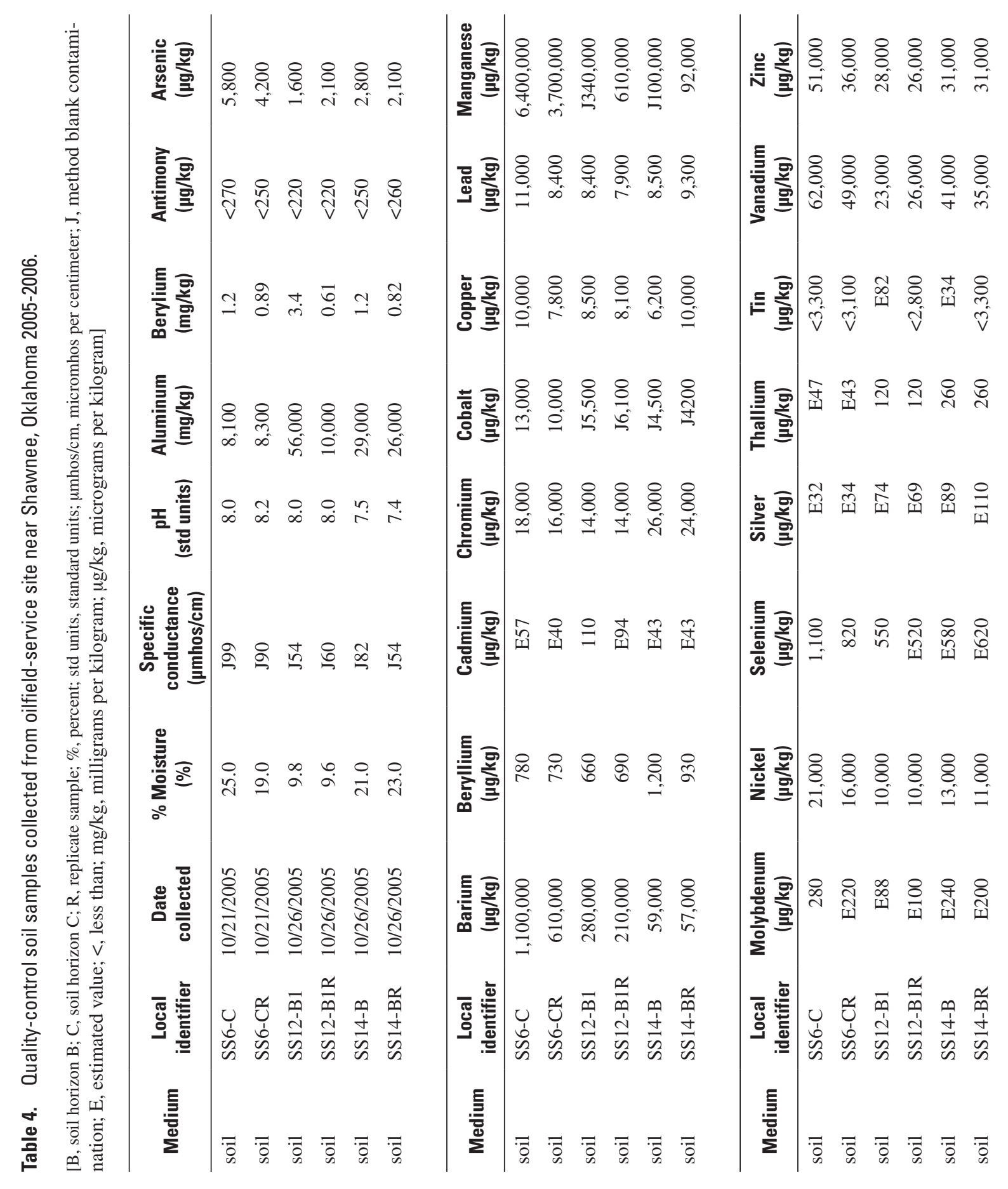



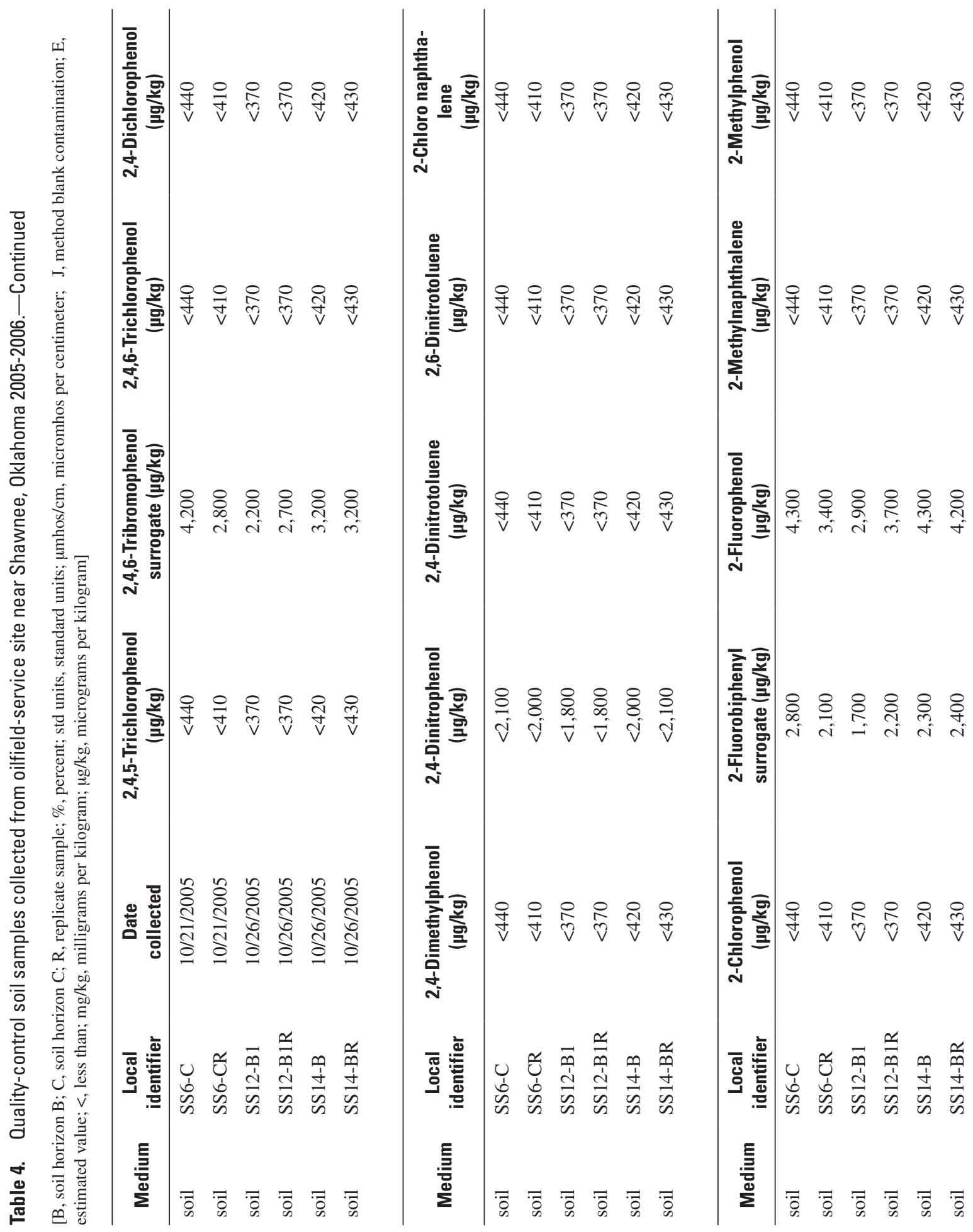


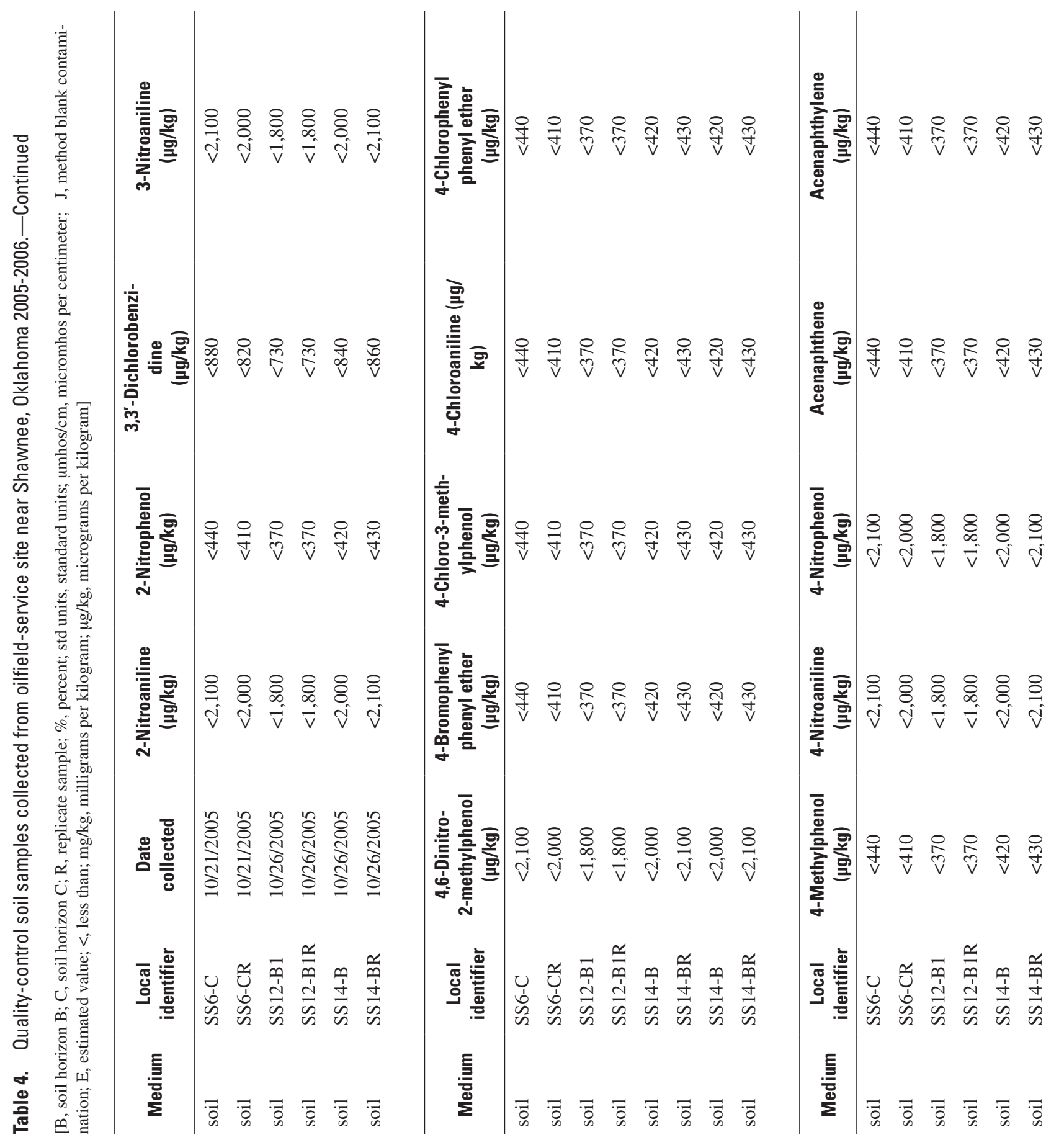




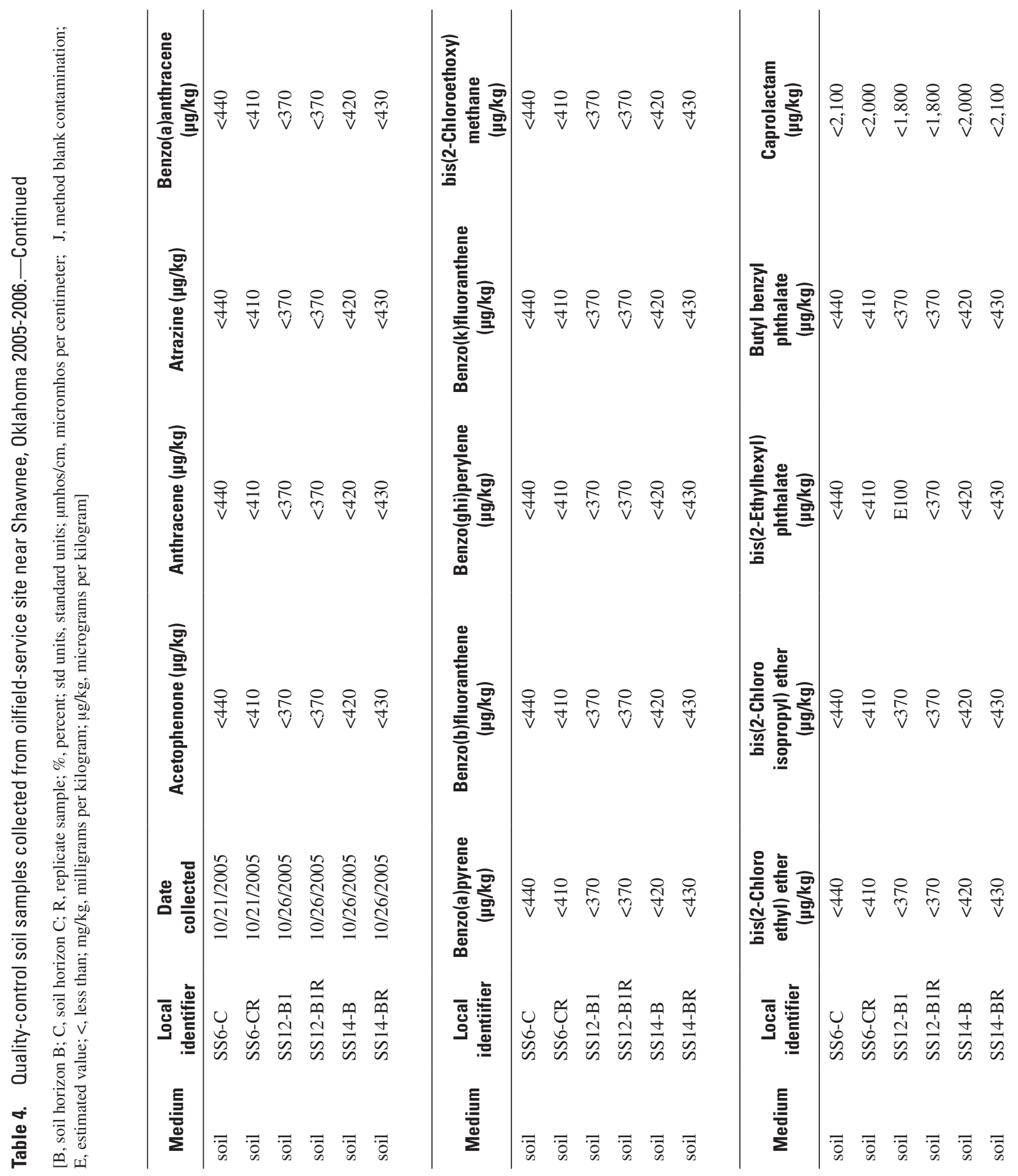




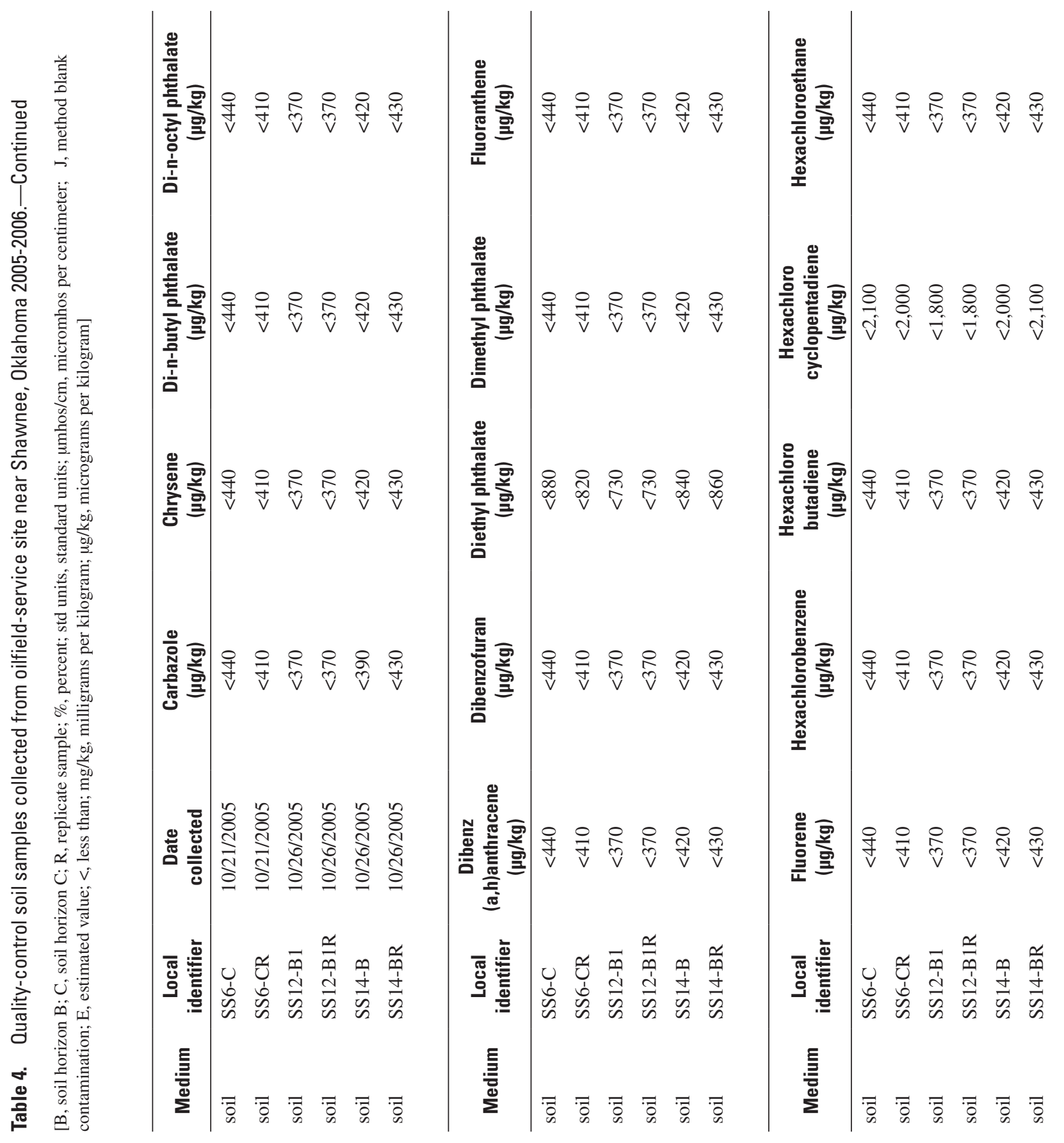




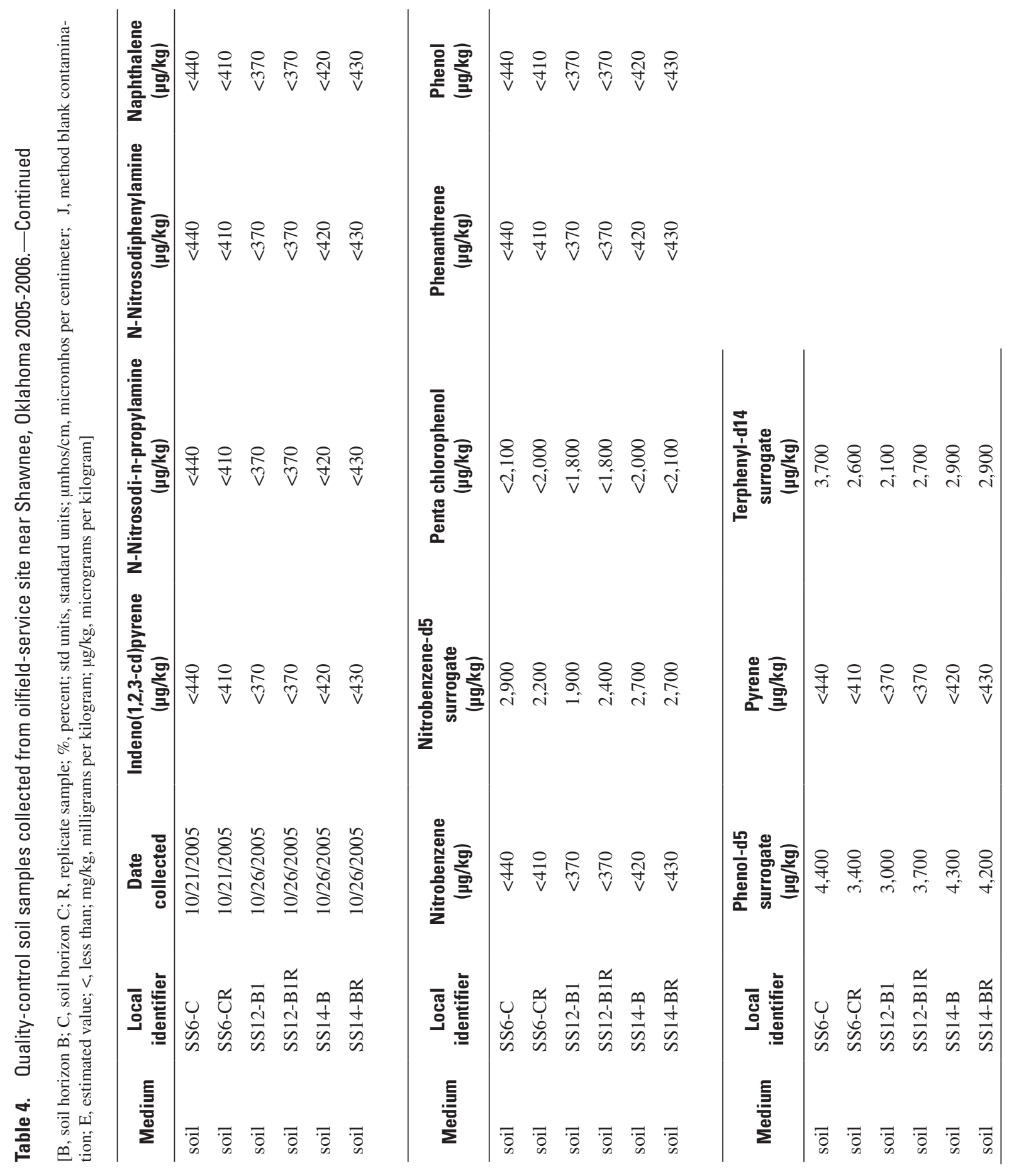




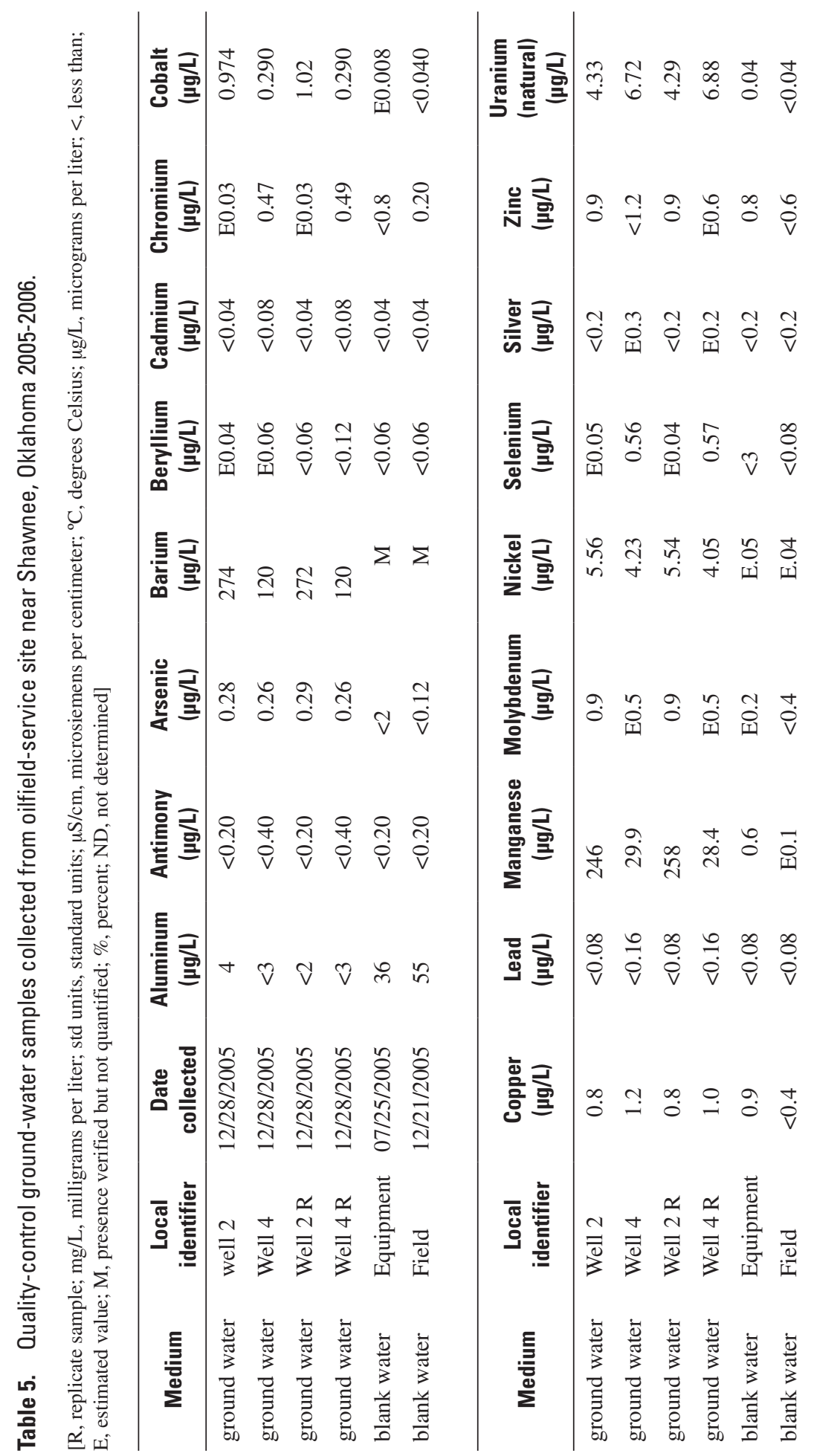




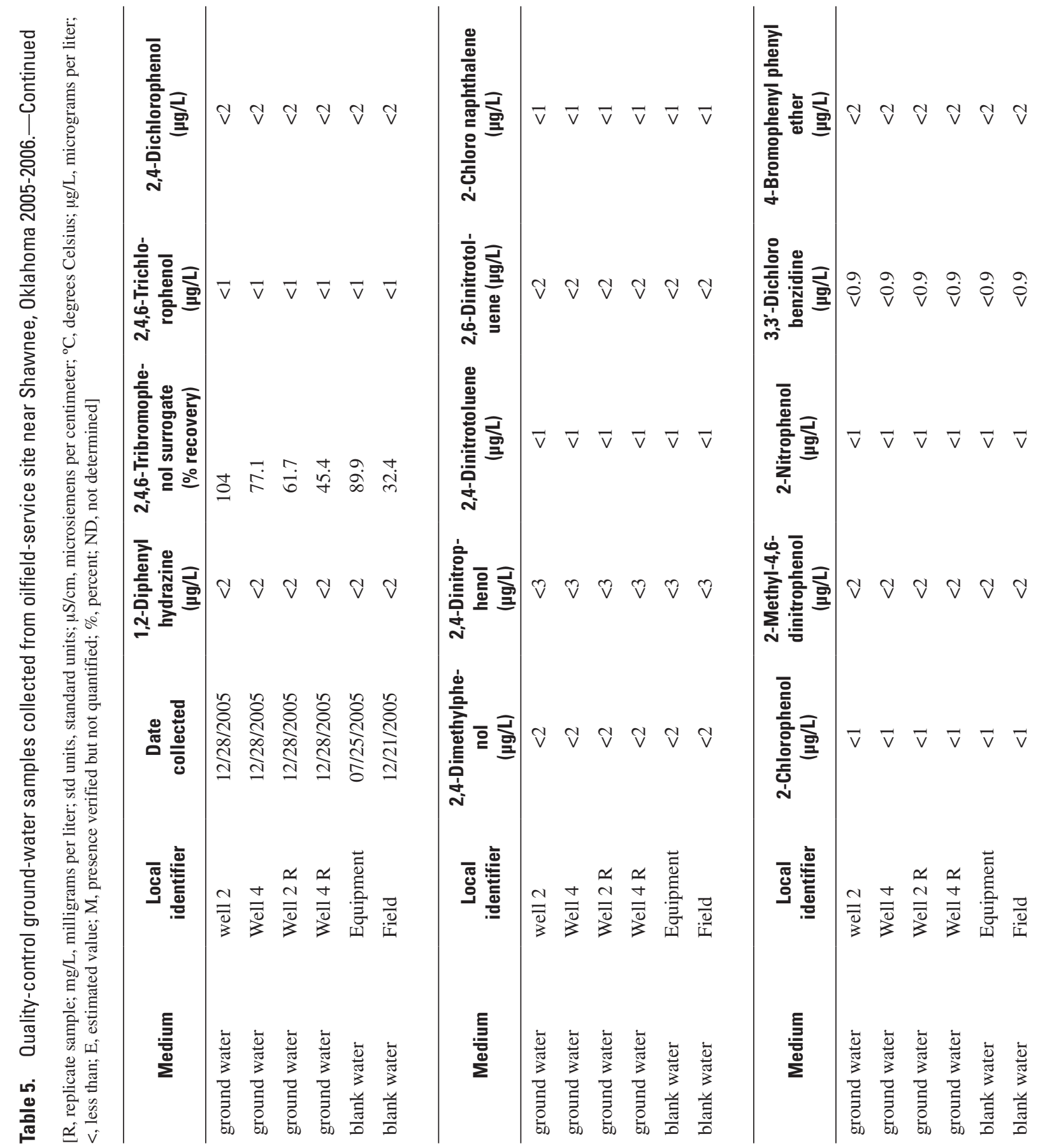




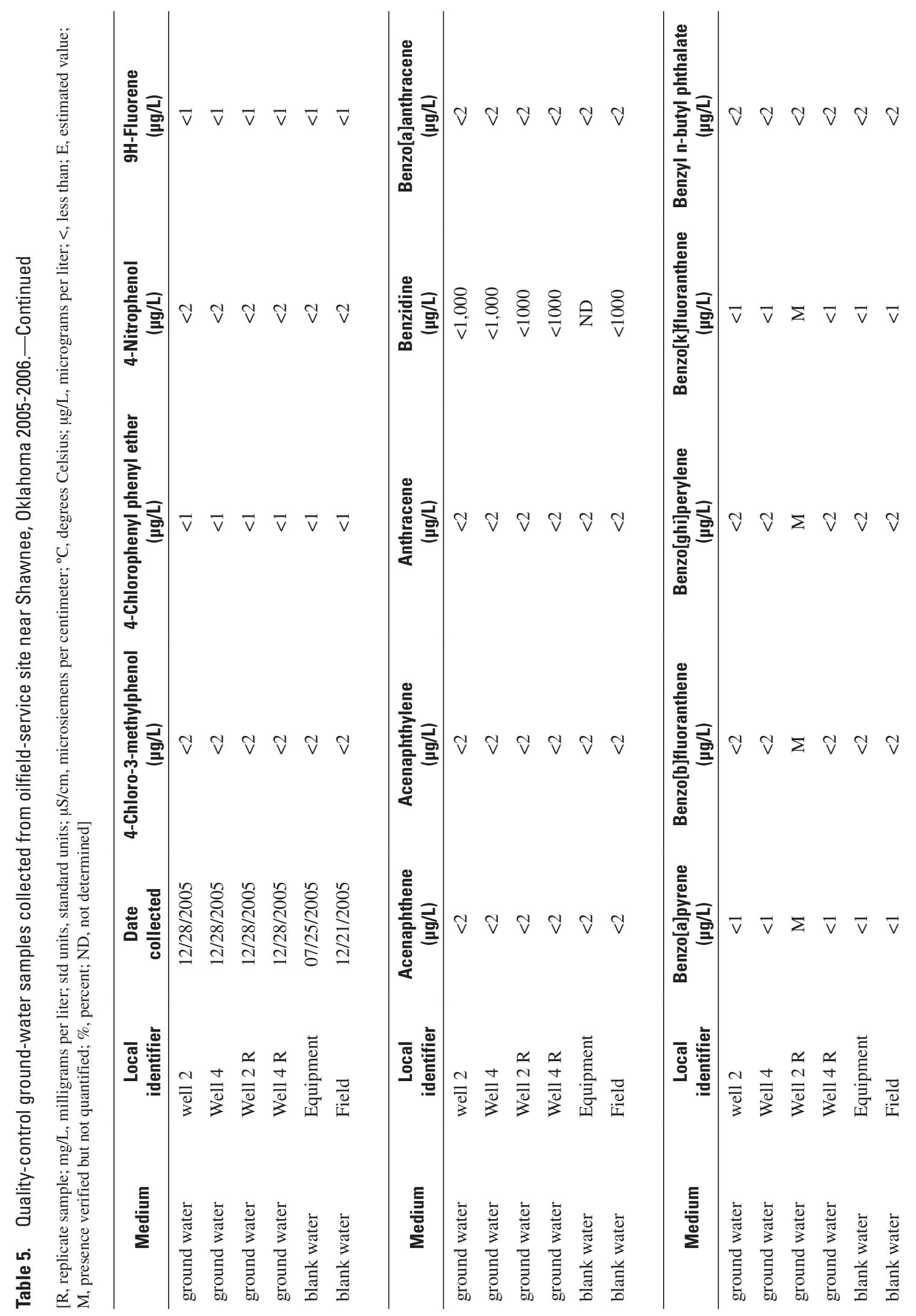




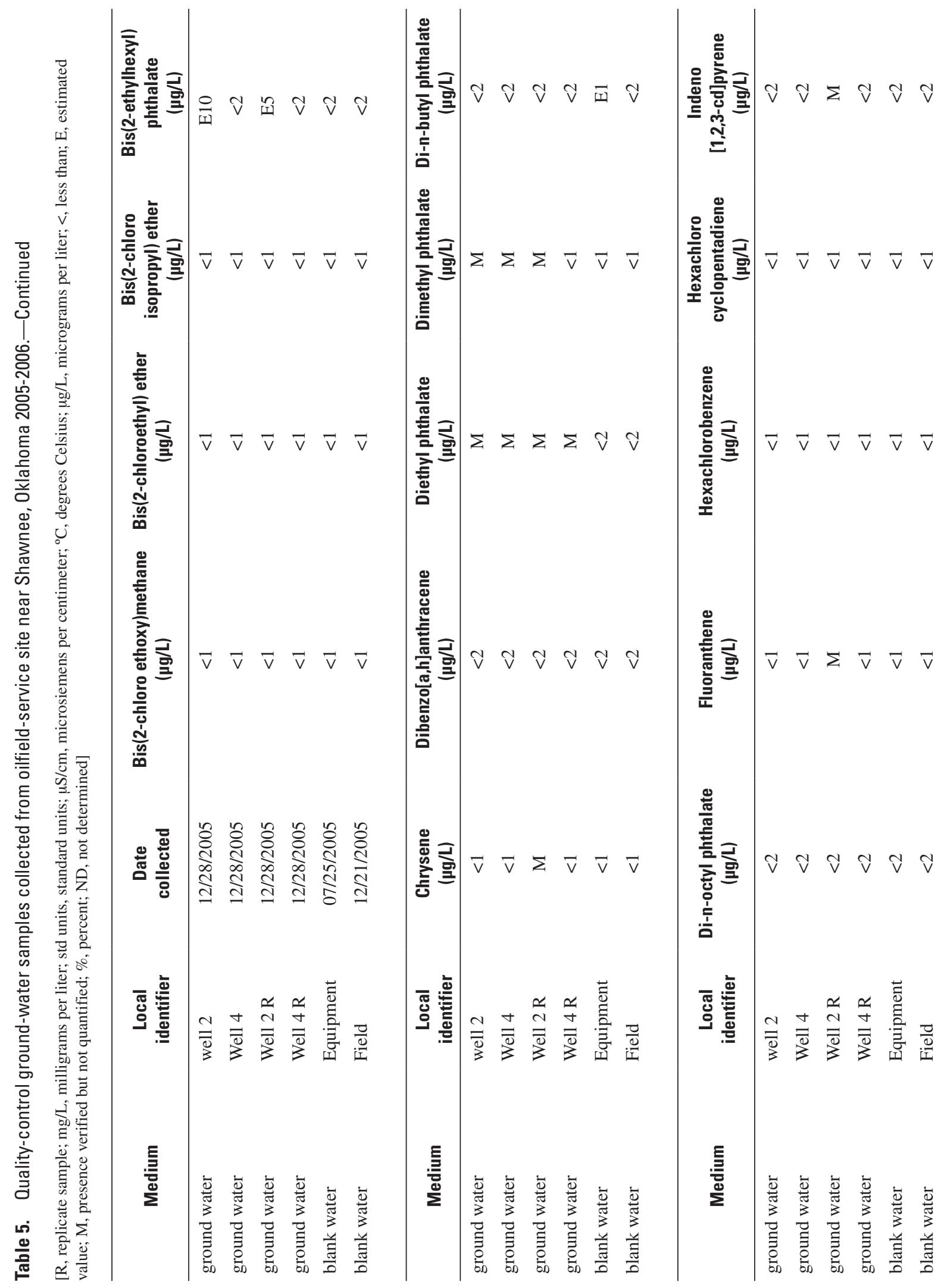




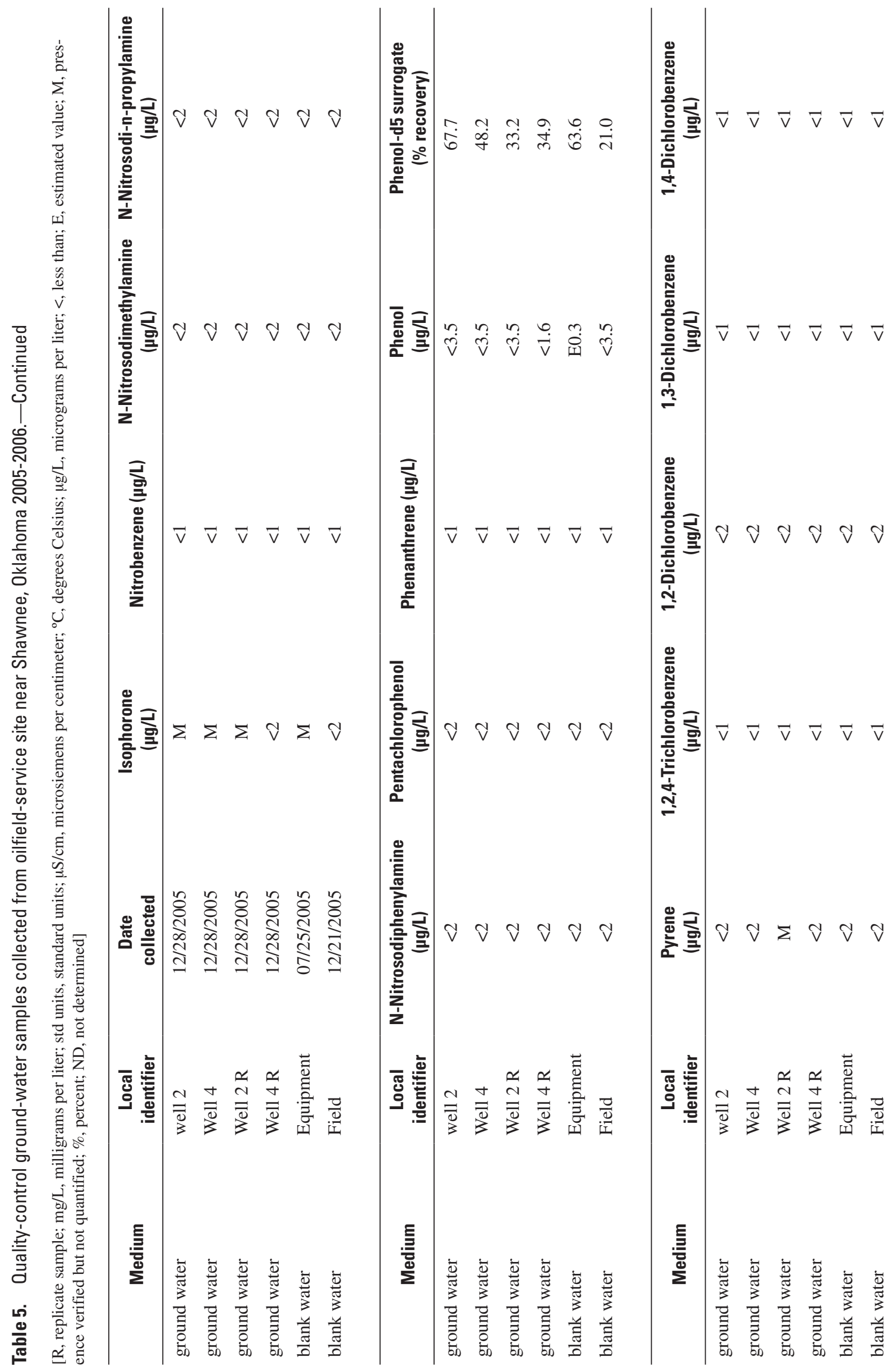




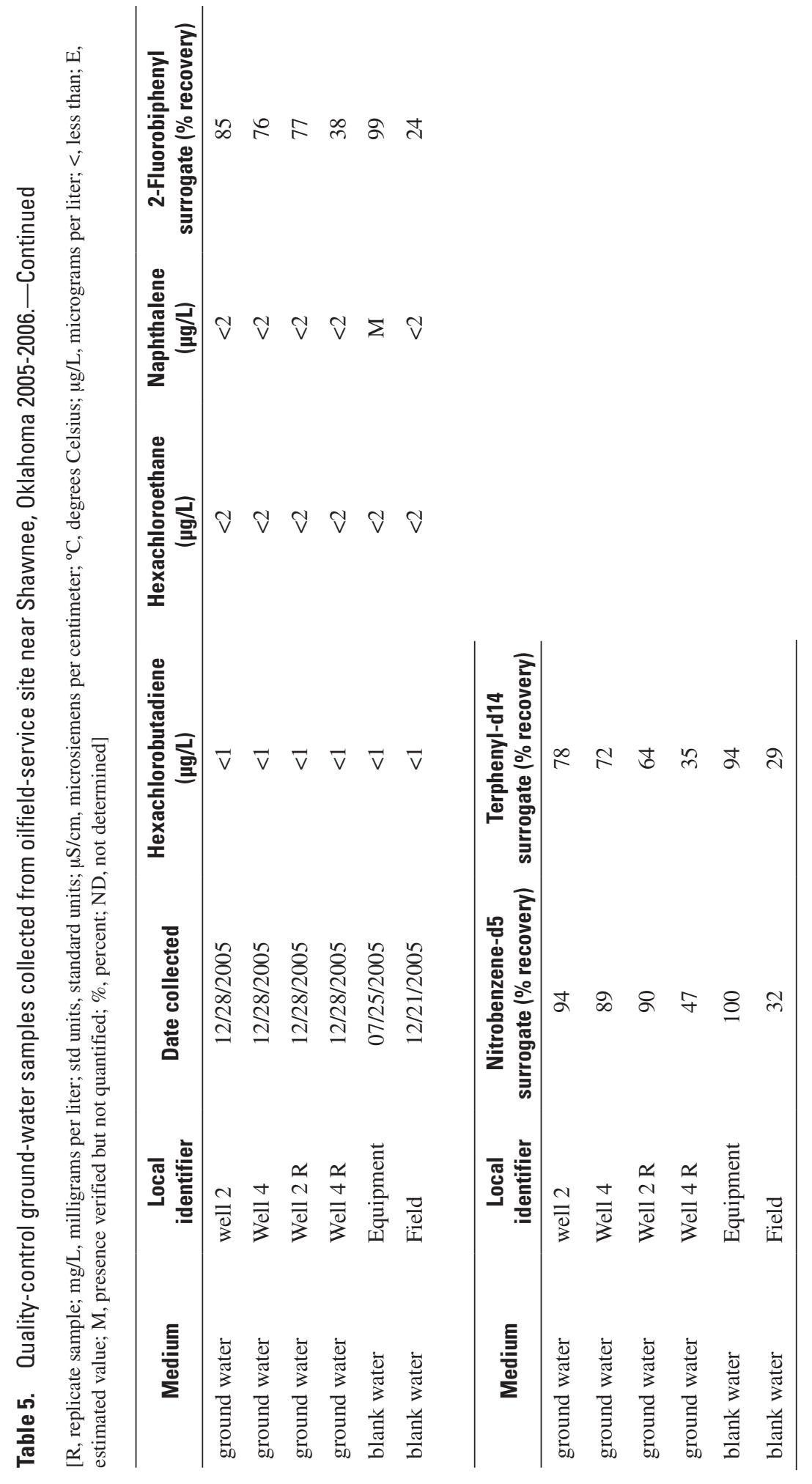




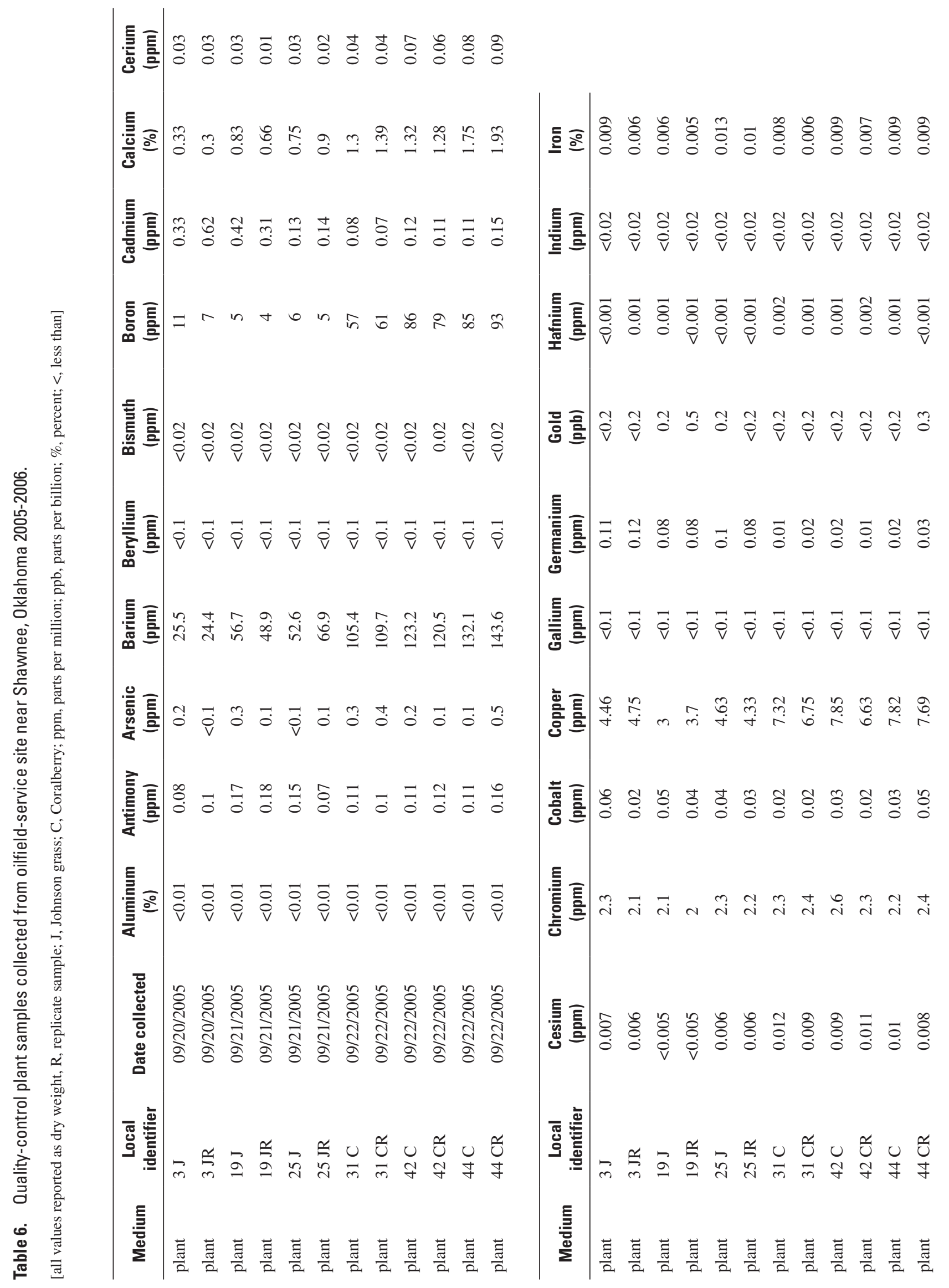




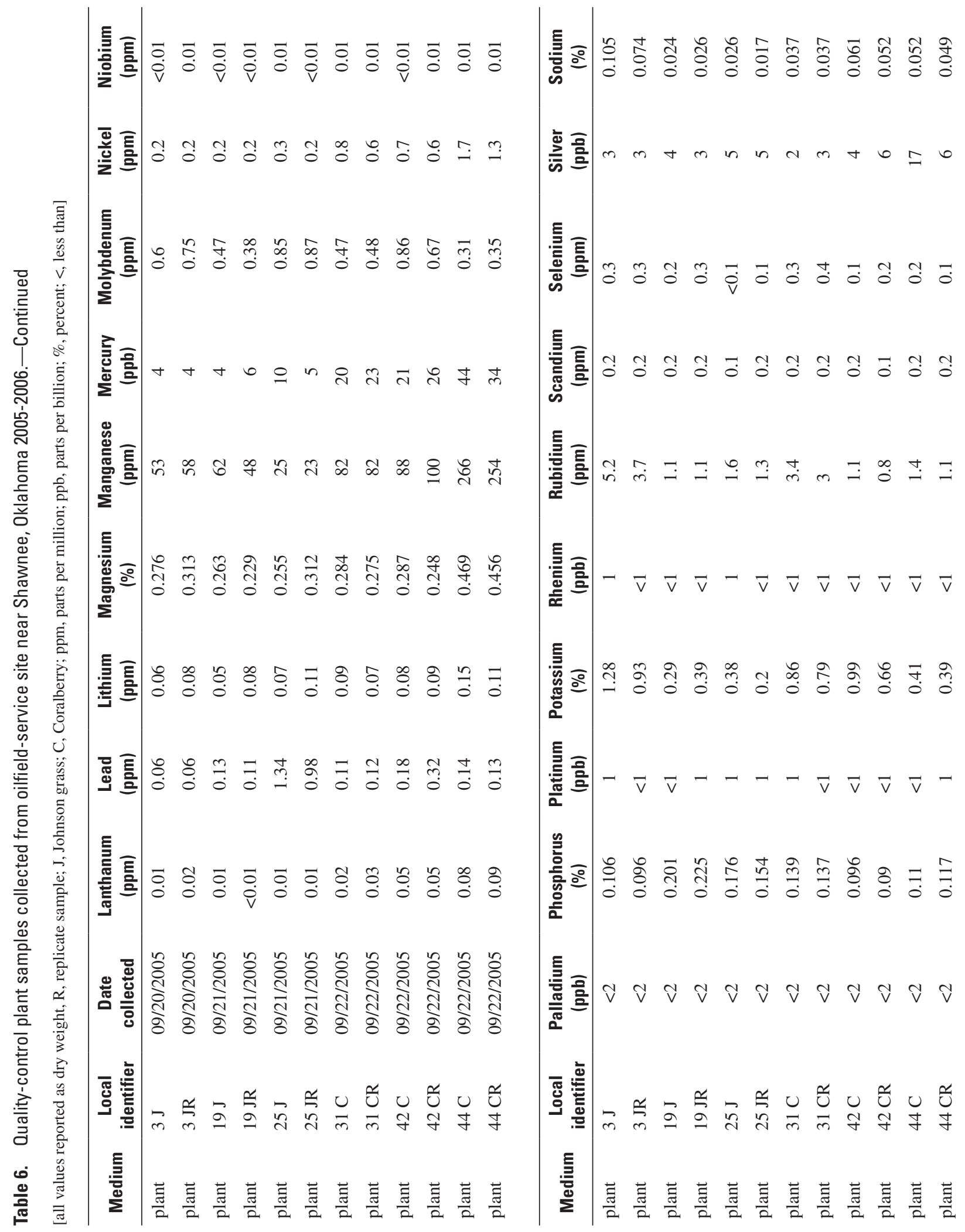



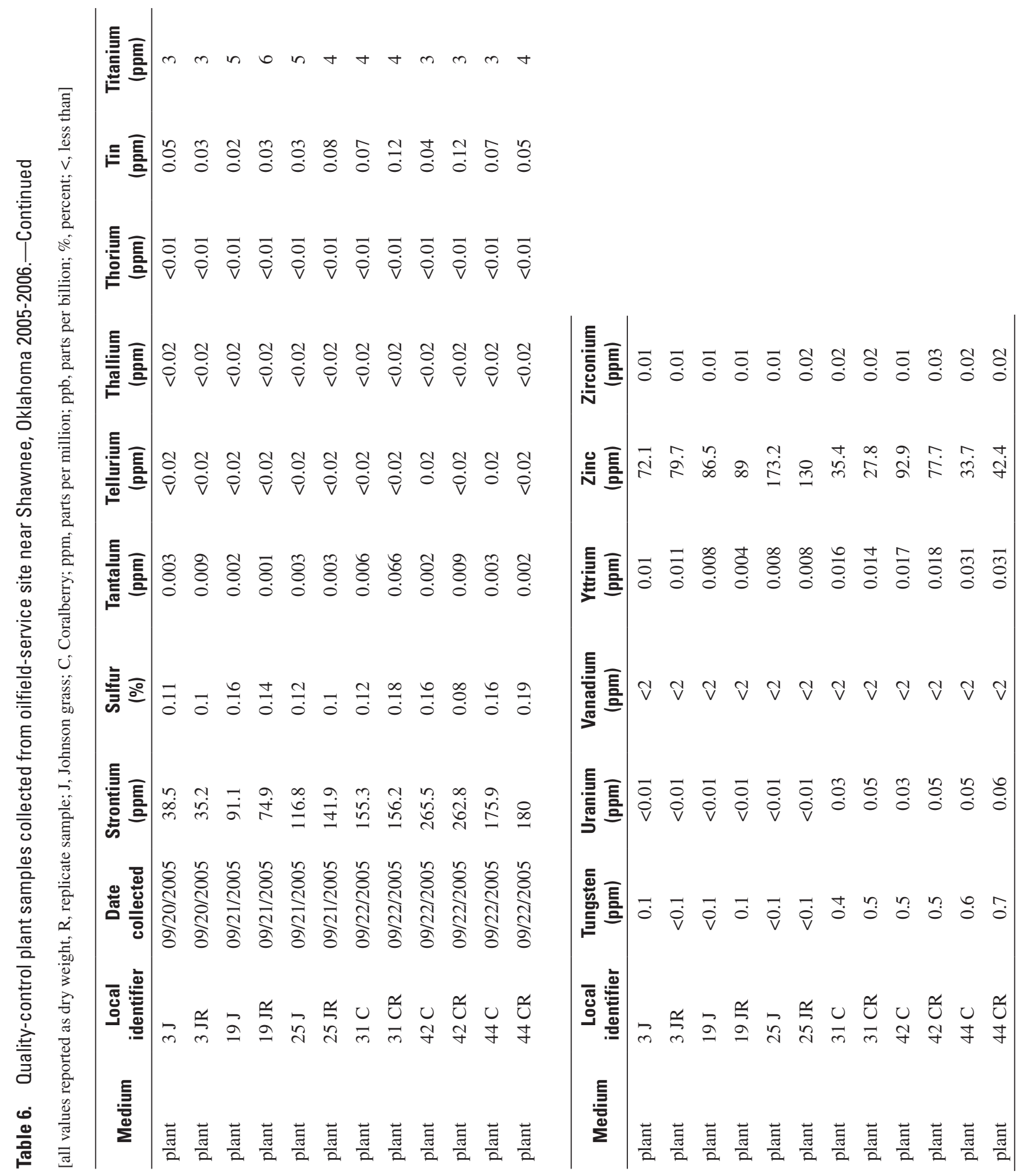


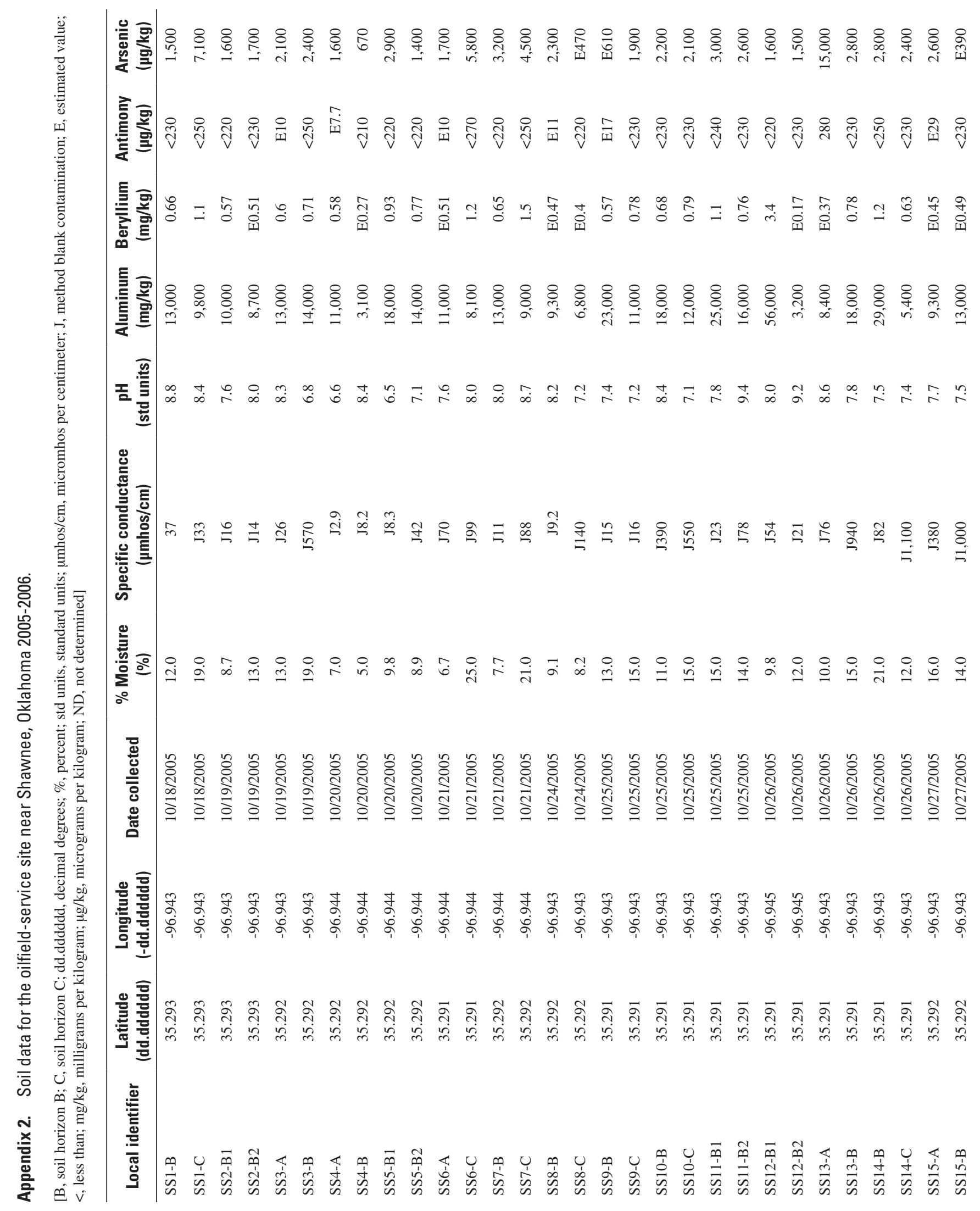




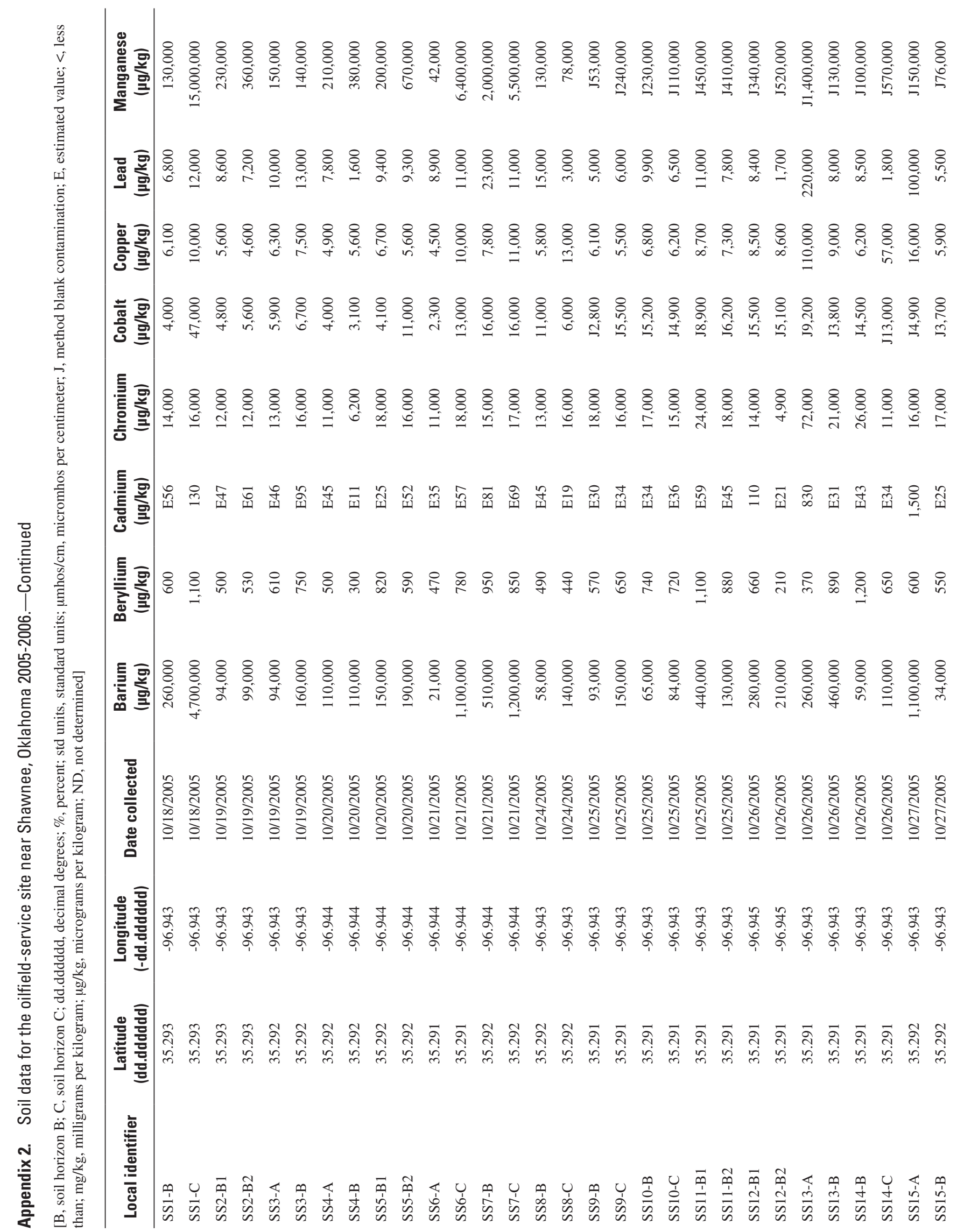




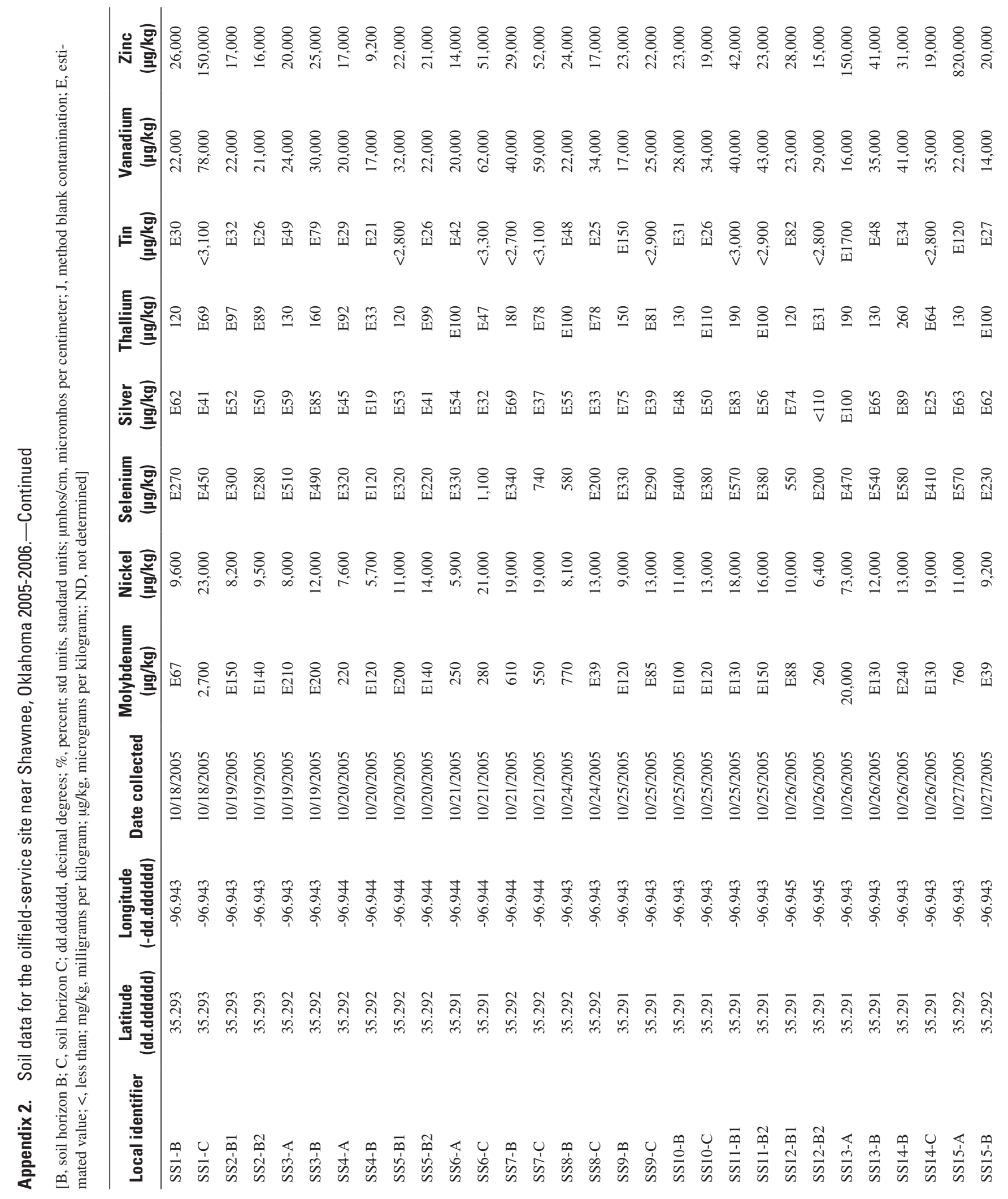




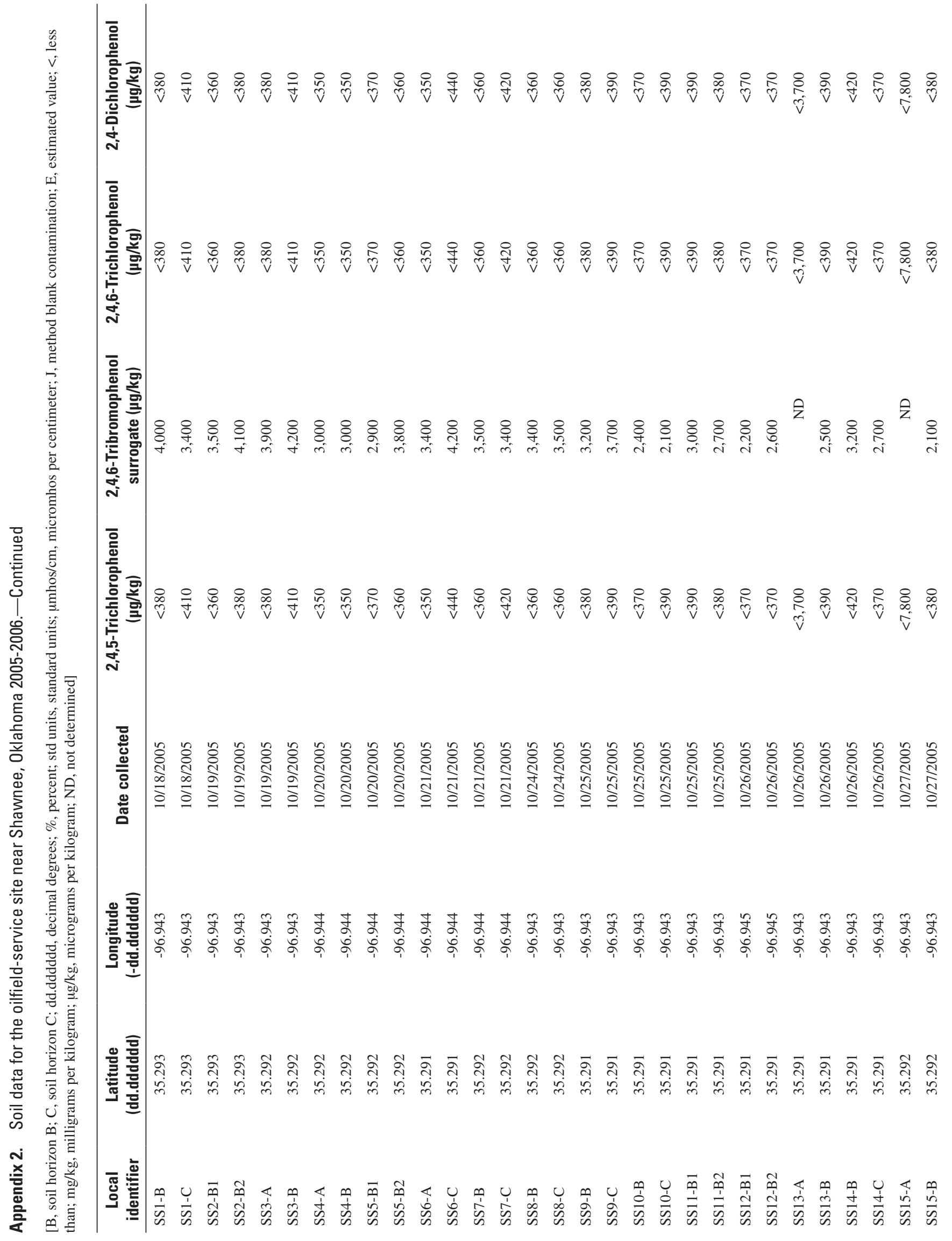




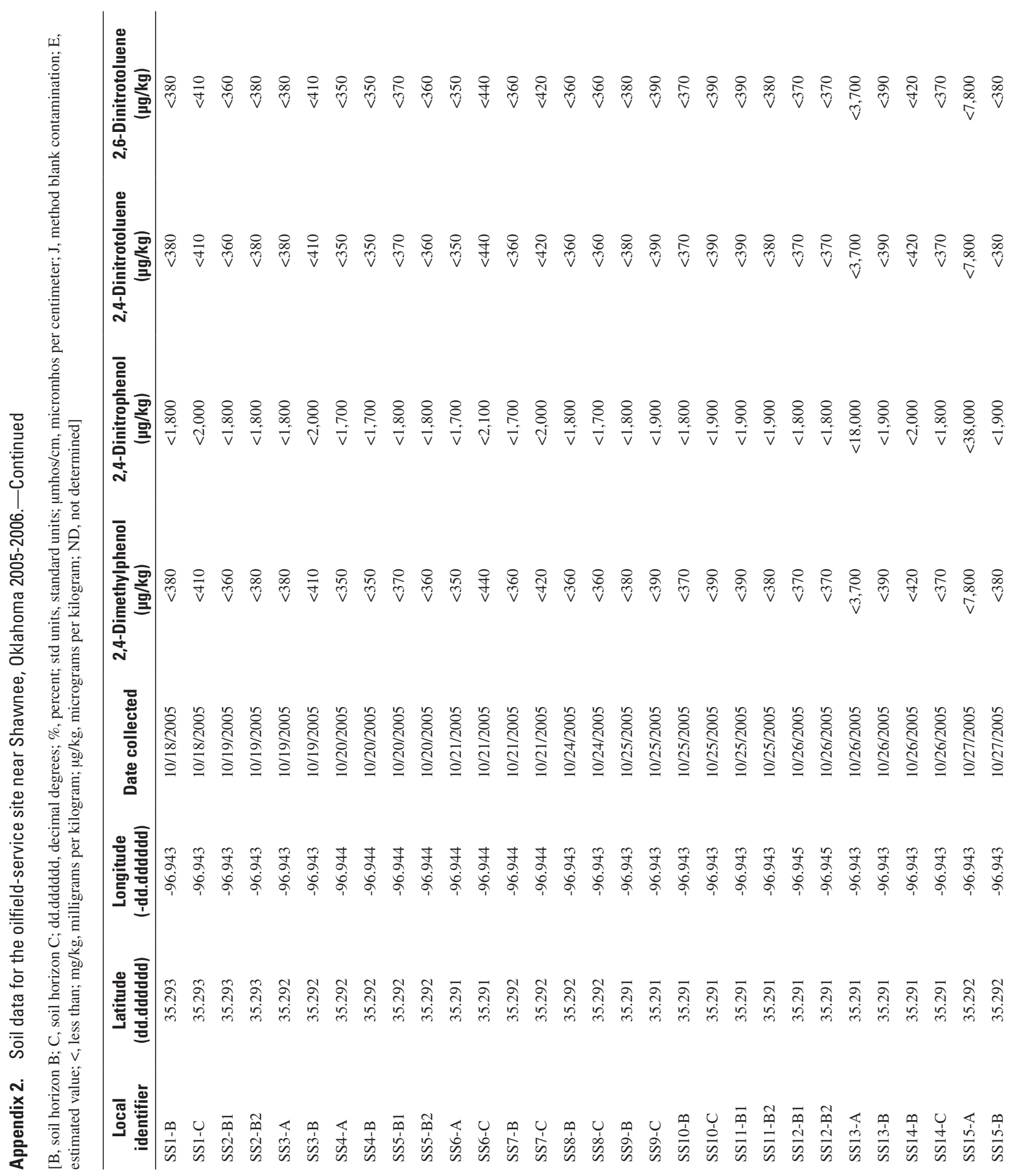




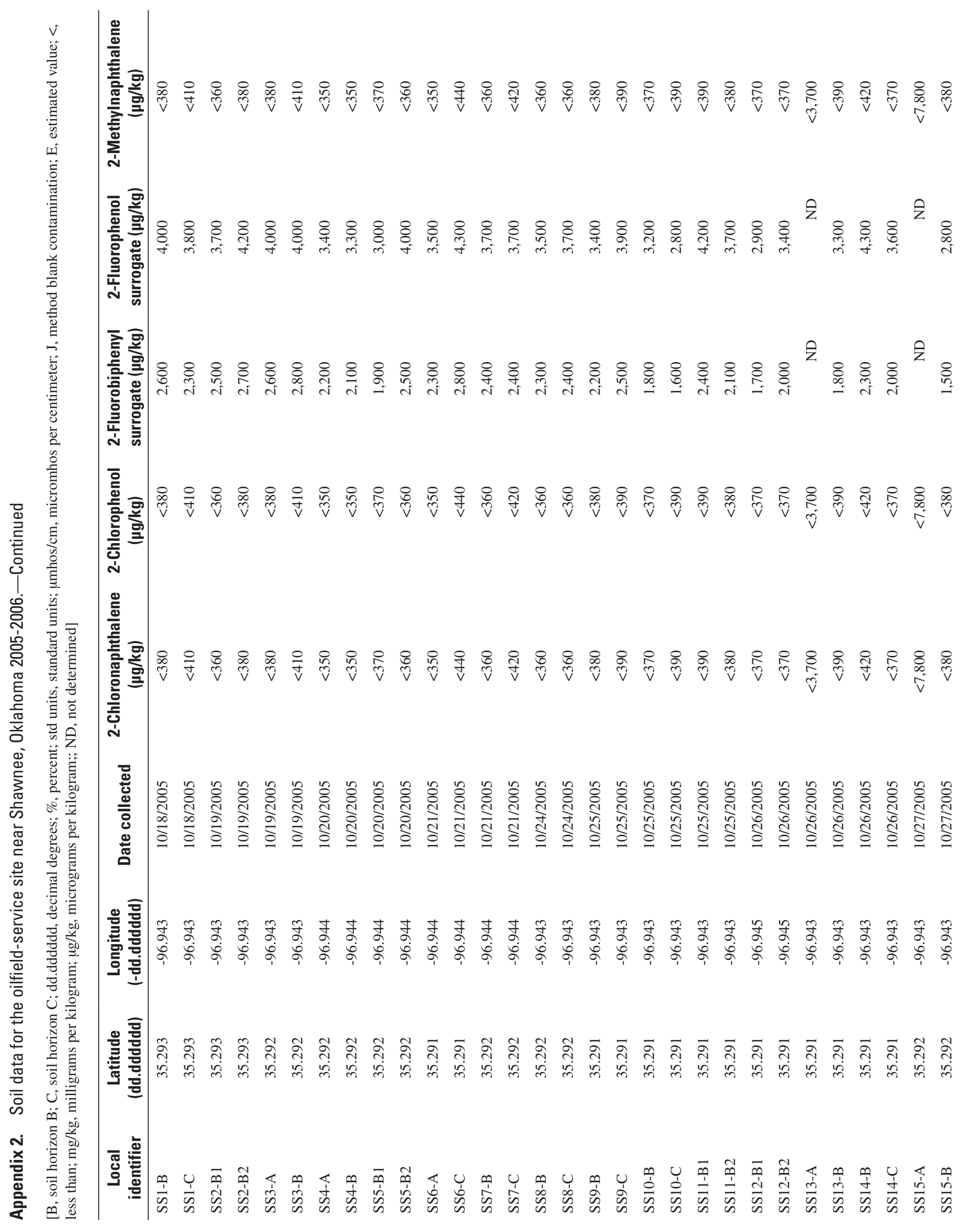




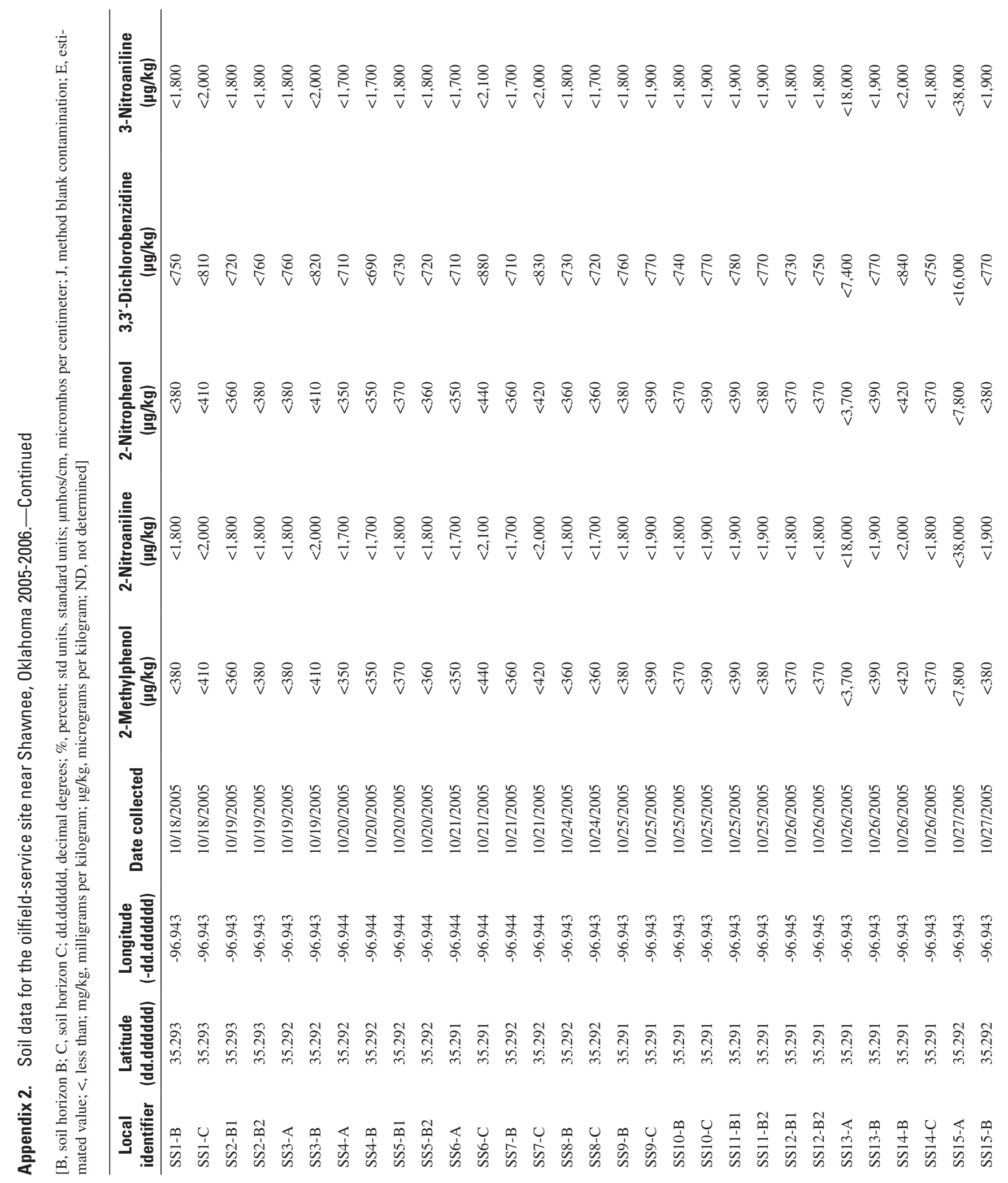




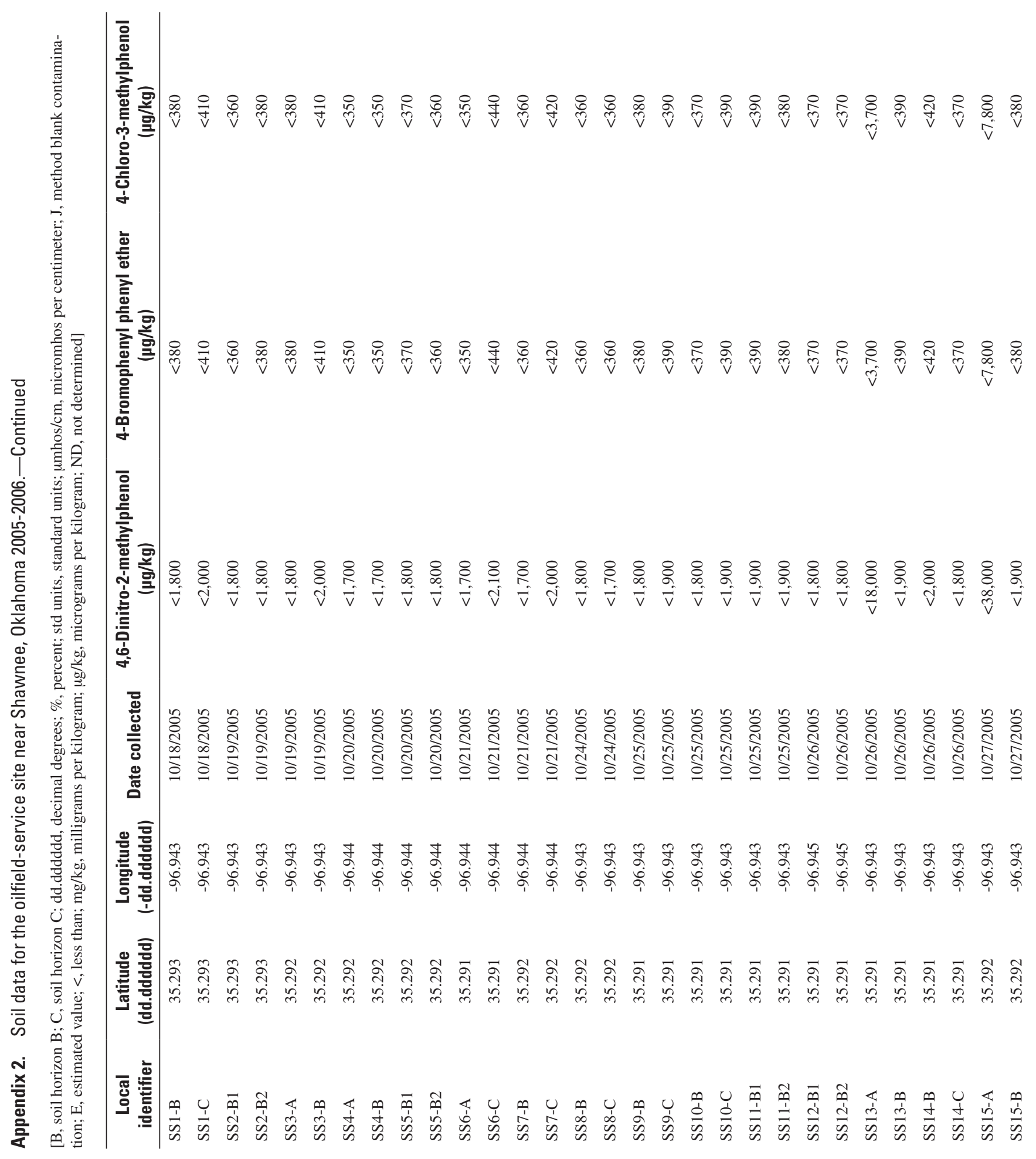




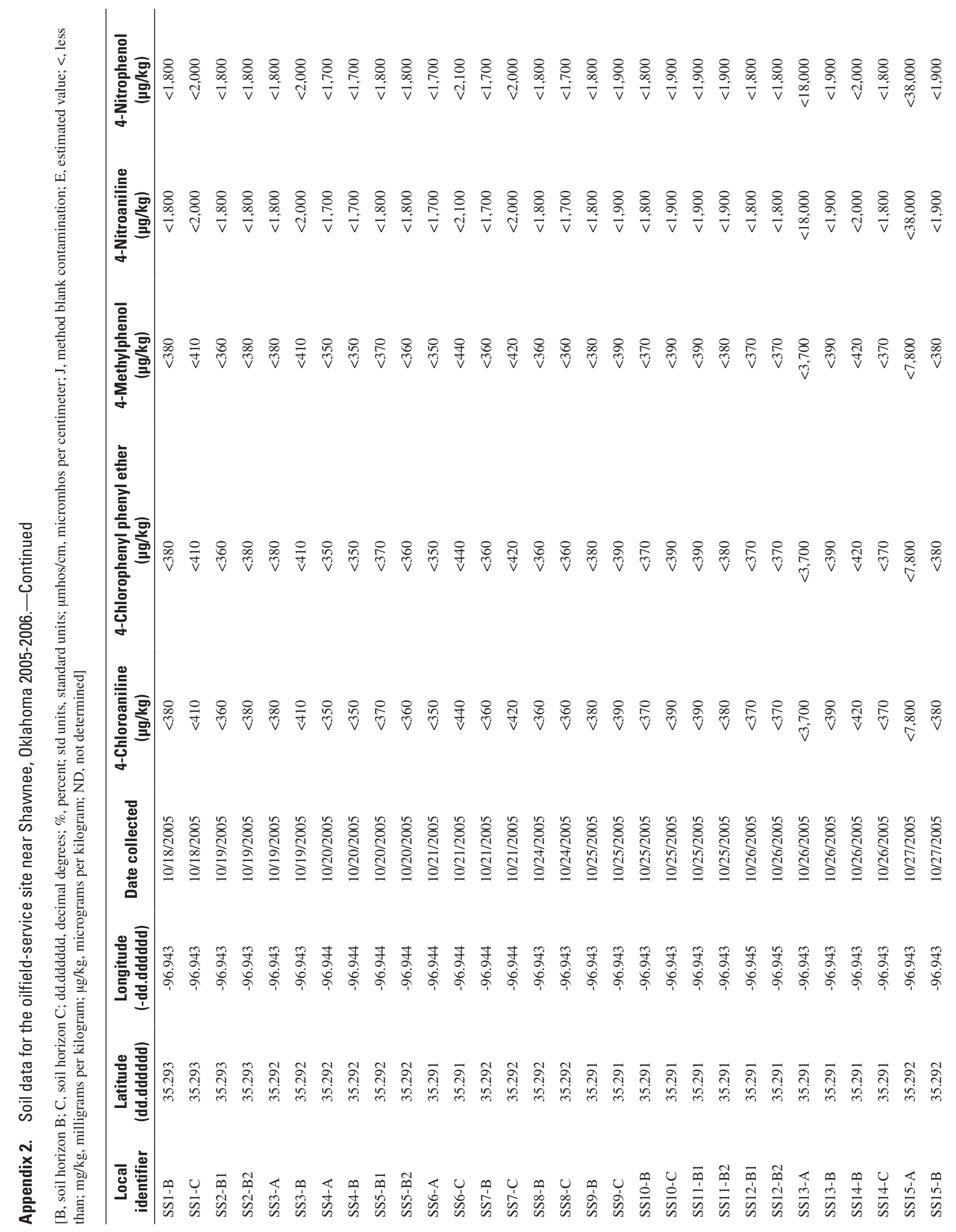




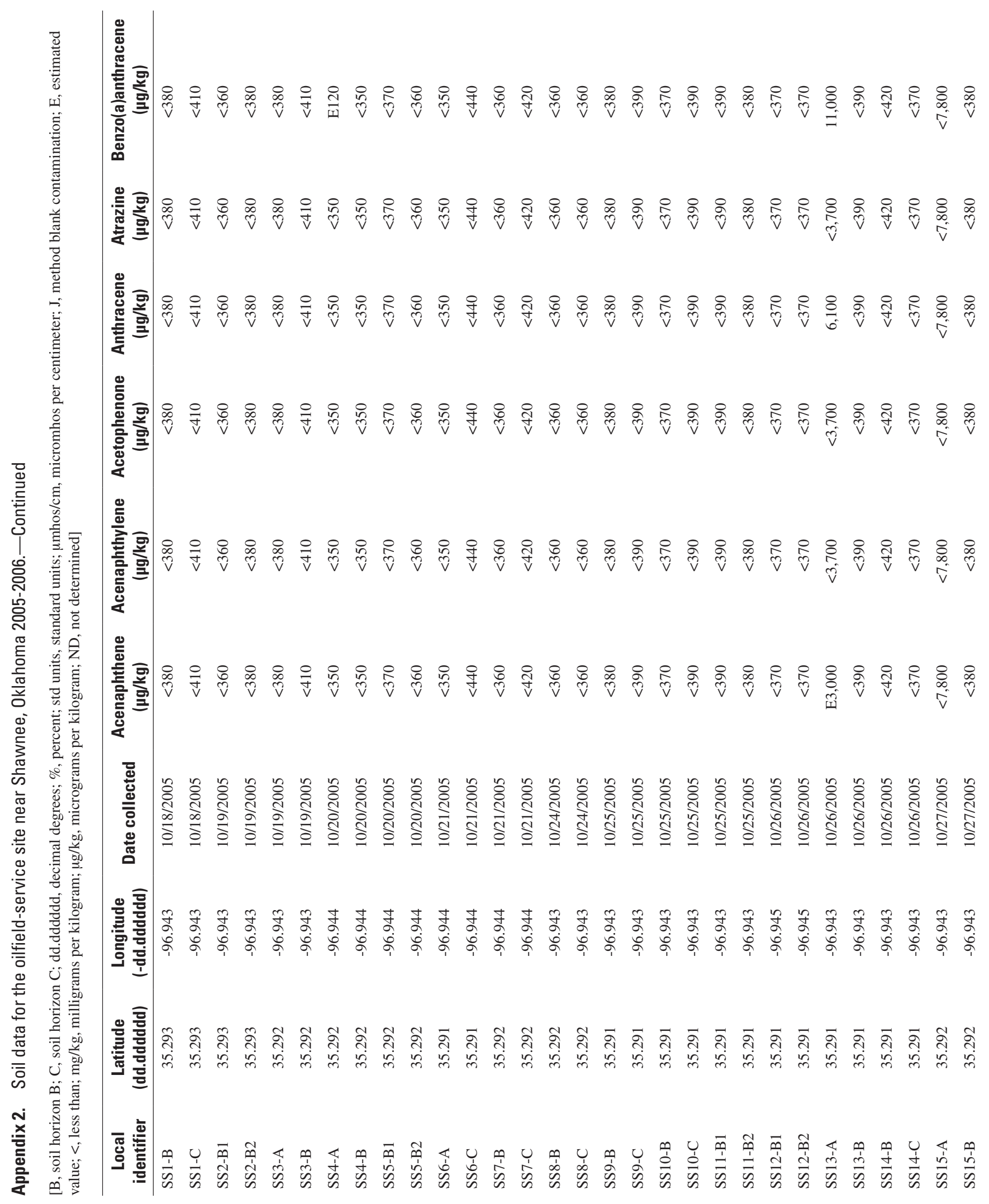




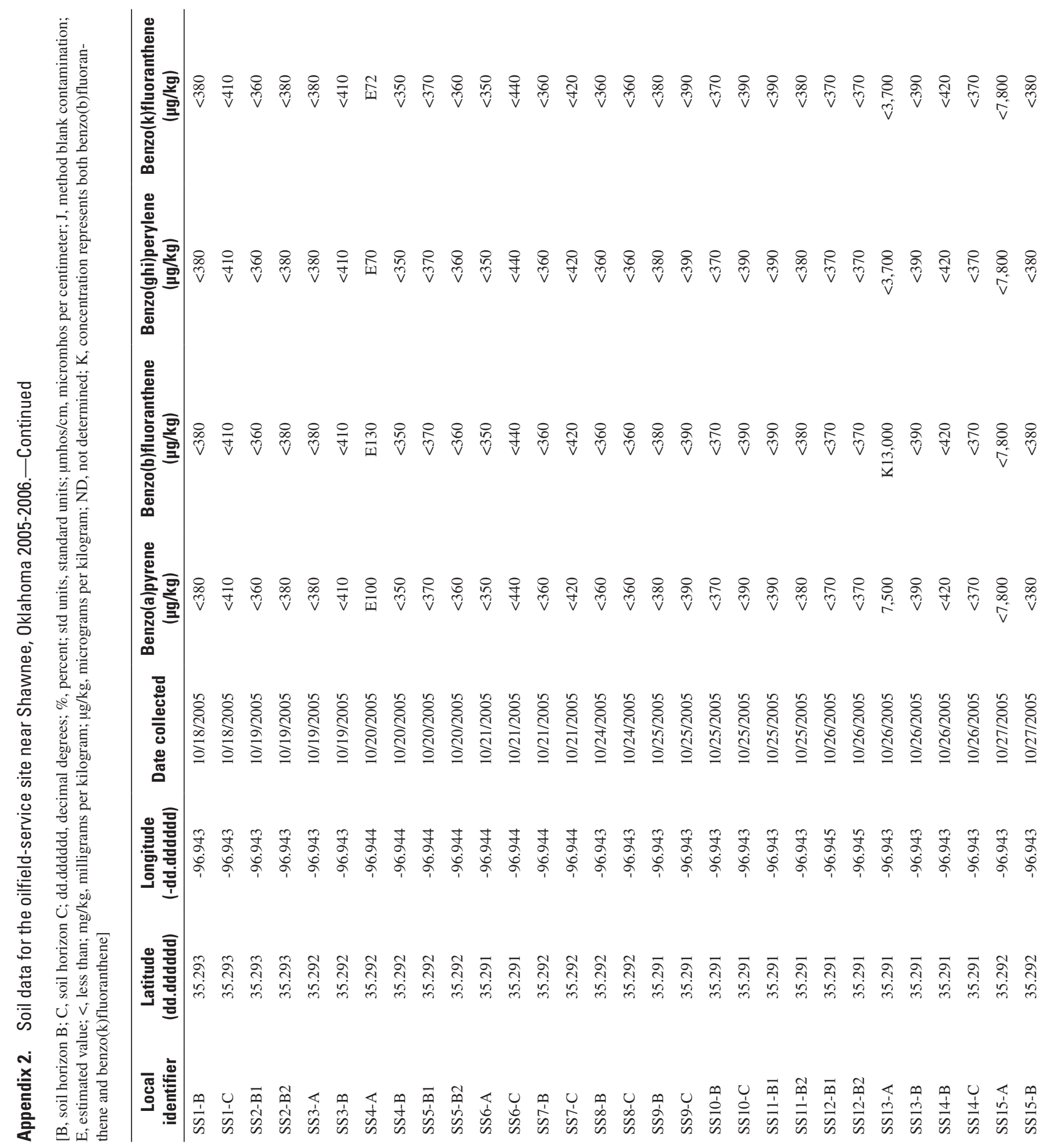




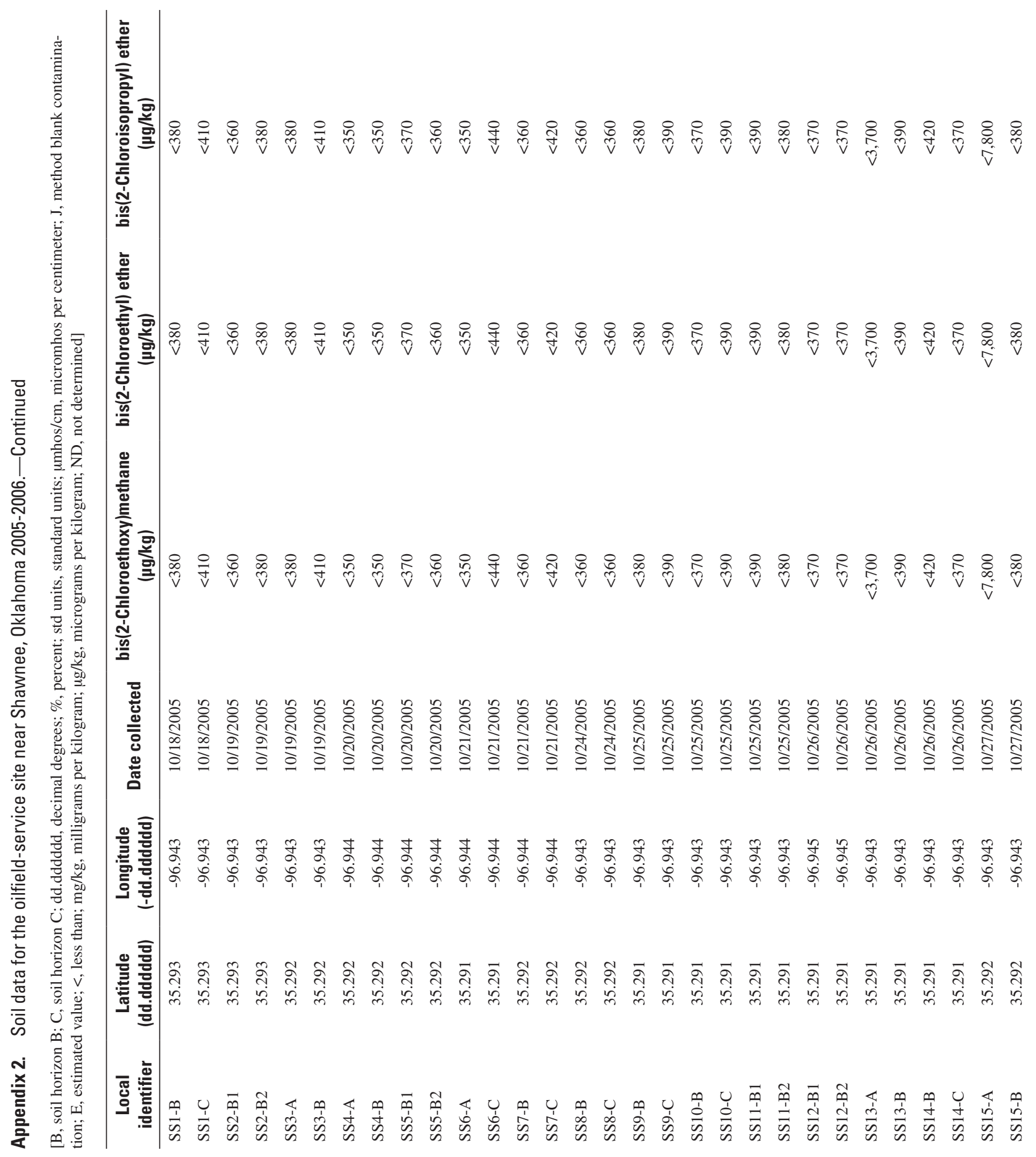




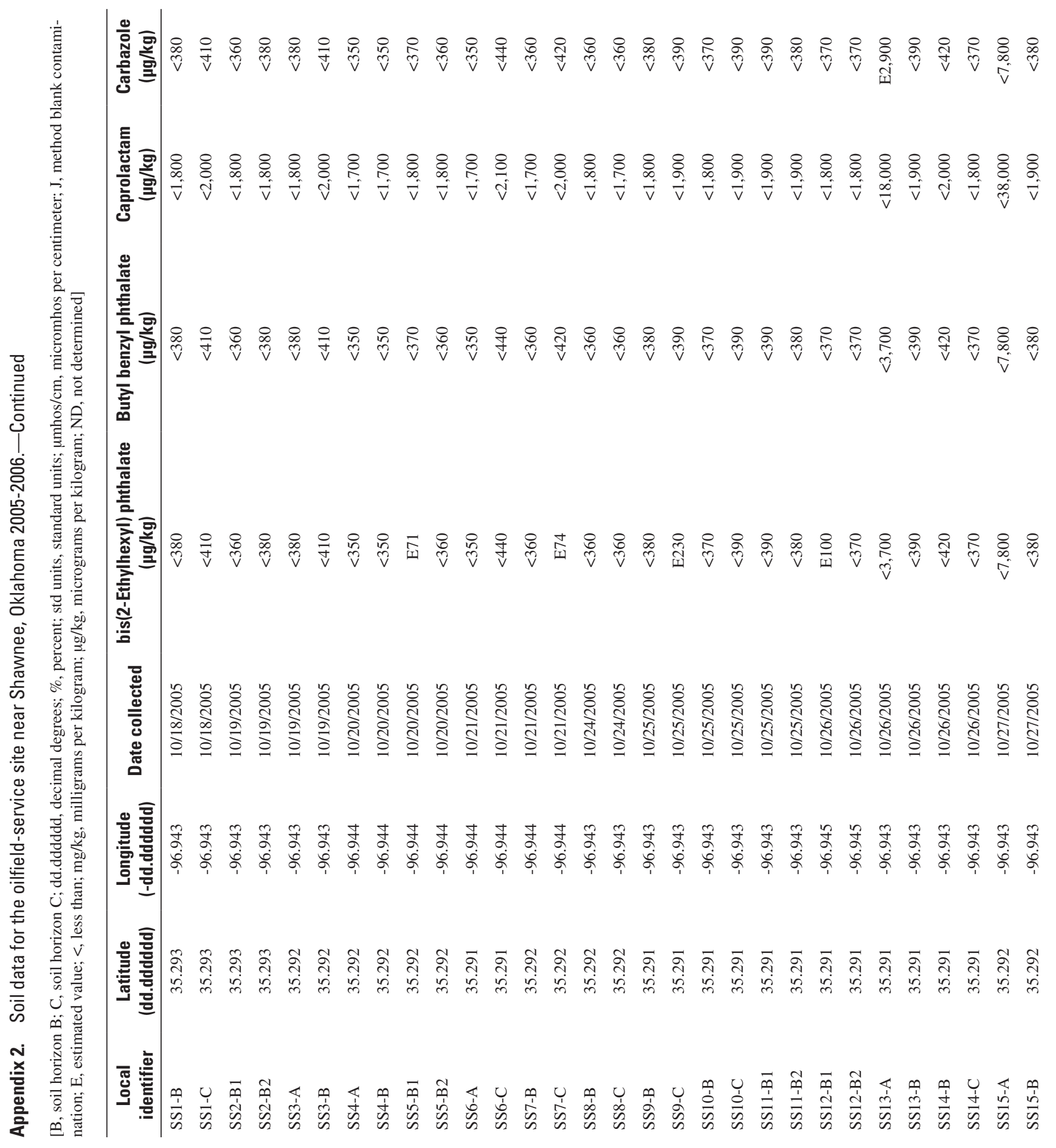




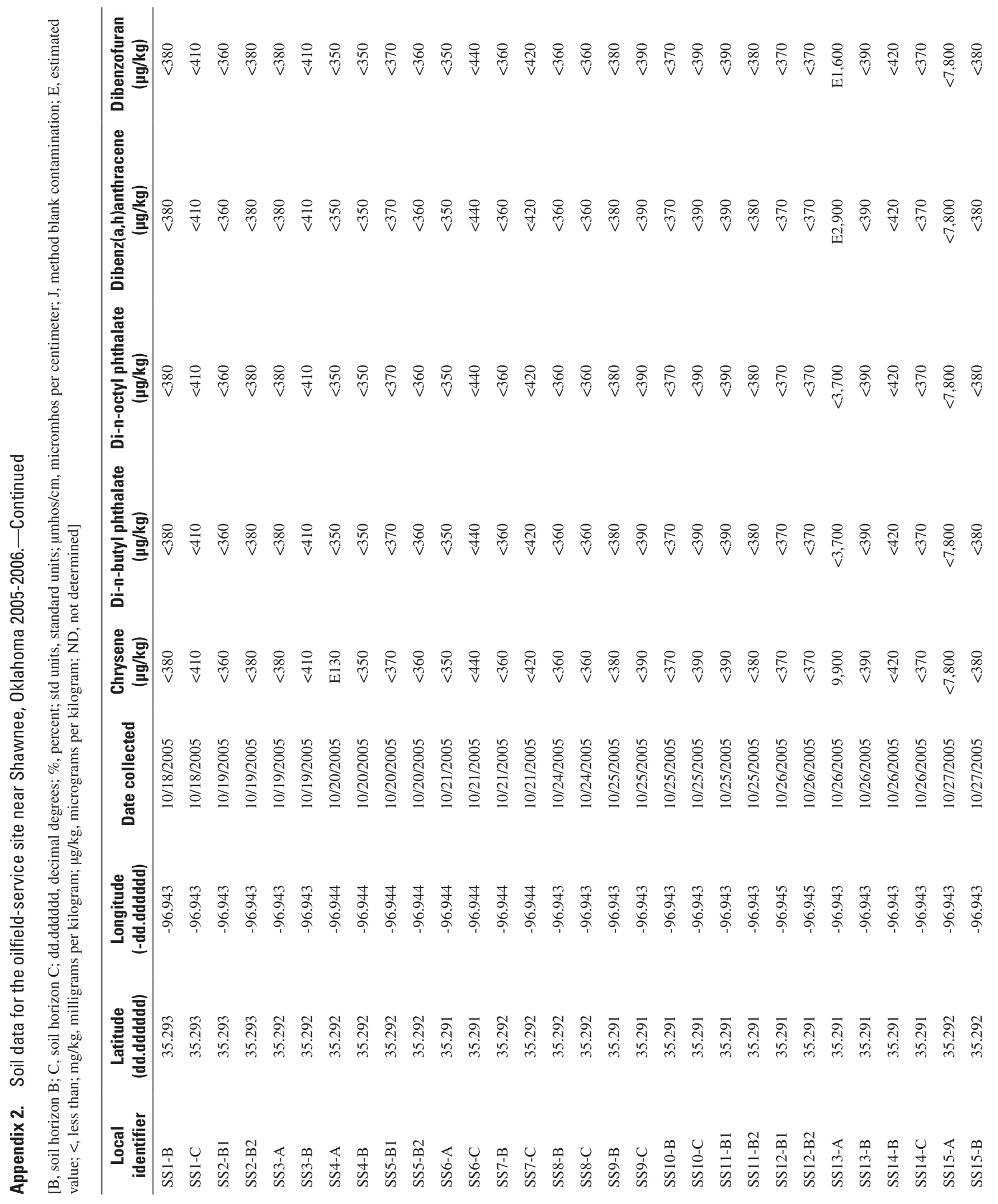




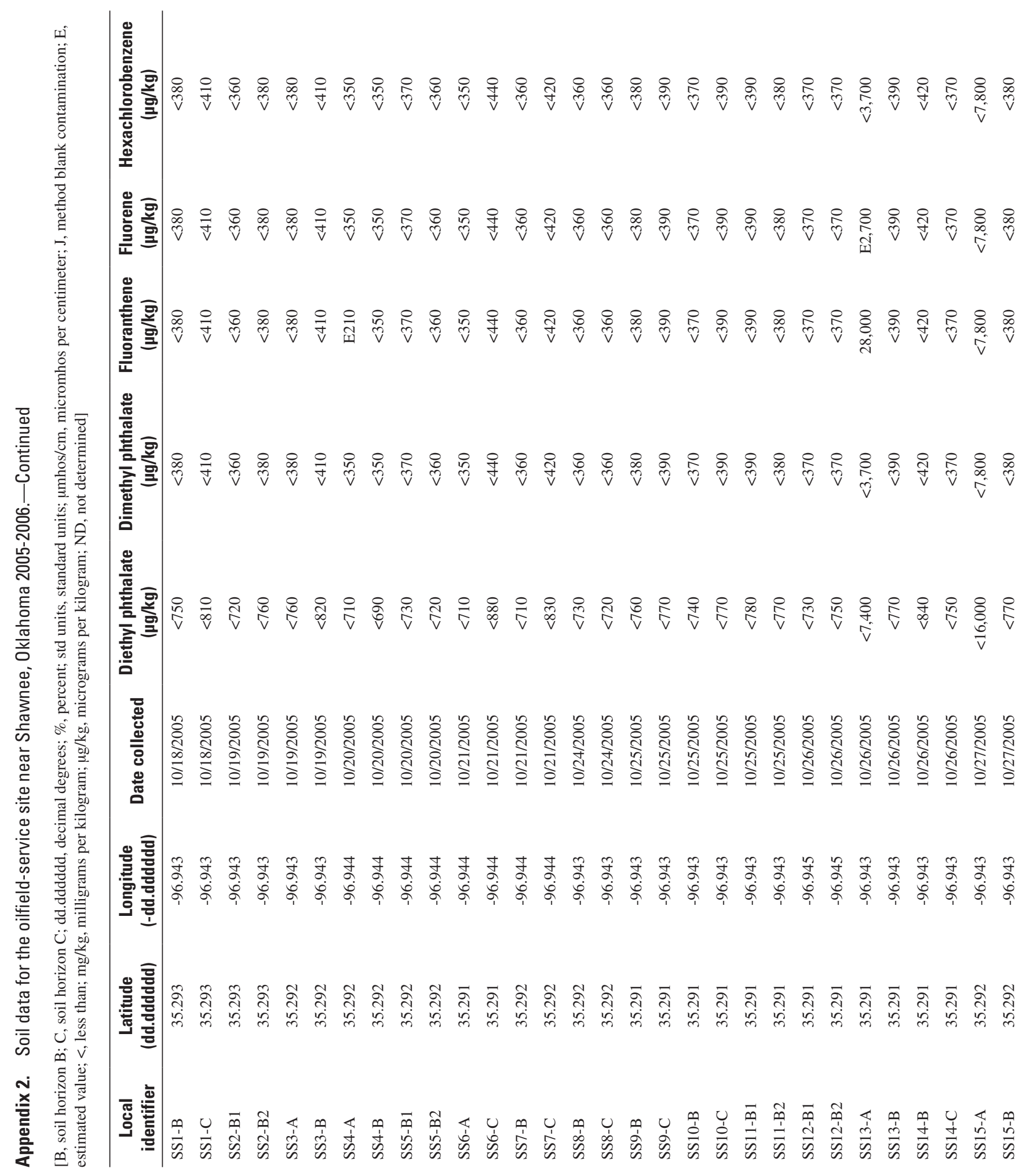




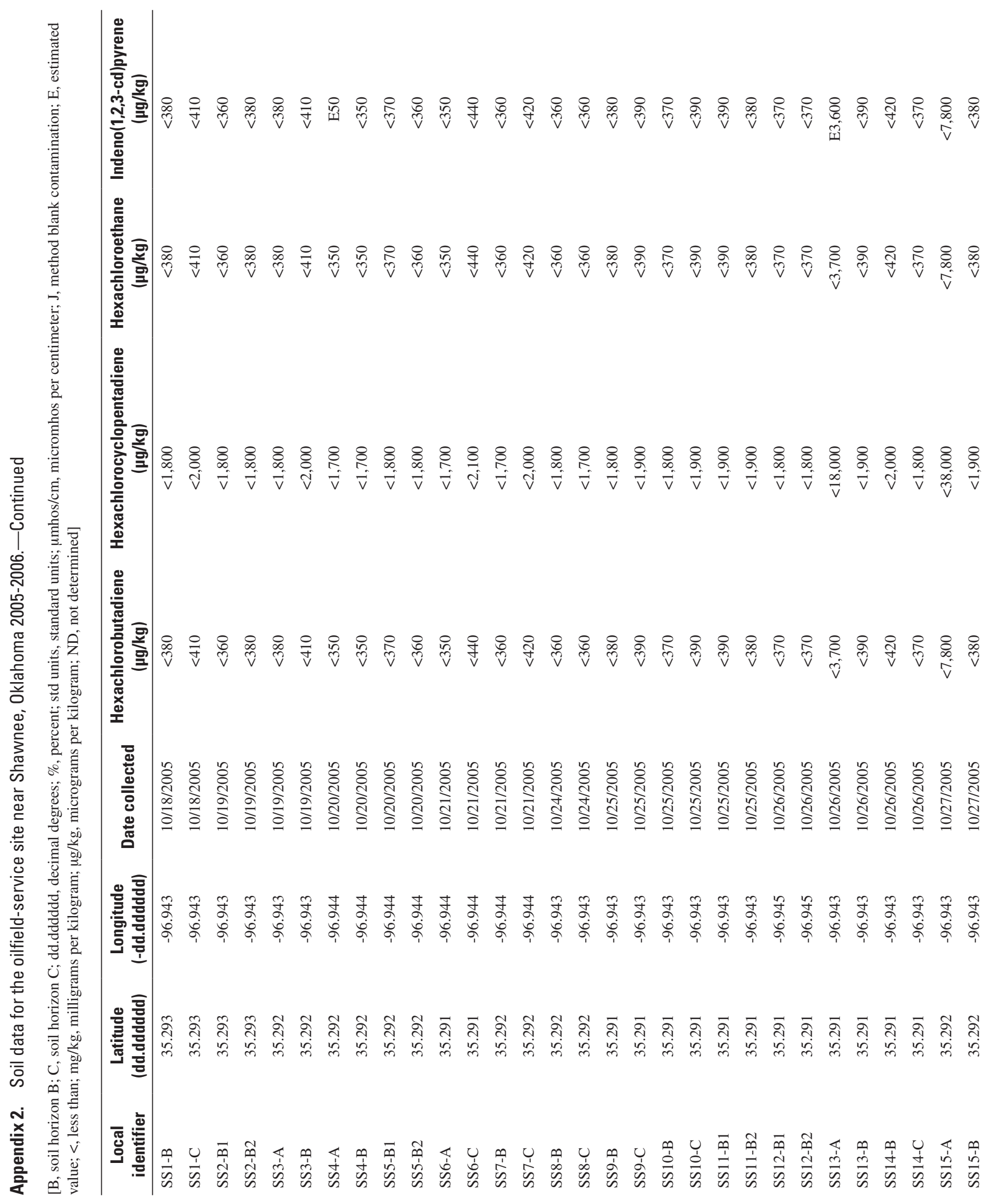




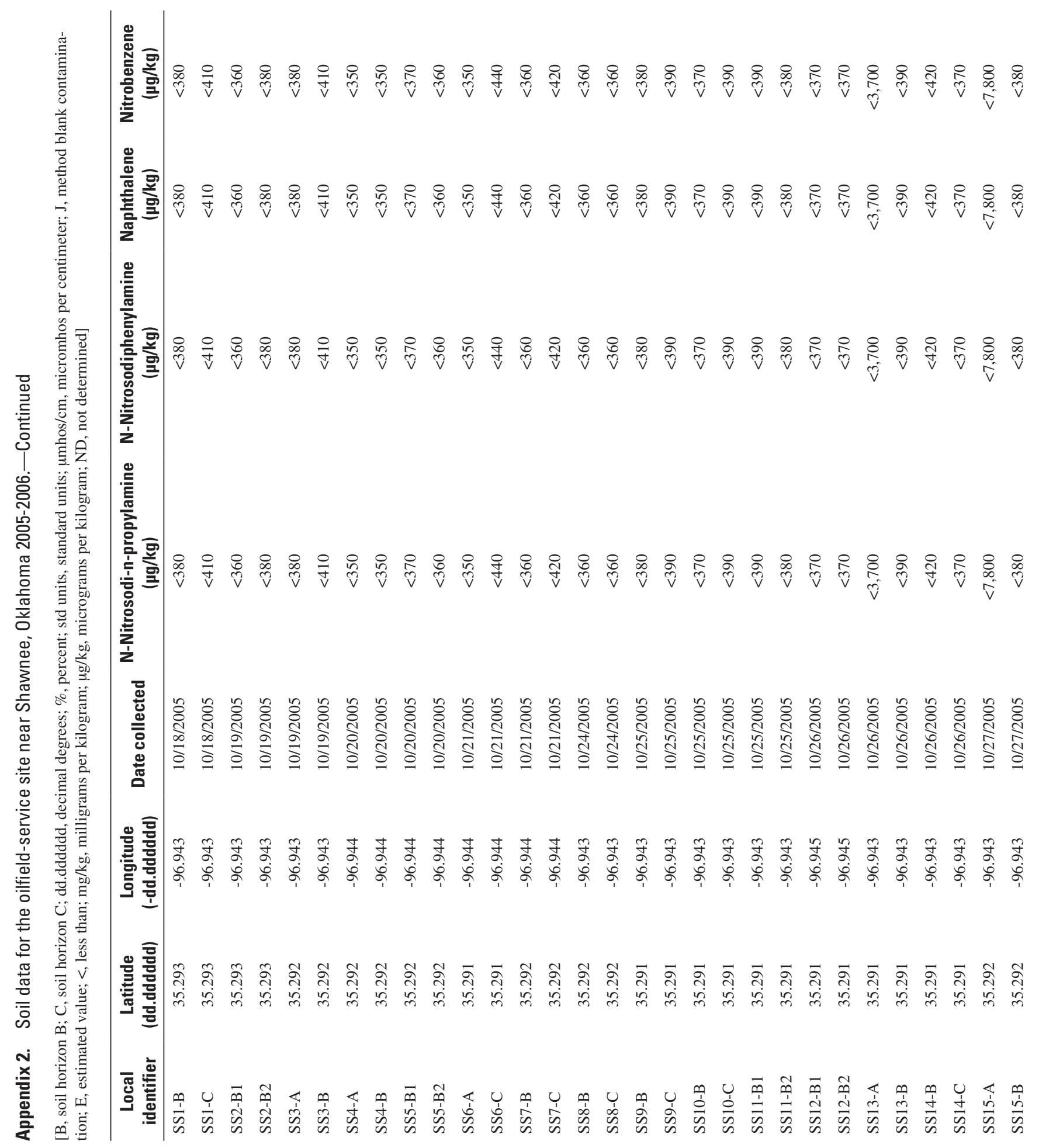




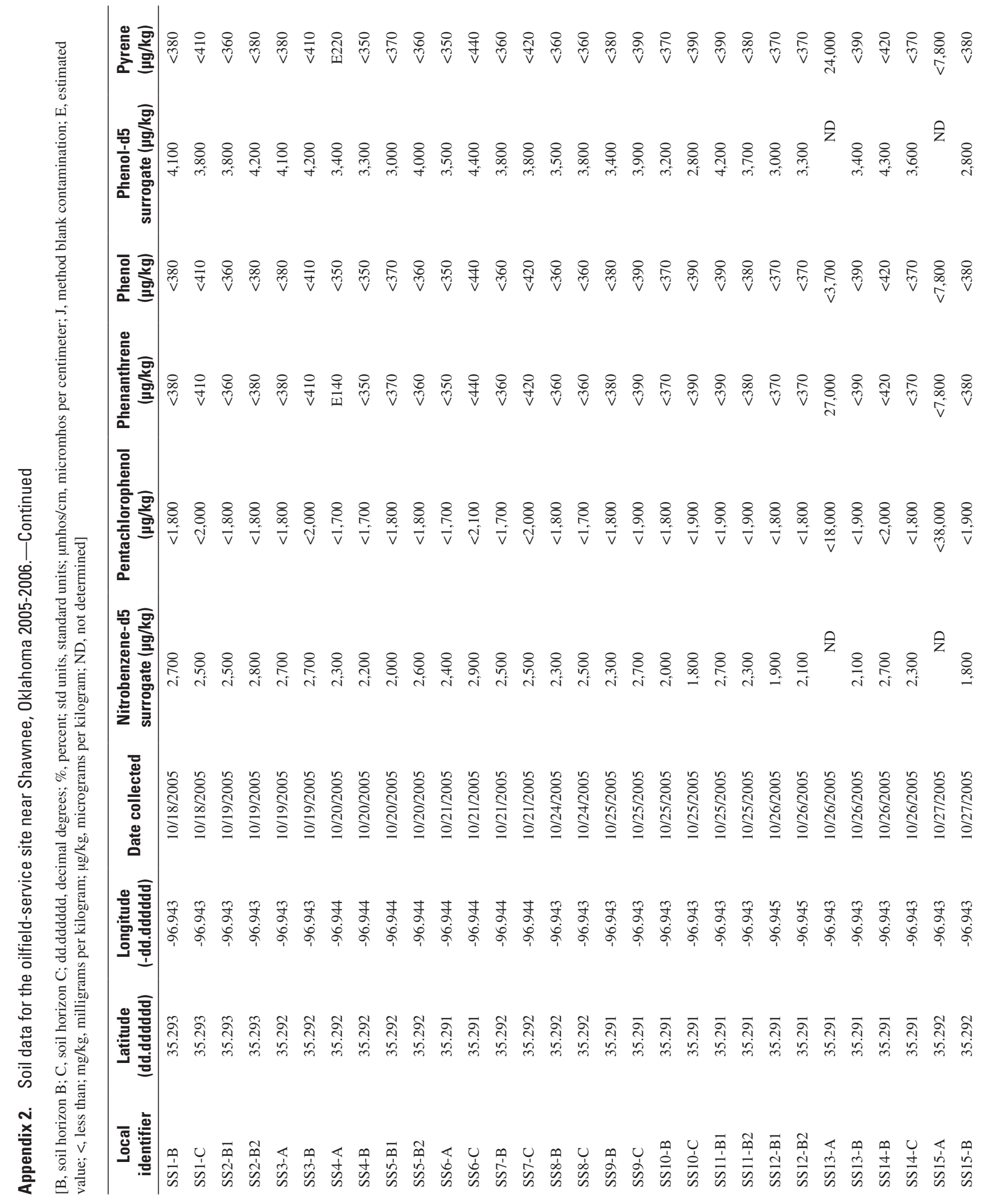




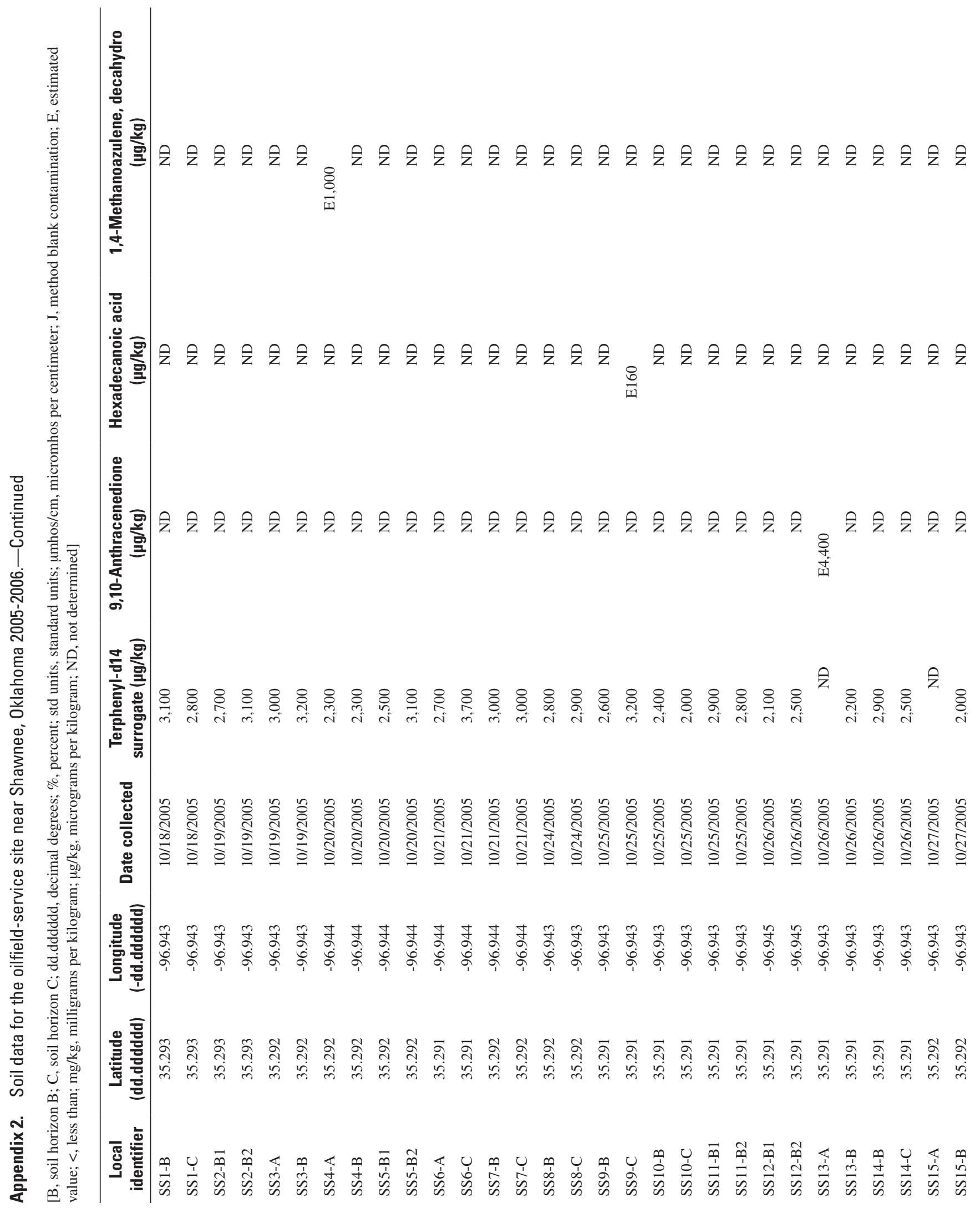




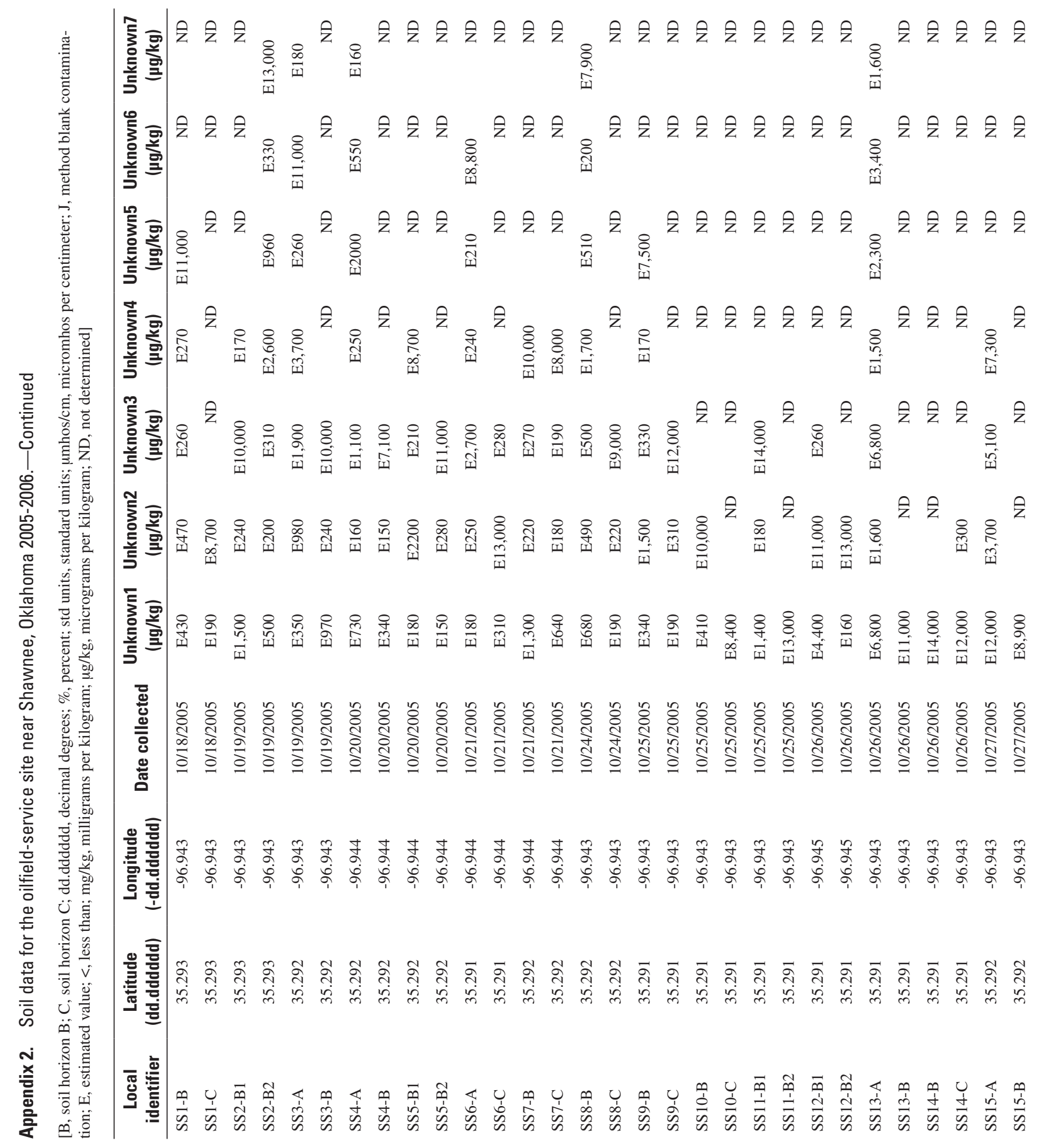




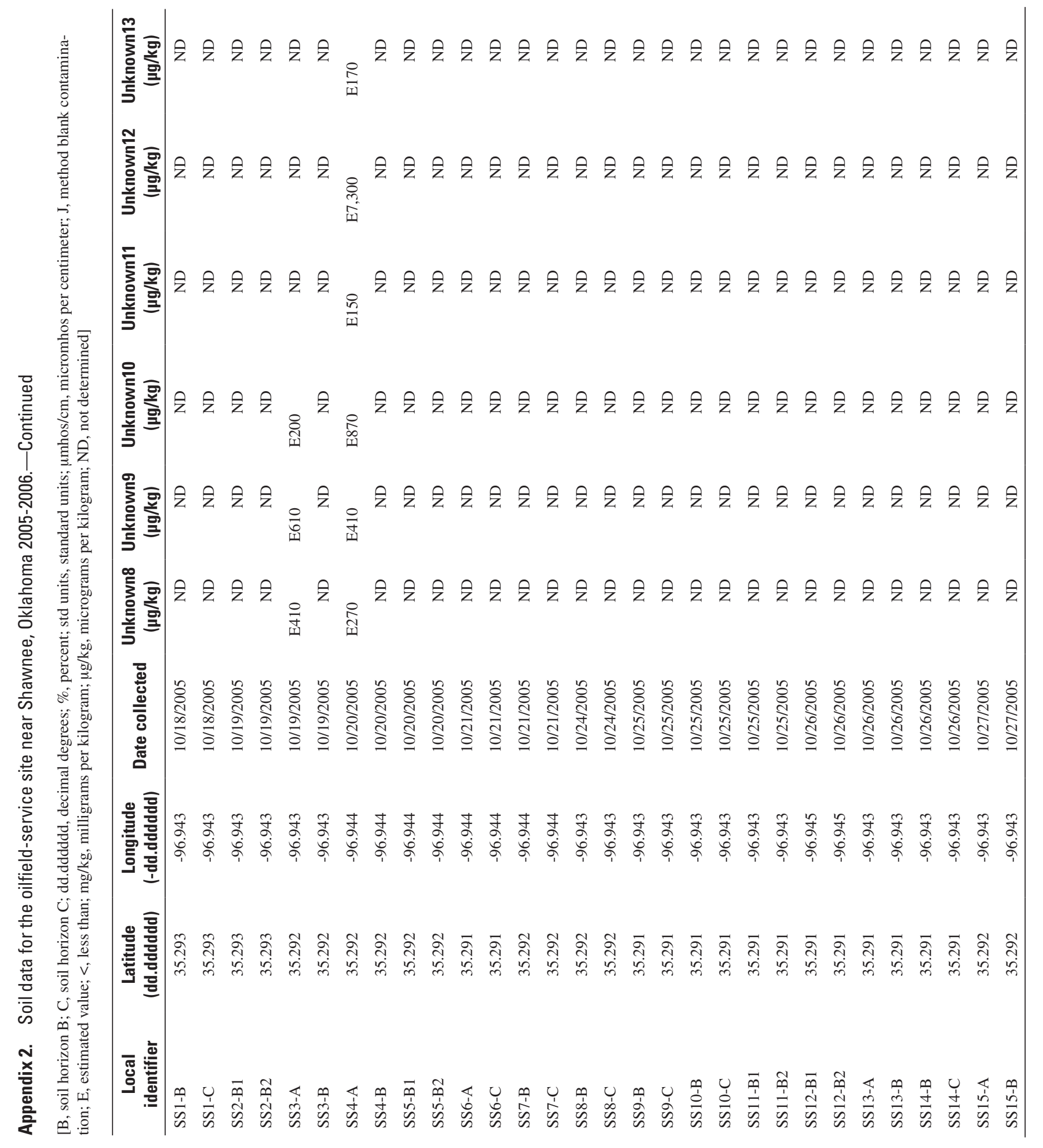




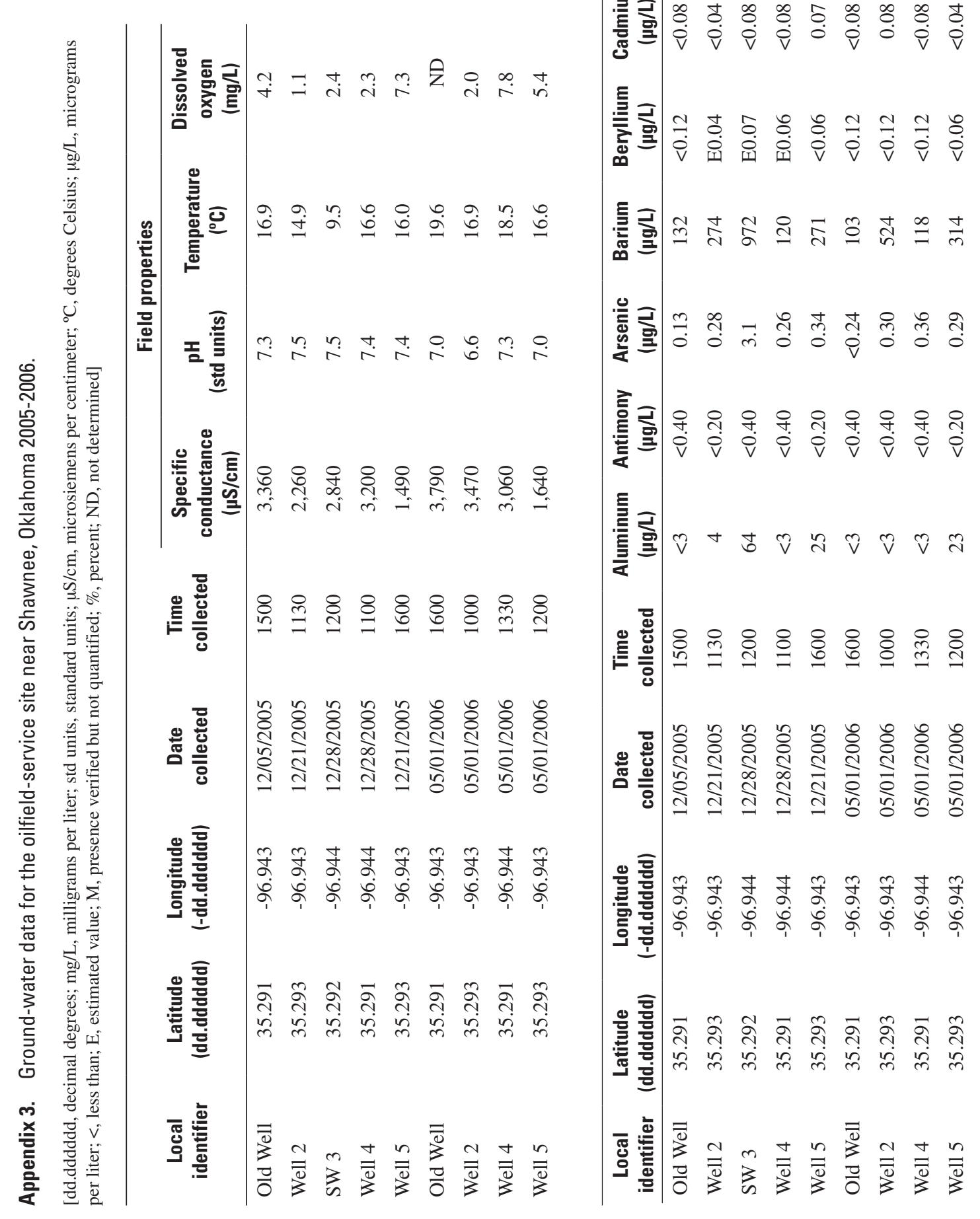




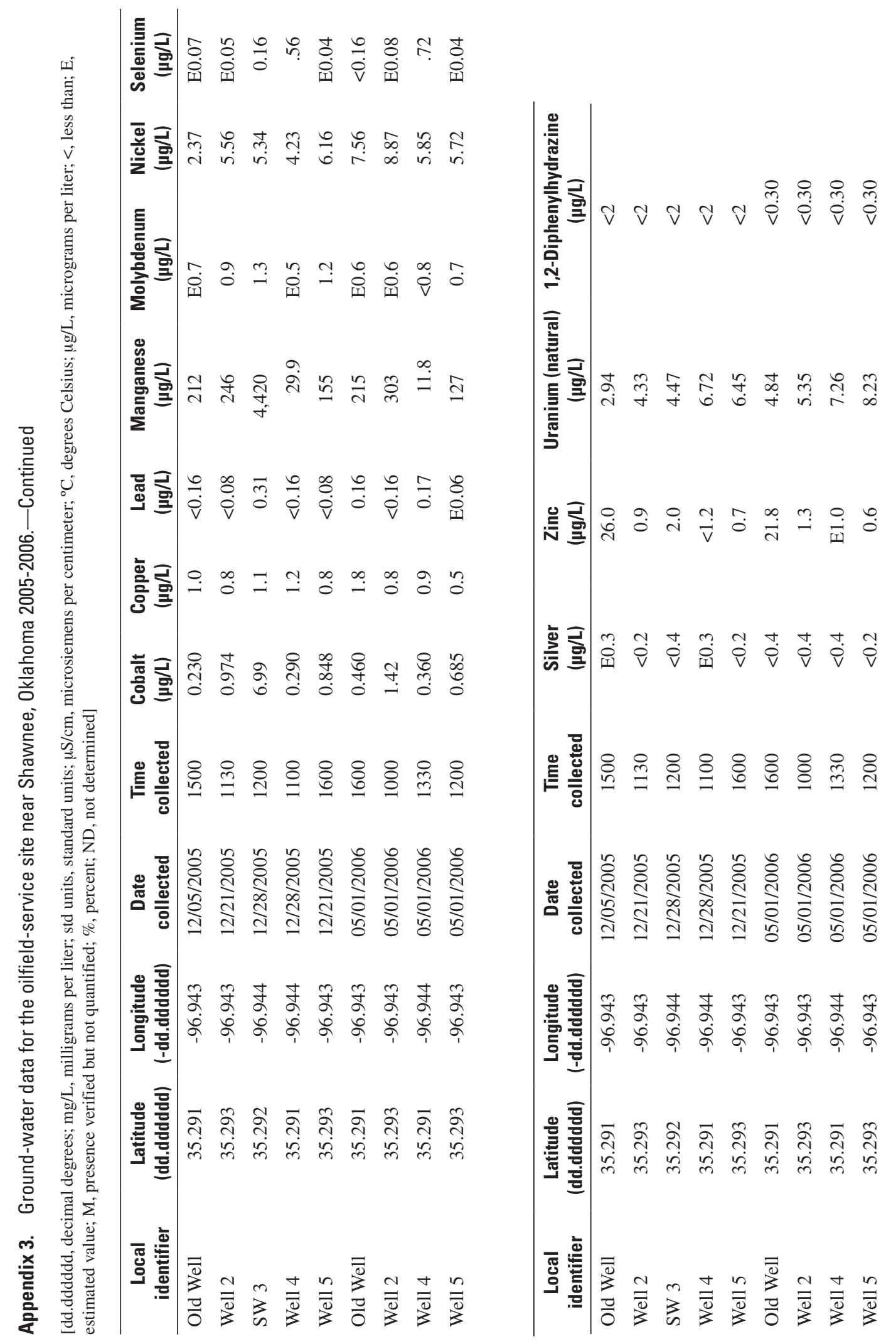




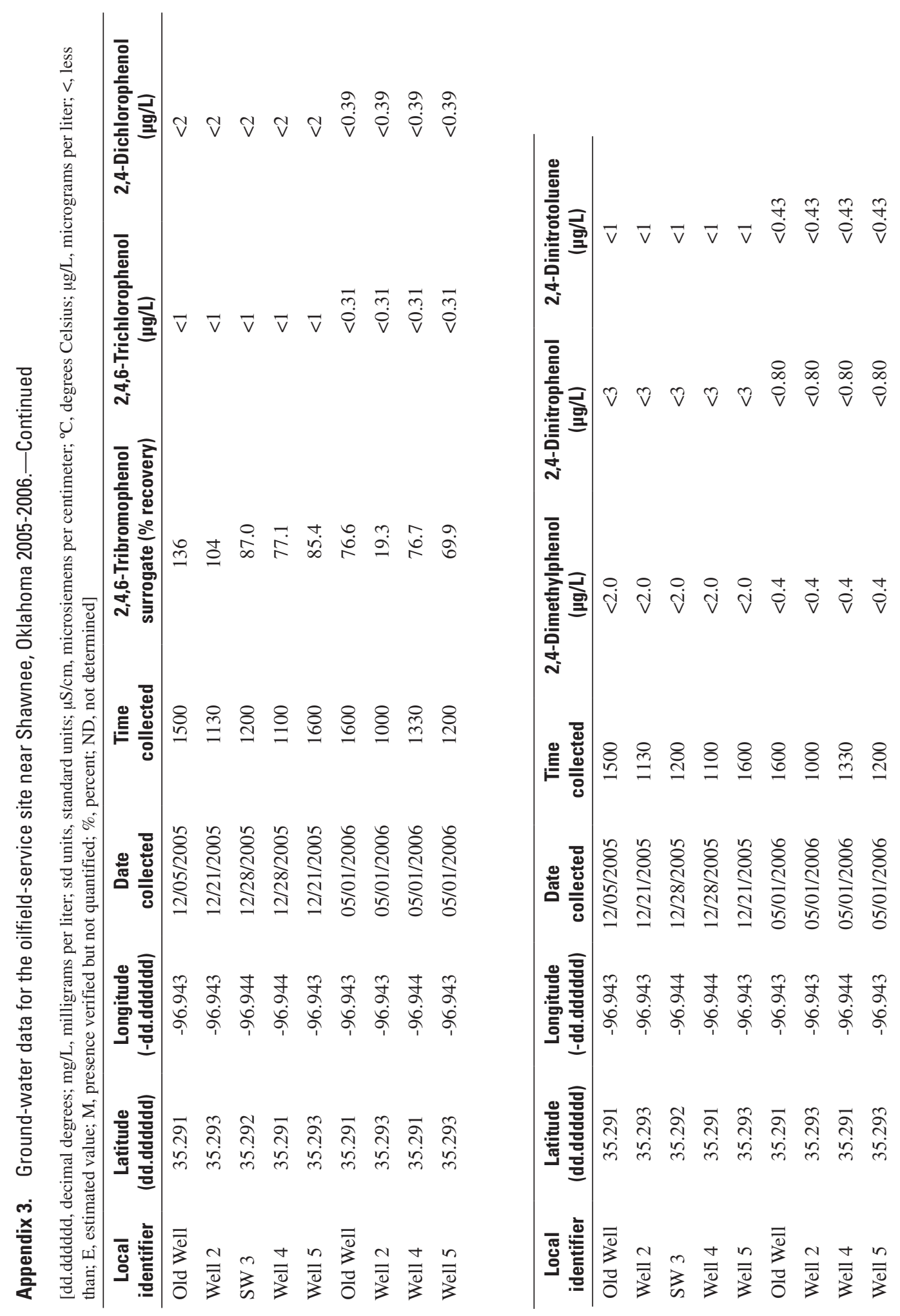



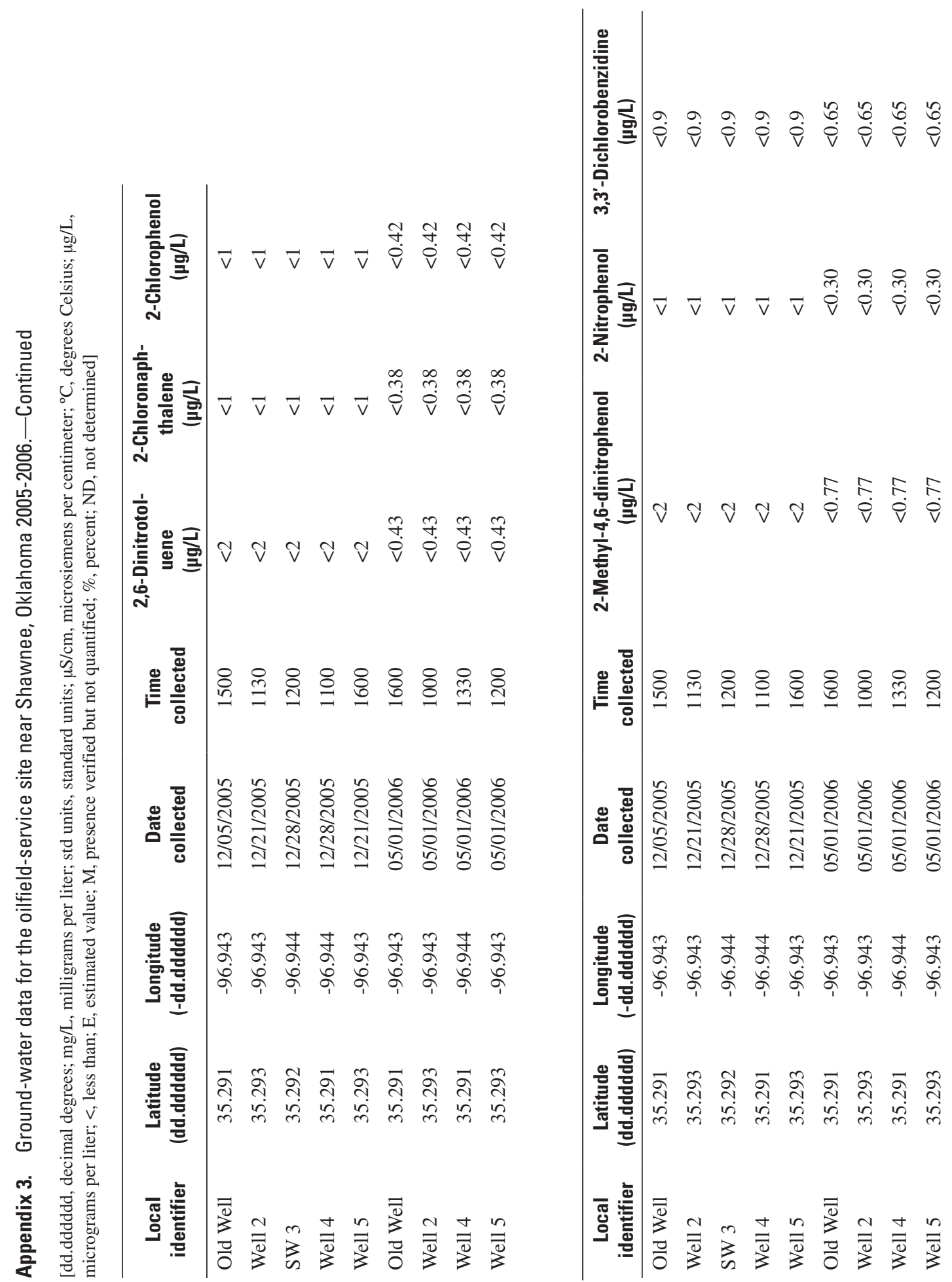


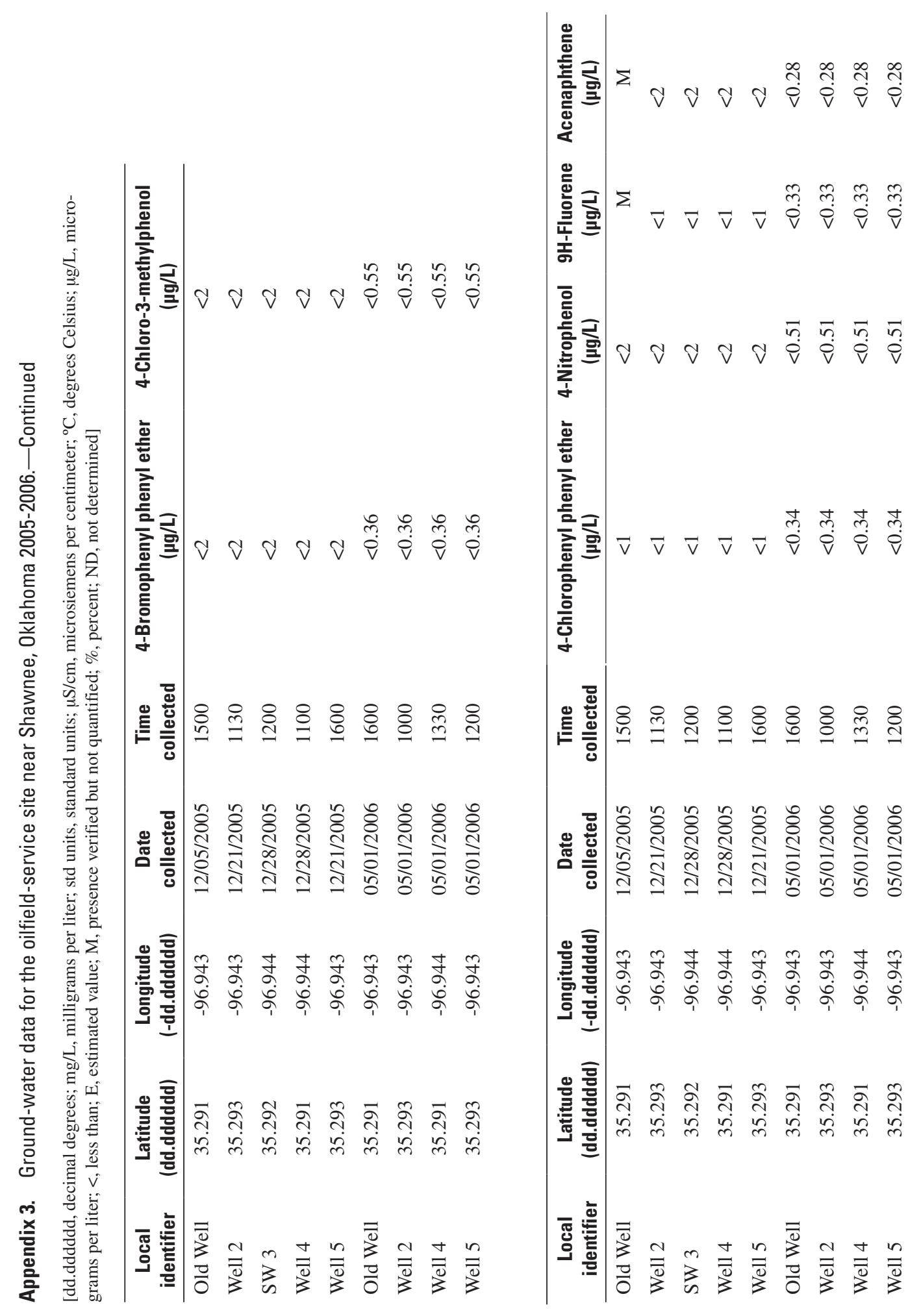



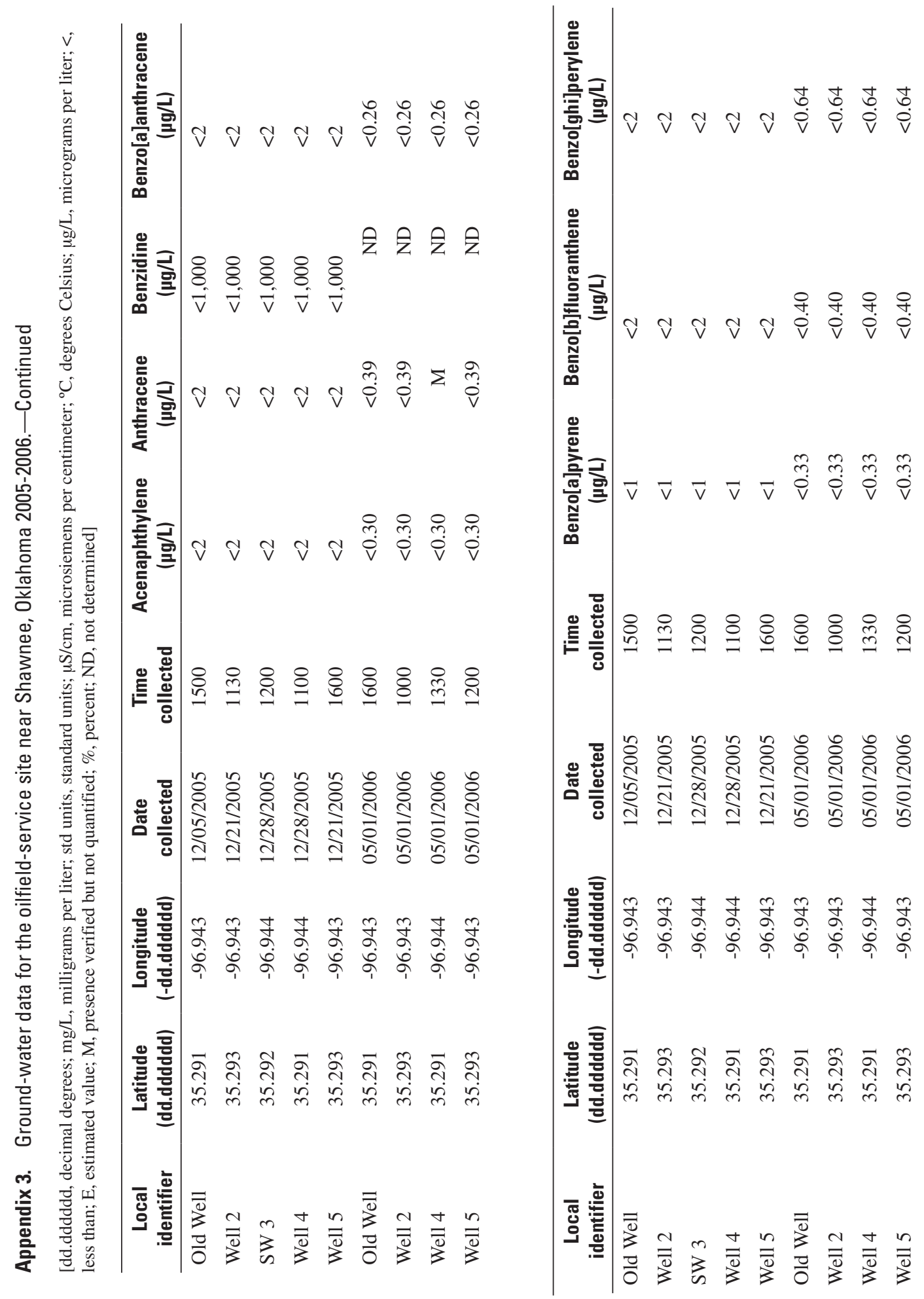


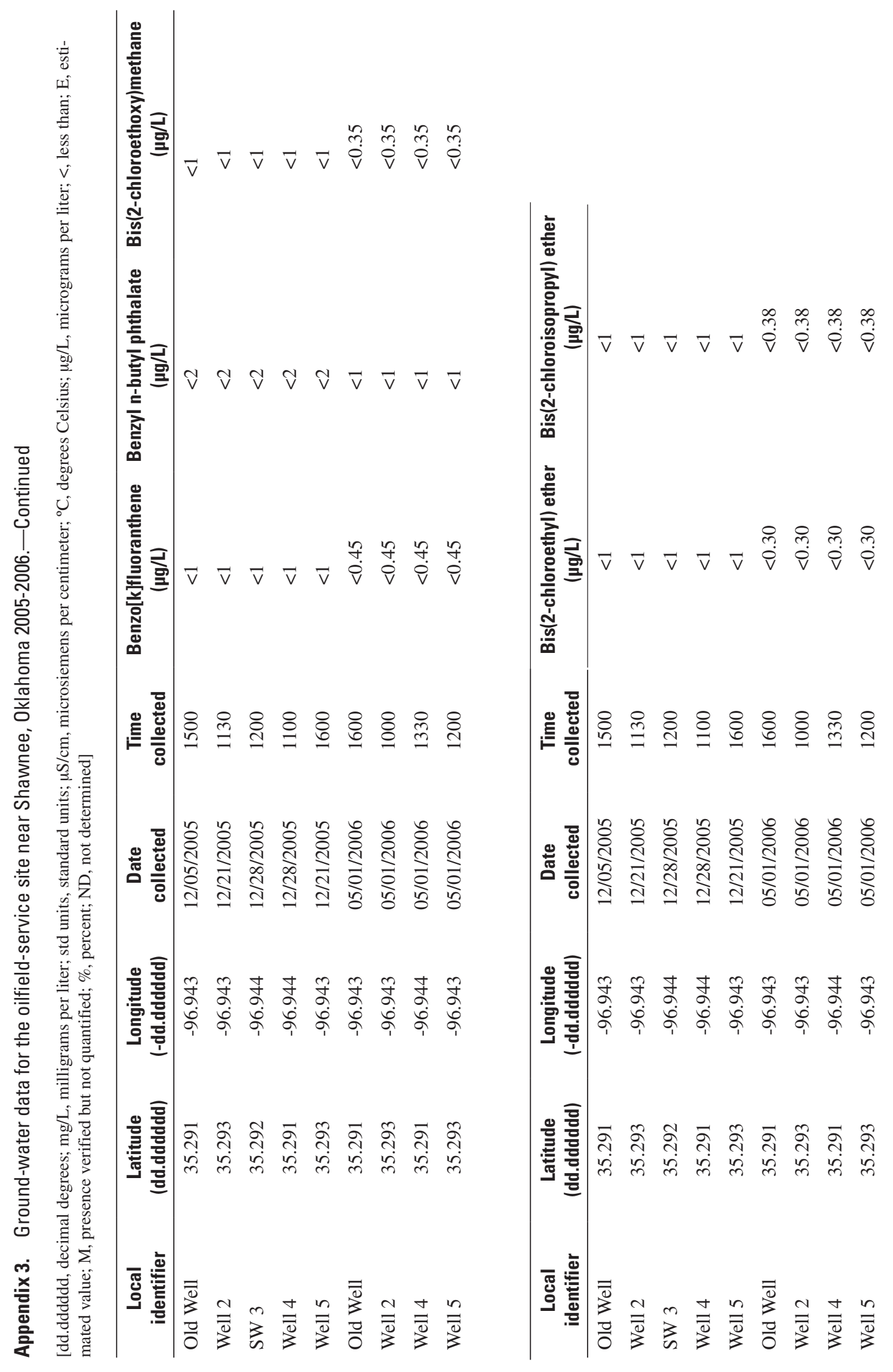




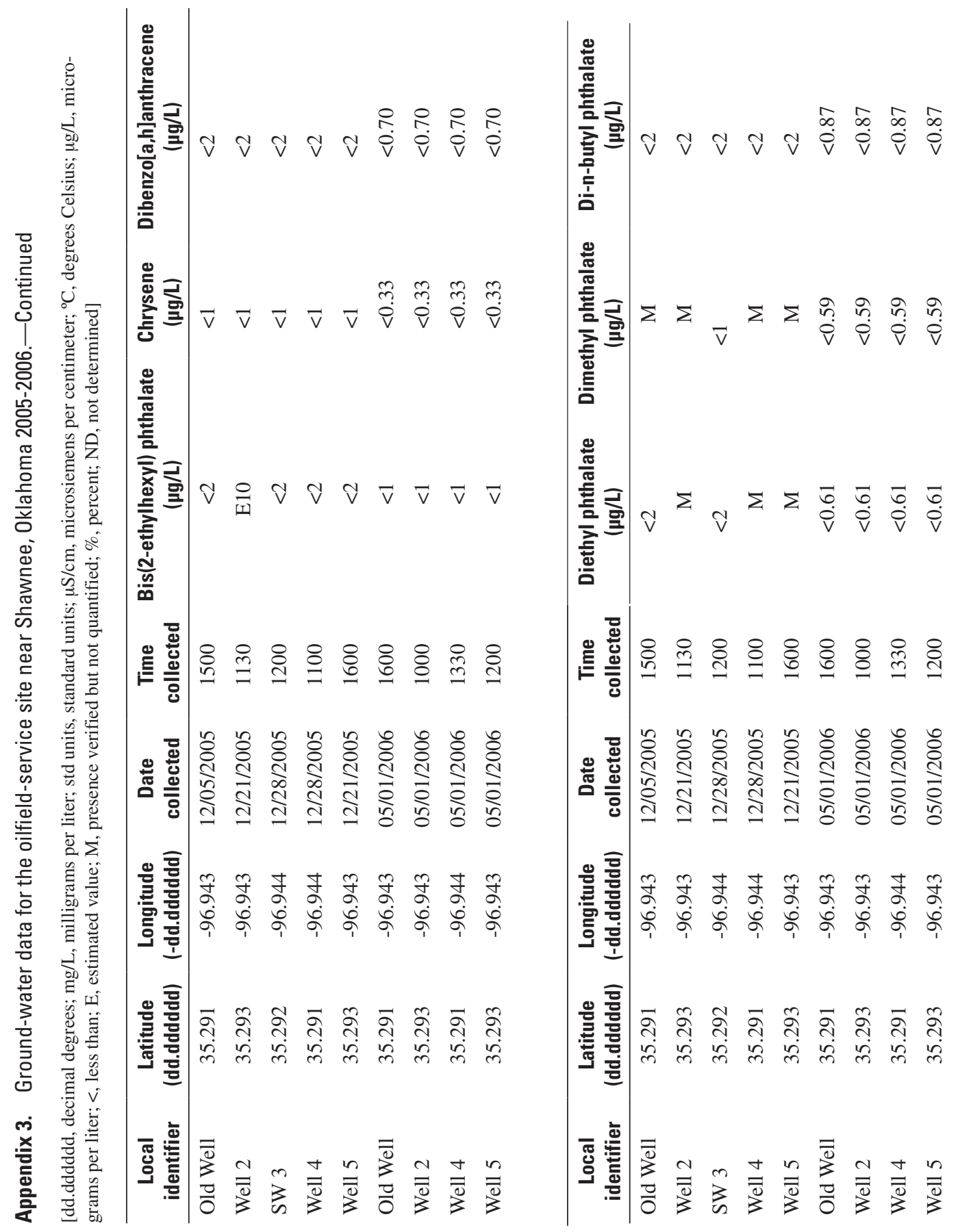



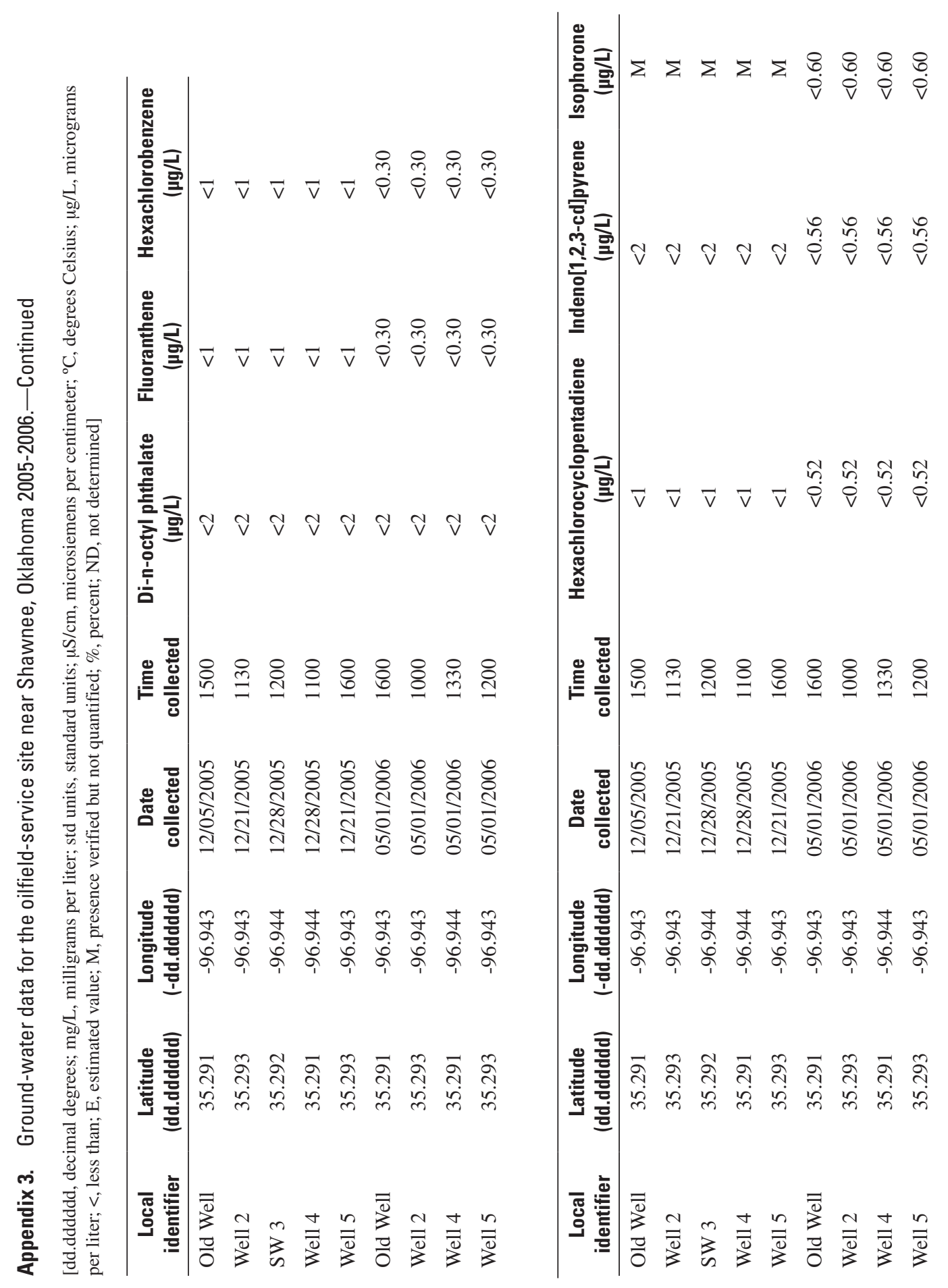


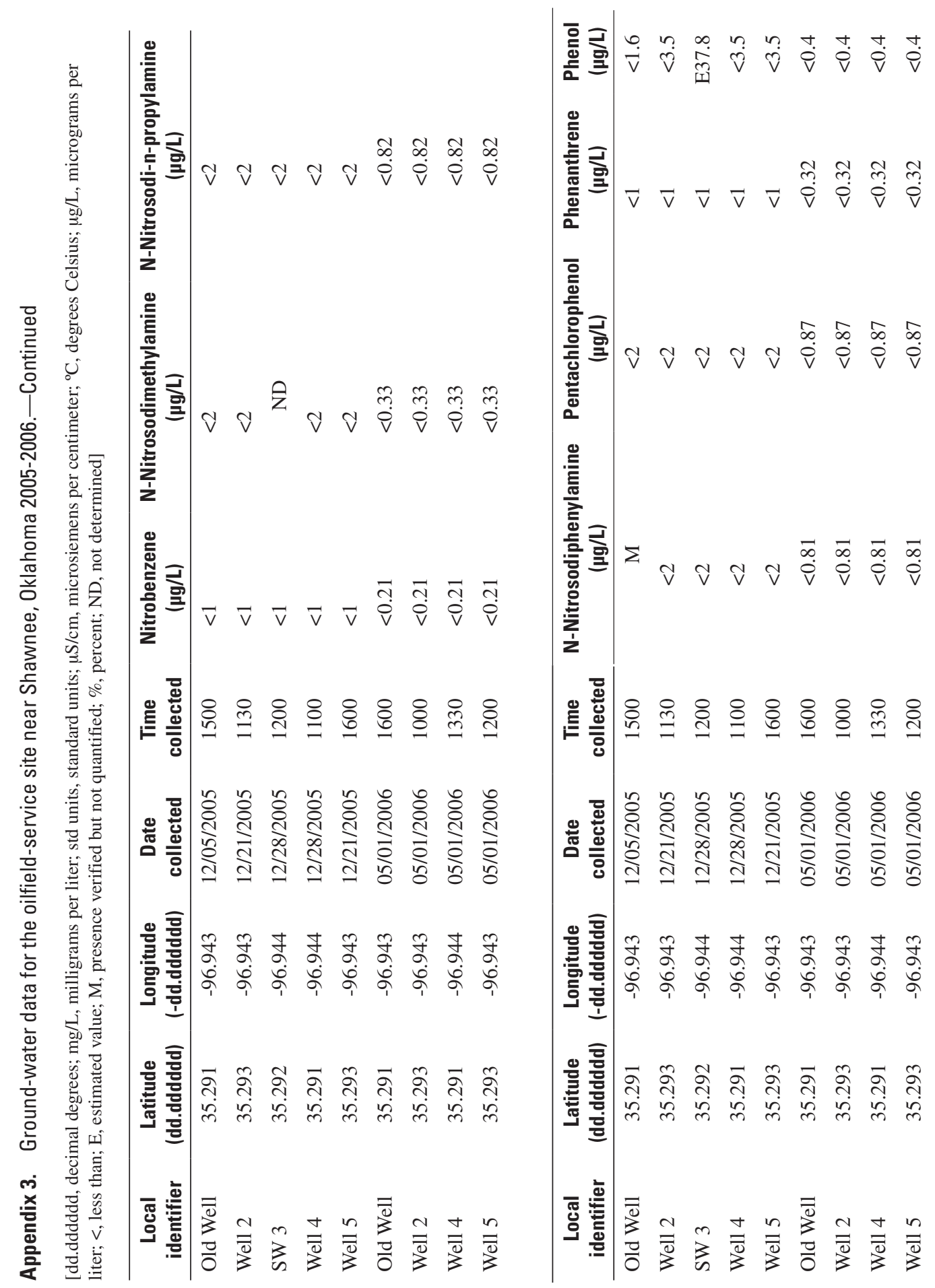



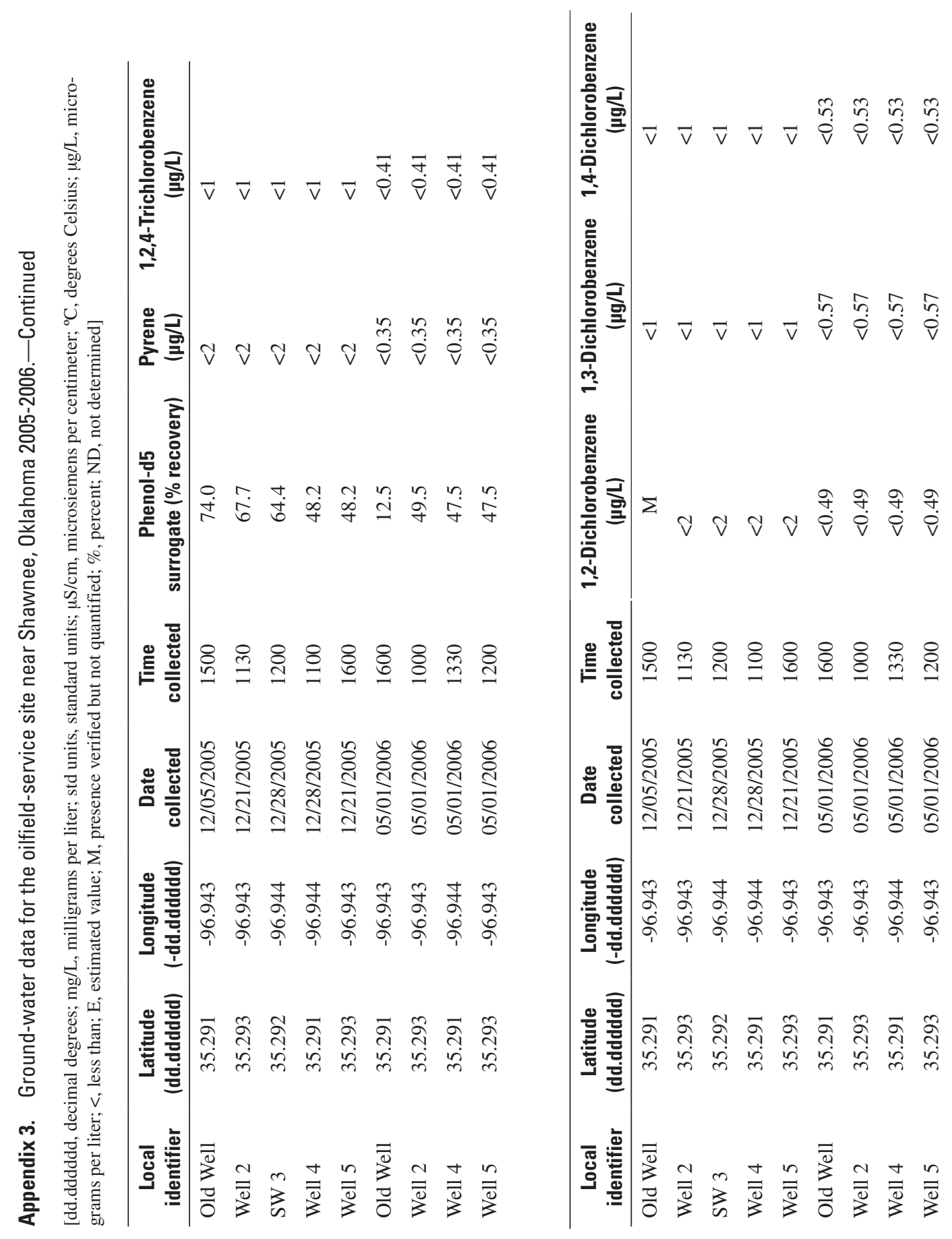


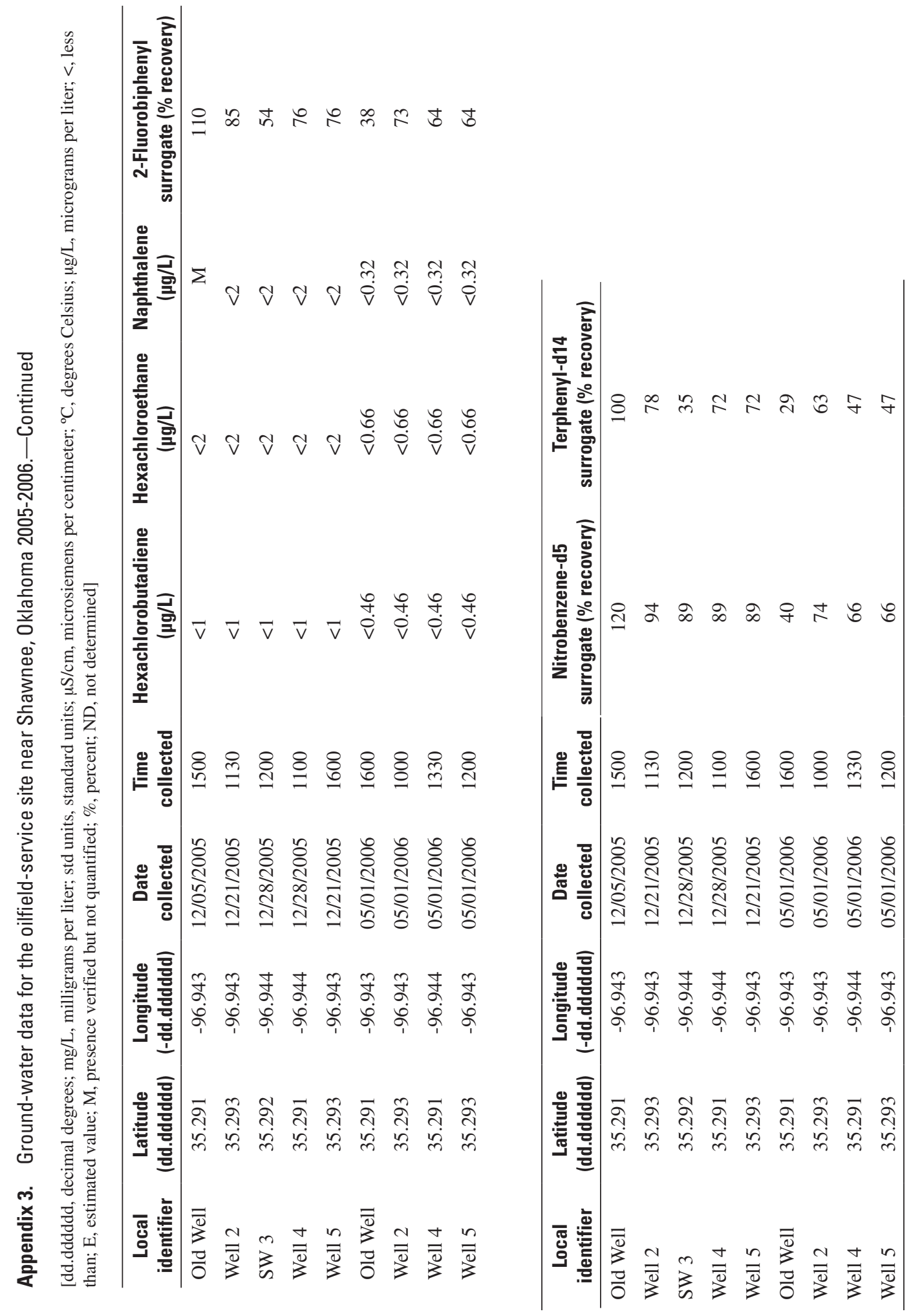




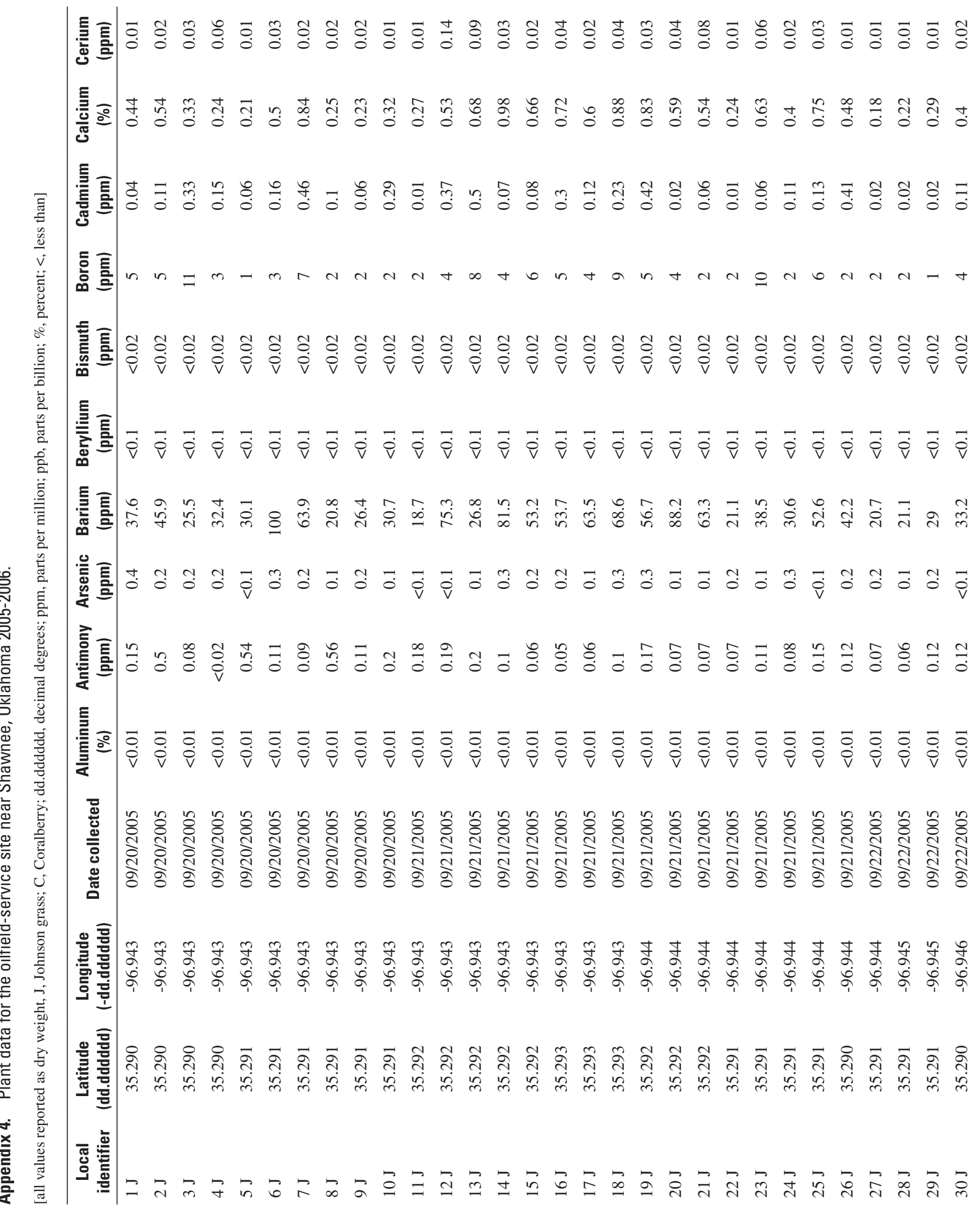




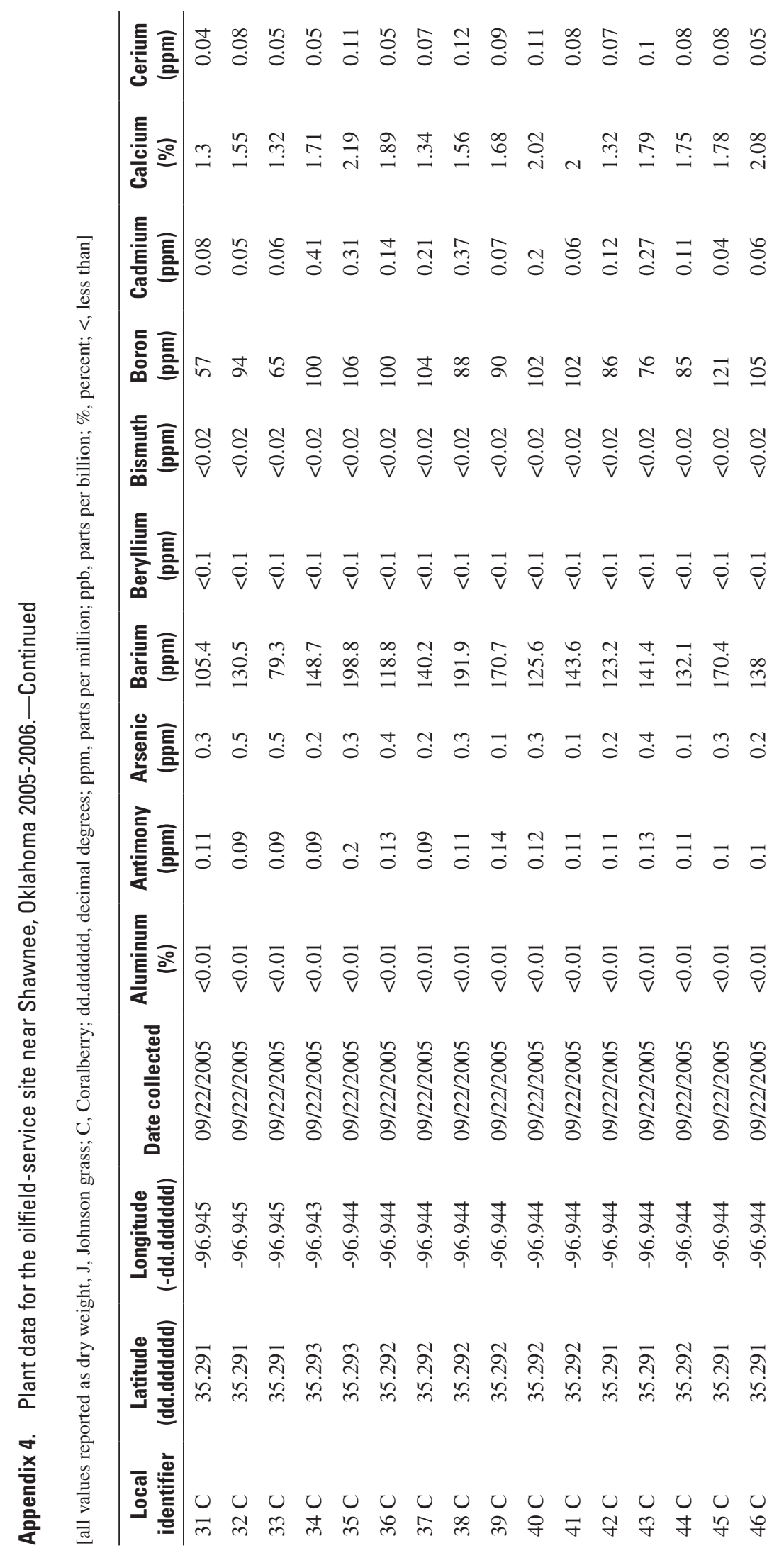




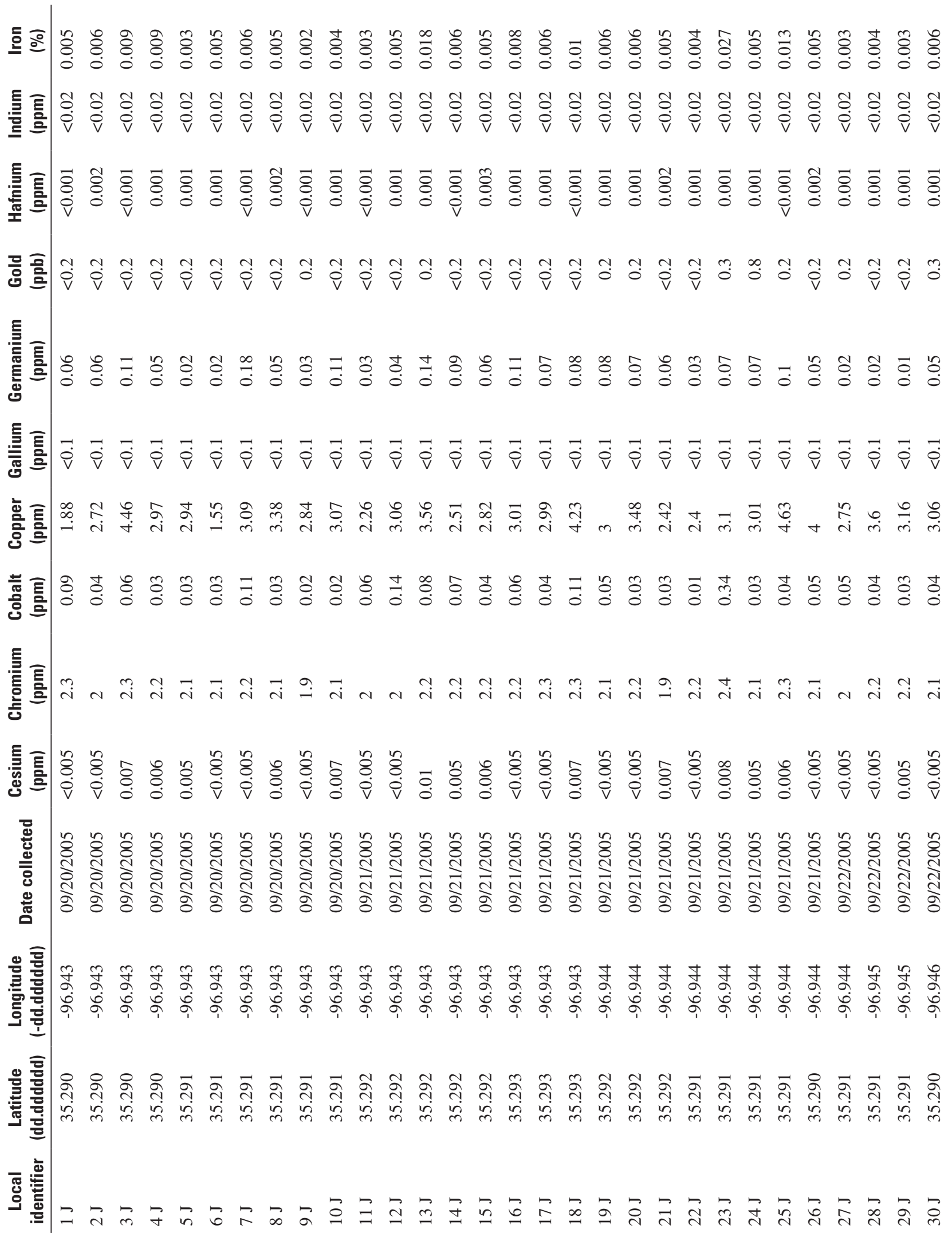




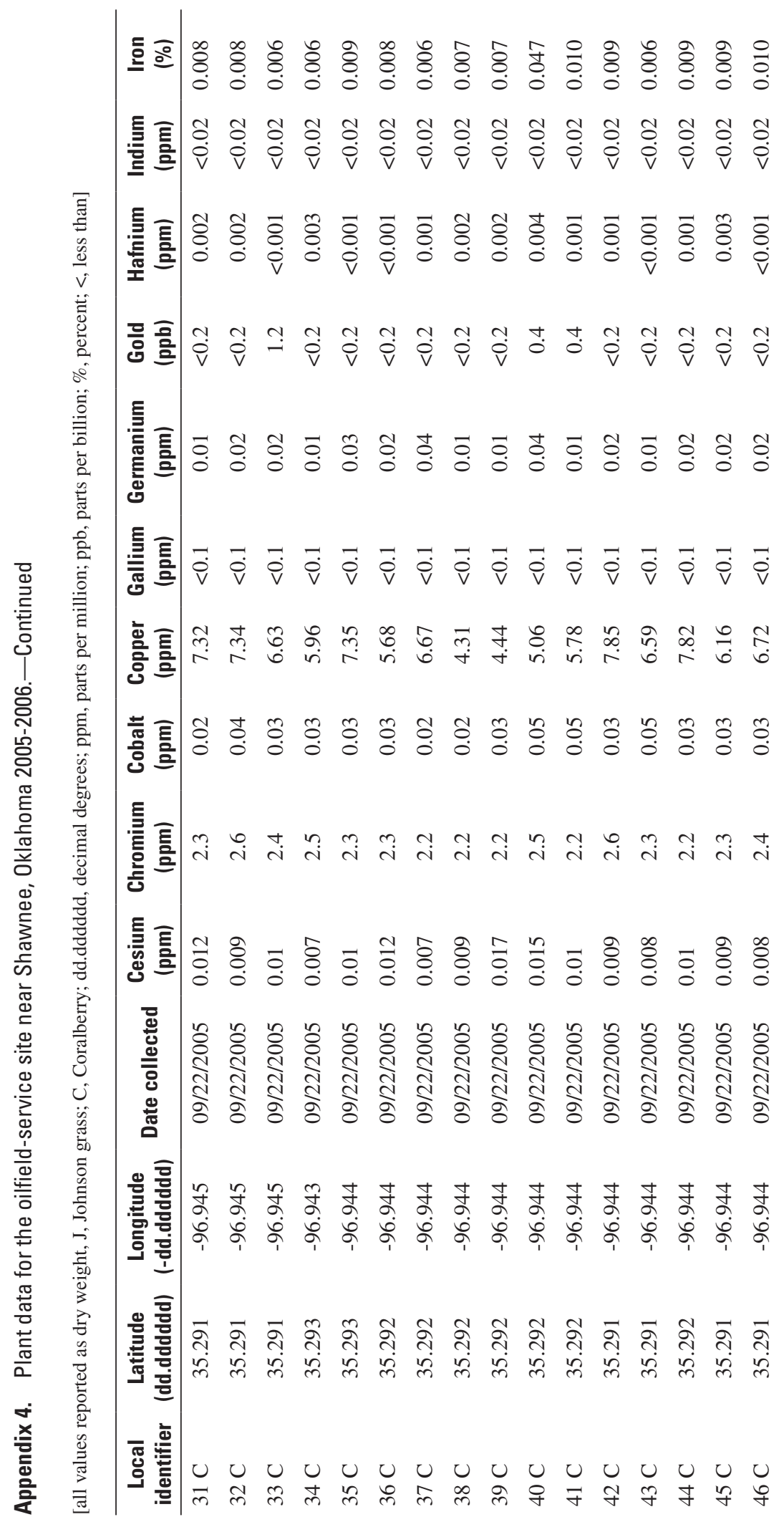




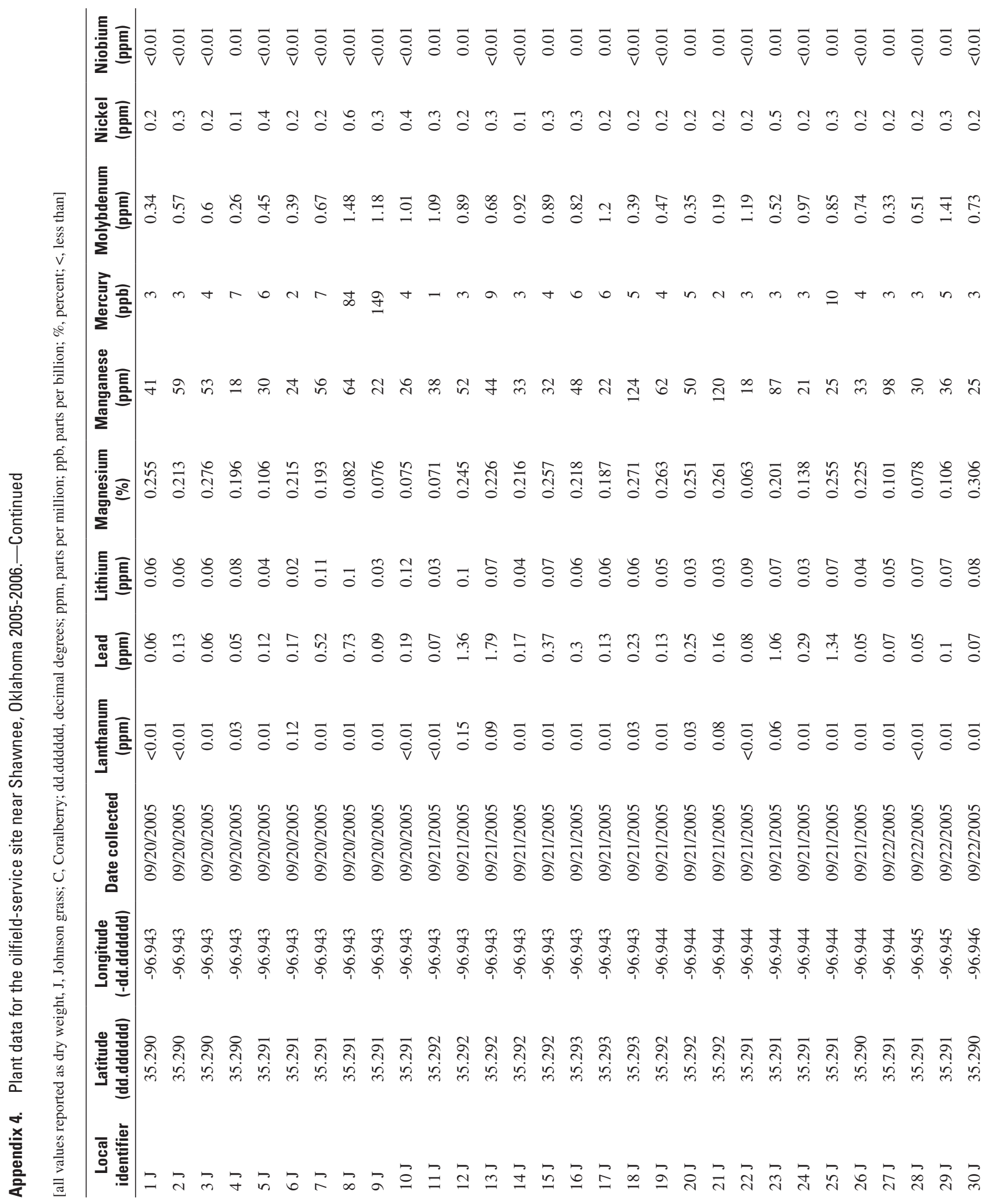




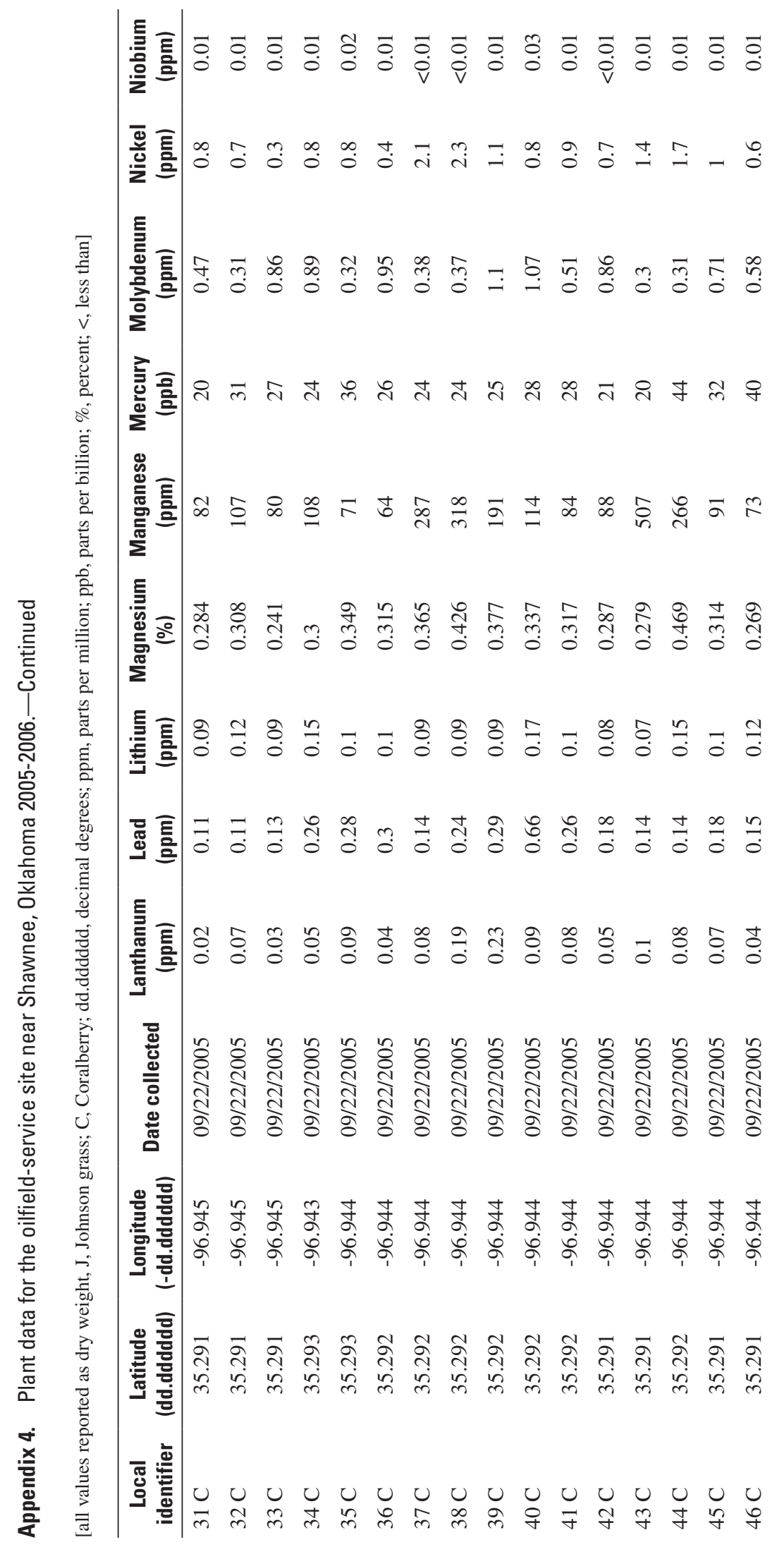




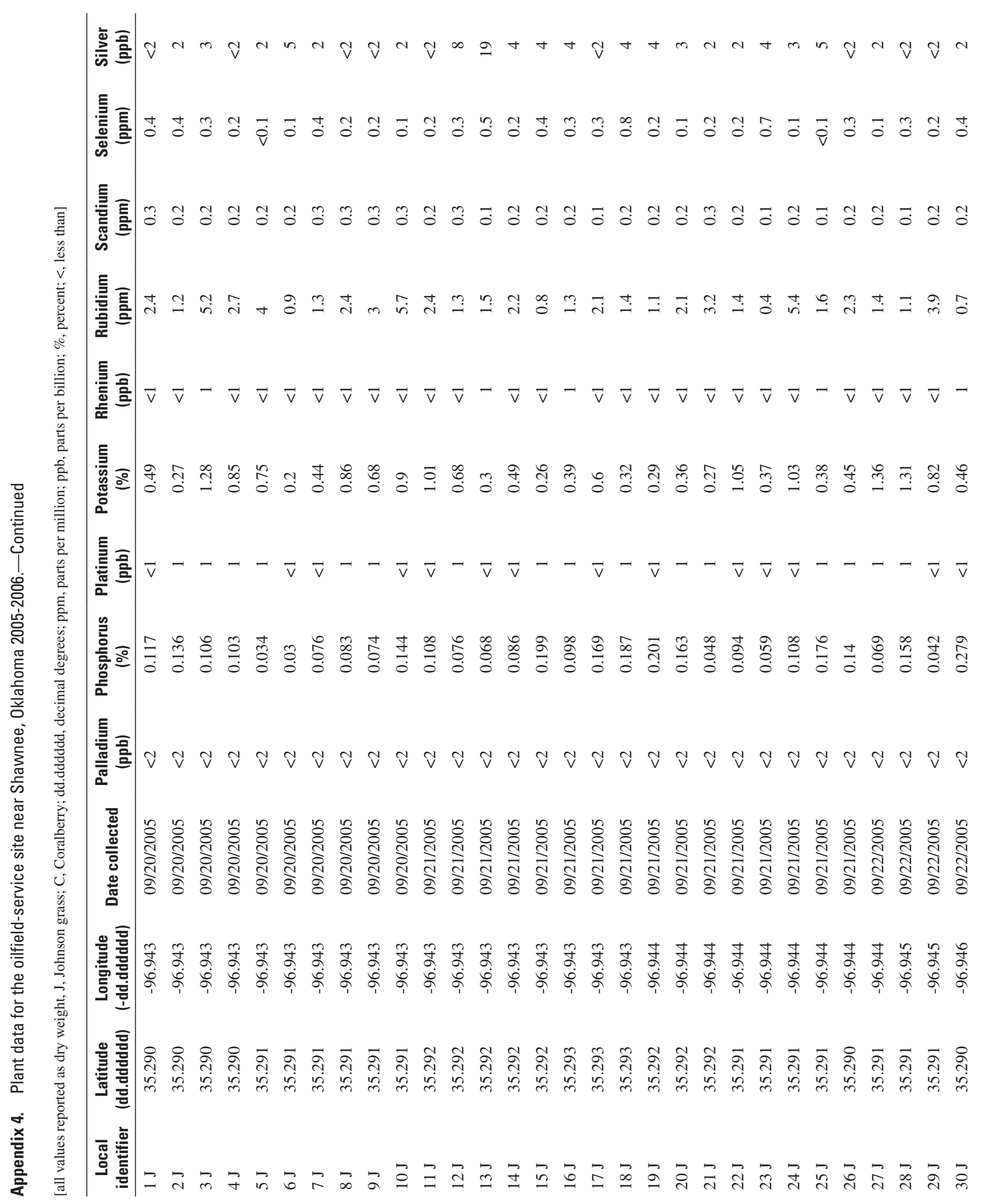




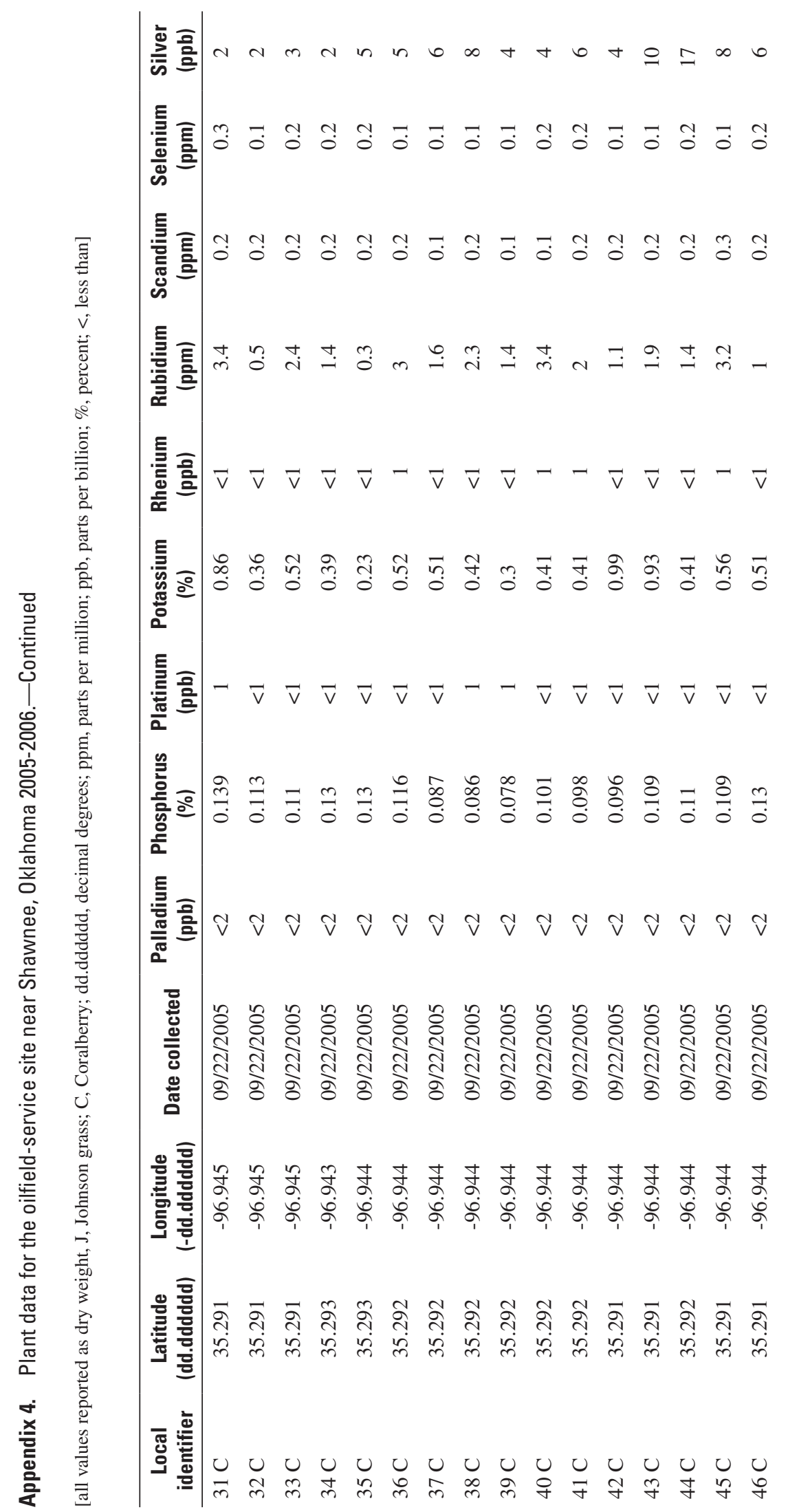




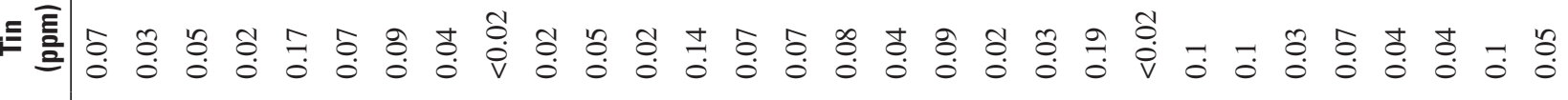

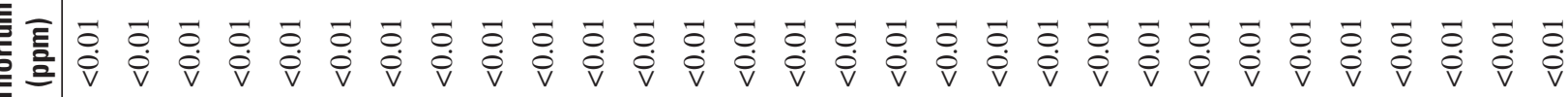

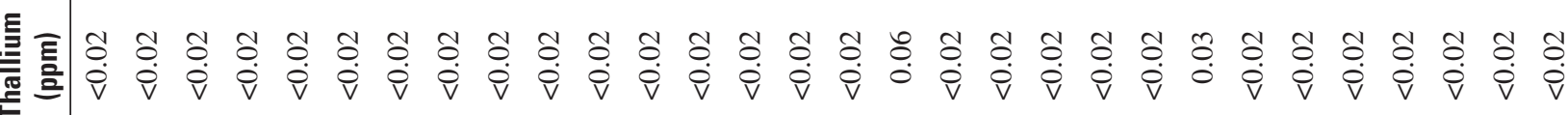

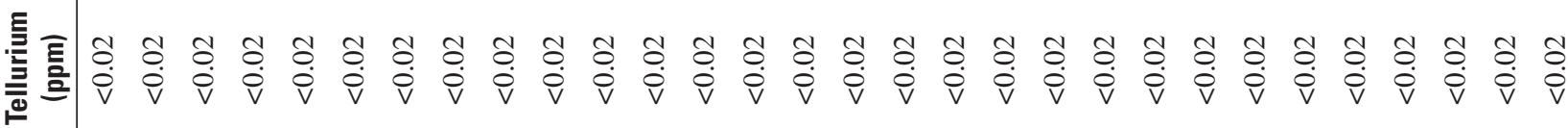

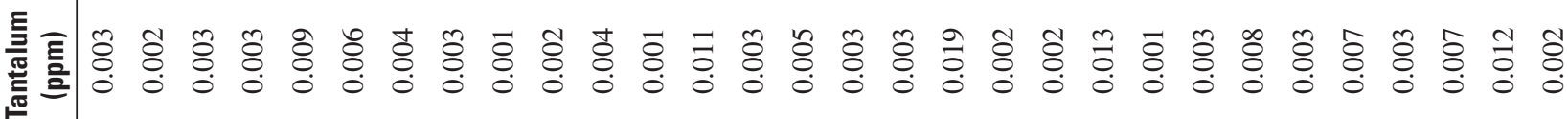
䩧 衰言 ஓं

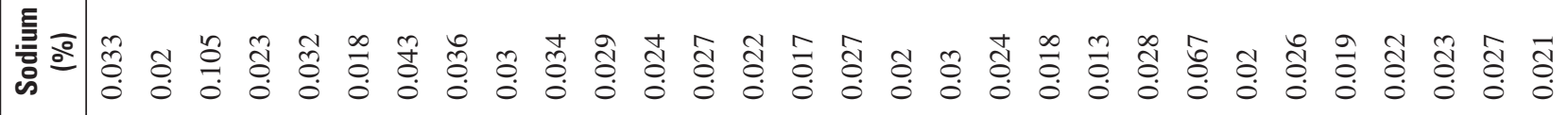

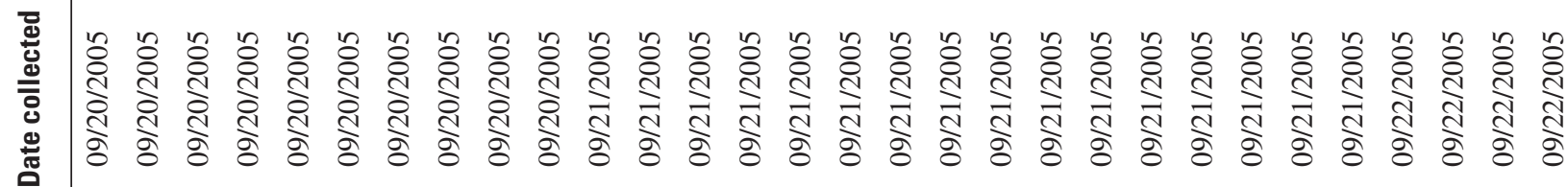

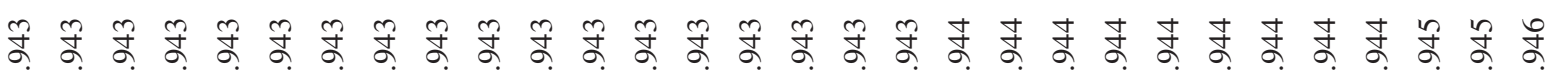

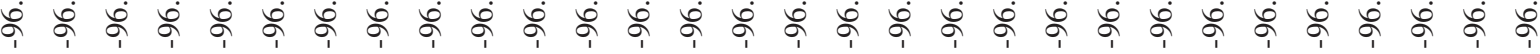

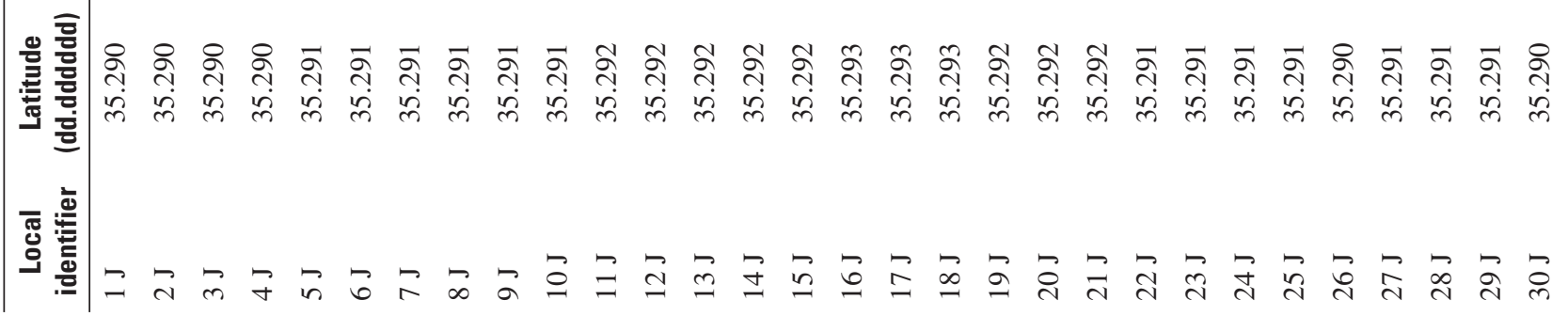




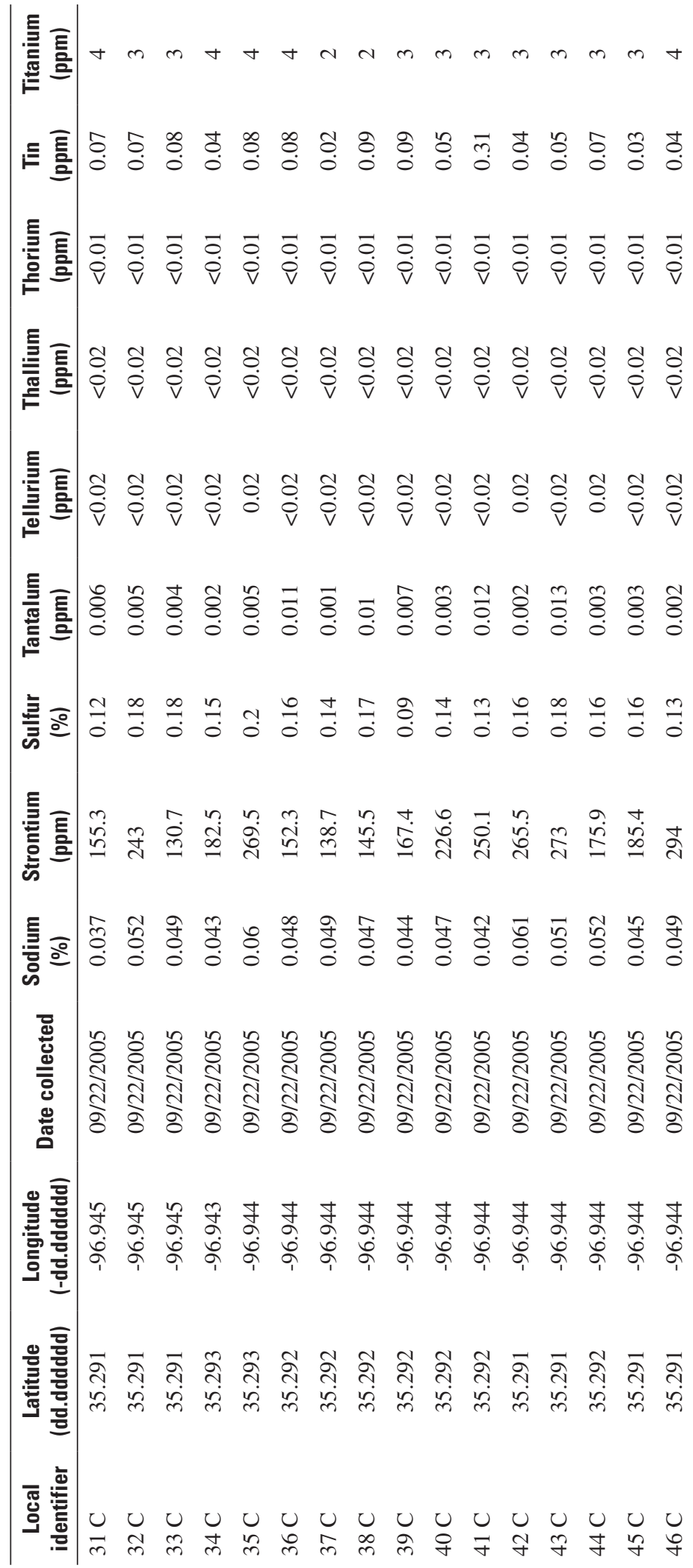




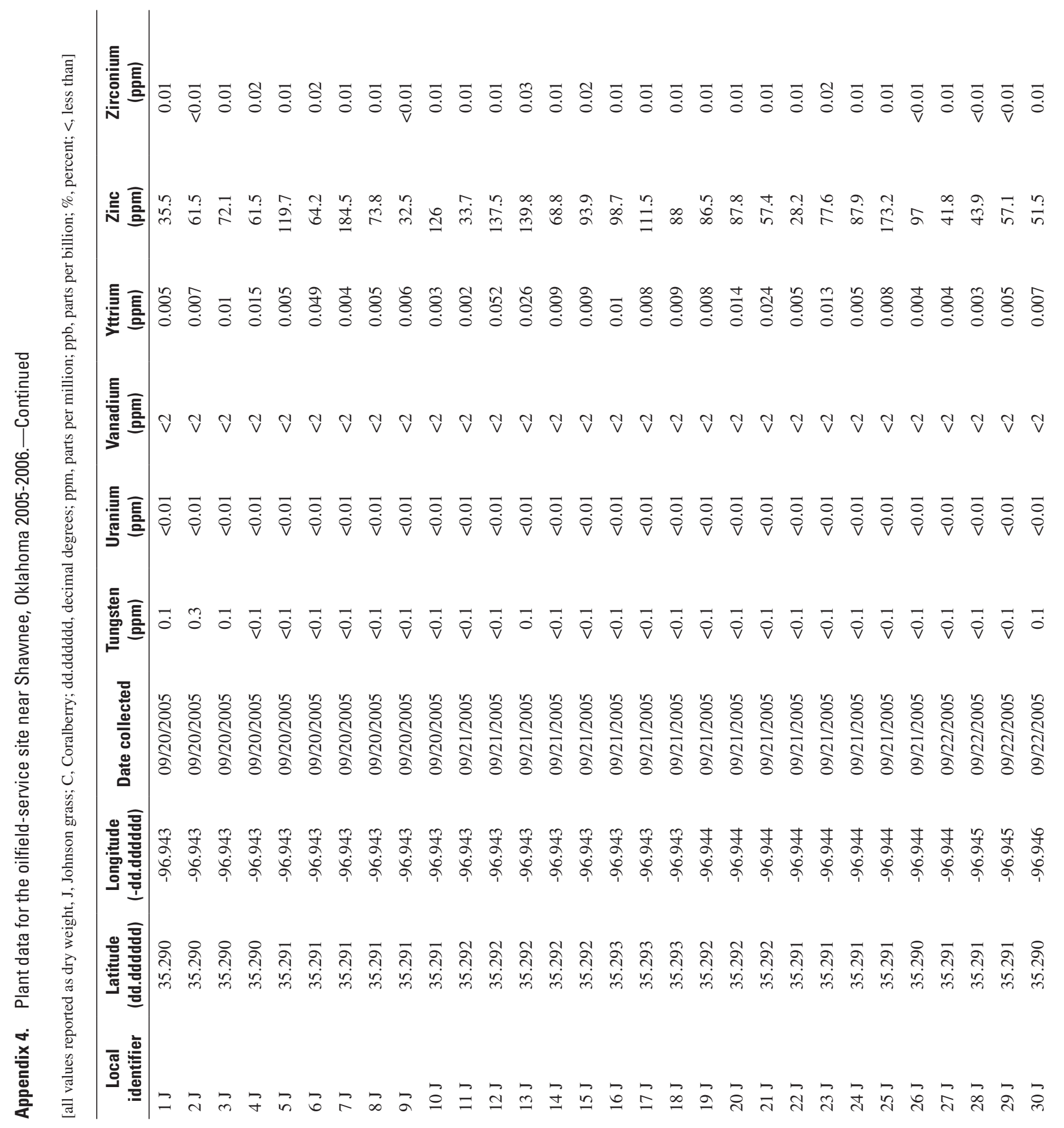




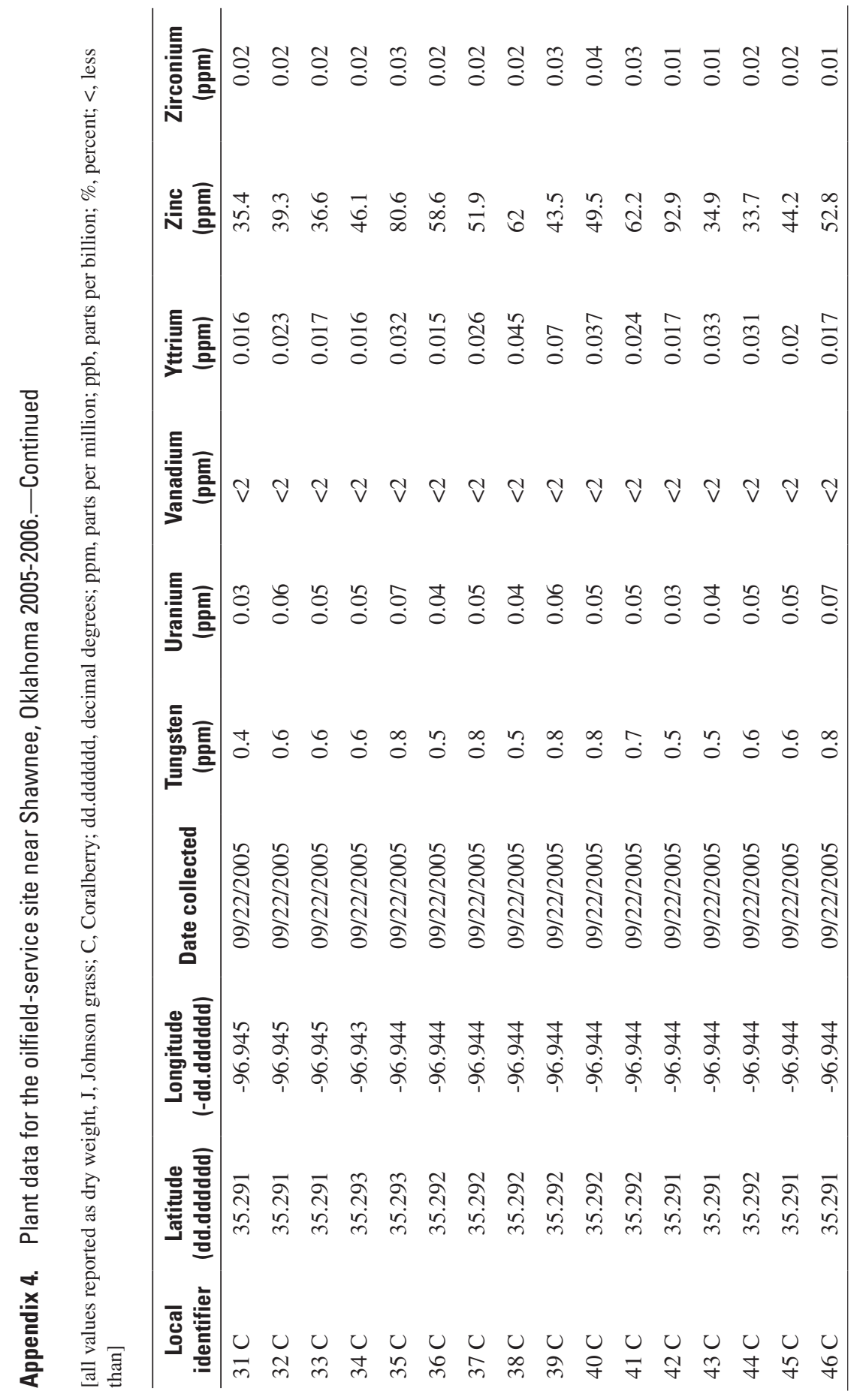

